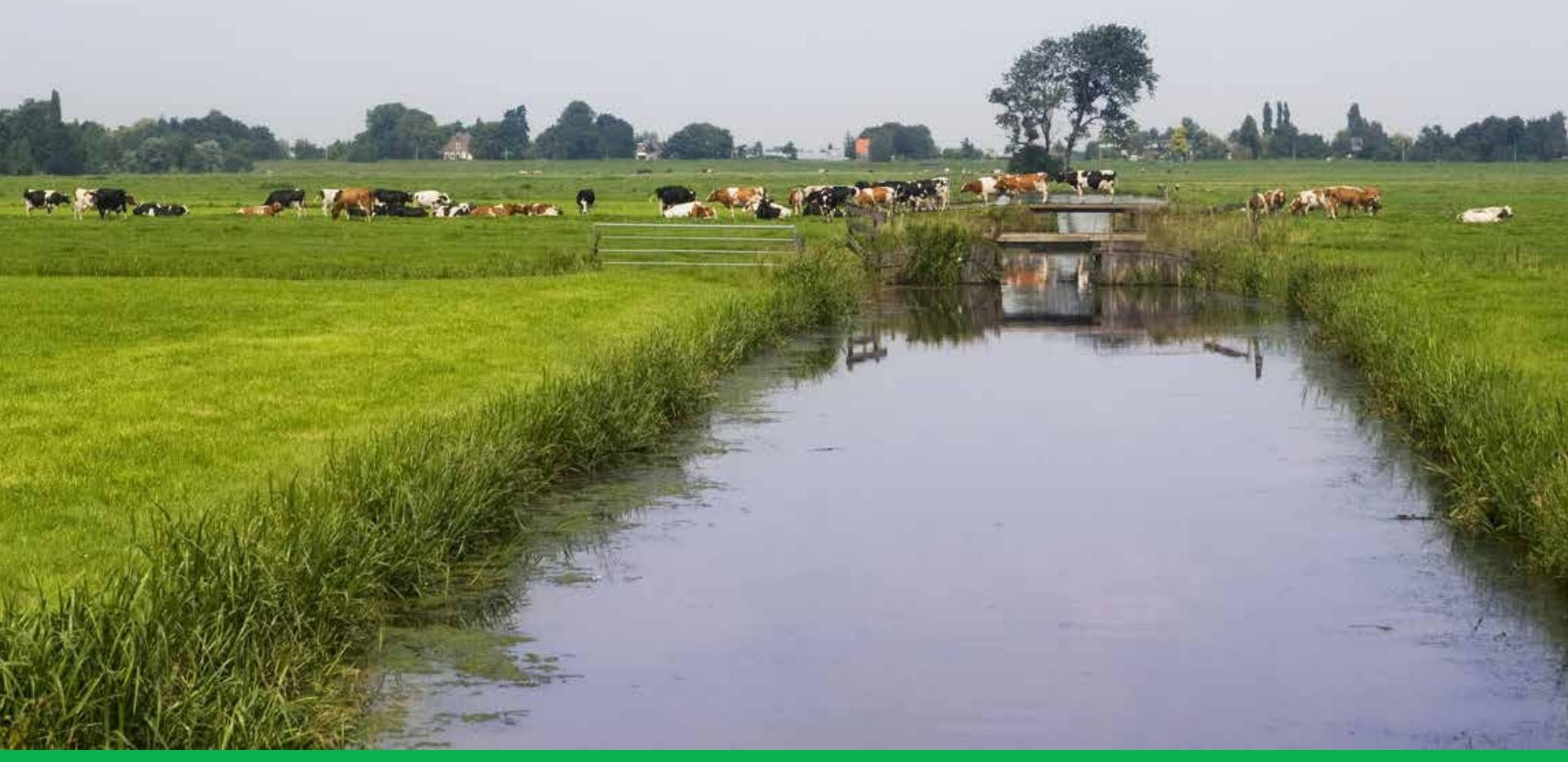

\title{
Financiële prikkels in de landbouw voor verbetering van de waterkwaliteit
}

Ron Bergevoet, Nico Bondt, Carolien de Lauwere, Jan Buurma, Vincent Linderhof en Piet Rijk

LE I

WAGENINGEN UR 


\section{Financiële prikkels in de landbouw voor verbetering van de waterkwaliteit}

Ron Bergevoet, Nico Bondt, Carolien de Lauwere, Jan Buurma, Vincent Linderhof en Piet Rijk

Dit onderzoek is uitgevoerd door LEI Wageningen UR in opdracht van en gefinancierd door het ministerie van Infrastructuur \& Milieu.

LEI Wageningen UR

Wageningen, april 2016

RAPPORT

LEI 2016-033

ISBN 978-94-6257-779-4 
Bergevoet, Ron, Nico Bondt, Carolien de Lauwere, Jan Buurma, Vincent Linderhof en Piet Rijk, 2016. Financiële prikkels in de landbouw voor verbetering van de waterkwaliteit. Wageningen, LEI

Wageningen UR (University \& Research centre), LEI Report 2016-033. 90 blz.; 8 fig.; 19 tab.; 33 ref.

In de agrarische ketens zijn al veel beleidsinstrumenten ingezet om de uitstoot van vervuilende stoffen naar het water te beperken. Echter, slechts weinig van de bestaande instrumenten zijn economische instrumenten en weinig is gericht op het 'vervuiler betaalt'-principe (zoals gehanteerd in dit onderzoek). Wel maken de land- en tuinbouw in het algemeen, en specifieke sectoren in het bijzonder, kosten om de emissie van schadelijke stoffen te beperken. Er zijn mogelijkheden om met nieuwe instrumenten meer invulling te geven aan het 'vervuiler betaalt'-principe. Deze instrumenten kunnen het beste worden ingezet op het bedrijfsniveau en/of bij de afvoer van vervuilende stoffen. Nieuwe instrumenten moeten niet geïsoleerd worden geïntroduceerd, maar er dient te worden gezorgd voor een optimale mix, in samenhang met andere nieuwe en bestaande instrumenten. Uit nader onderzoek moet blijken of voorgestelde instrumenten passen in bestaande beleidskaders en waar geheel nieuwe instrumenten ontwikkeld moeten worden.

While many instruments have already been implemented in various chains in order to limit the emission of pollutants into water, only a fraction of the existing instruments are economic in nature, and very few are geared towards the 'polluter pays' principle (as applied in this study). Despite this, agriculture and horticulture in general, and certain sectors in particular, incur expenses in their limiting of noxious substances. There is nevertheless potential to utilize new instruments in order to give further effect to the 'polluter pays' principle. These instruments could be most effectively implemented on a company level and/or during the removal of pollutants. New instruments must not be introduced in isolation; instead, an optimum mix must be created in conjunction with other instruments, both existing and new. Further research ought to shed light on the compatibility of proposed instruments within existing policy frameworks as well as in which areas there is a need for entirely new instruments to be developed.

Trefwoorden: waterkwaliteit, watervervuiling, landbouw, emissies, financiële instrumenten

Dit rapport is gratis te downloaden op http://dx.doi.org/10.18174/378299 of op www.wageningenUR.nl/lei (onder LEI publicaties).

(C) 2016 LEI Wageningen UR

Postbus 29703, 2502 LS Den Haag, T 07033583 30, E informatie.lei@wur.nl, www.wageningenUR.nl/lei. LEI is onderdeel van Wageningen UR (University \& Research centre).

\section{(cc) BY-NC}

LEI hanteert voor haar rapporten een Creative Commons Naamsvermelding 3.0 Nederland licentie.

(C) LEI, onderdeel van Stichting Dienst Landbouwkundig Onderzoek, 2016

De gebruiker mag het werk kopiëren, verspreiden en doorgeven en afgeleide werken maken. Materiaal van derden waarvan in het werk gebruik is gemaakt en waarop intellectuele eigendomsrechten berusten, mogen niet zonder voorafgaande toestemming van derden gebruikt worden. De gebruiker dient bij het werk de door de maker of de licentiegever aangegeven naam te vermelden, maar niet zodanig dat de indruk gewekt wordt dat zij daarmee instemmen met het werk van de gebruiker of het gebruik van het werk. De gebruiker mag het werk niet voor commerciële doeleinden gebruiken.

Het LEI aanvaardt geen aansprakelijkheid voor eventuele schade voortvloeiend uit het gebruik van de resultaten van dit onderzoek of de toepassing van de adviezen.

Het LEI is ISO 9001:2008 gecertificeerd.

LEI 2016-033 | Projectcode 2282300166

Foto omslag: Shutterstock 


\section{Inhoud}

Woord vooraf $\quad 5$

$\begin{array}{ll}\text { Samenvatting } & 6\end{array}$

S.1 Belangrijkste uitkomsten $\quad 6$

S.2 Overige uitkomsten $\quad 6$

$\begin{array}{ll}\text { S.3 Methode } & 7\end{array}$

$\begin{array}{ll}\text { Summary } & 8\end{array}$

$\begin{array}{lll}\text { S.1 Key findings } & 8\end{array}$

S.2 Complementary findings $\quad 8$

$\begin{array}{ll}\text { S.3 Method } & 9\end{array}$

$\begin{array}{lr}\text { Lijst van afkortingen } & 10\end{array}$

1

Inleiding

11

1.1 Achtergrond $\quad 11$

1.2 Doel 14

$\begin{array}{lll}1.3 & \text { Afbakening } & 15\end{array}$

2

$\begin{array}{ll}\text { Aanpak } & 16\end{array}$

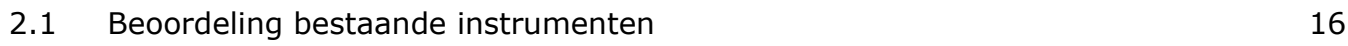

2.2 Beoordeling niet-gebruikte instrumenten 16

$\begin{array}{llr}3 & \text { Beoordeling van beleidsinstrumenten } & 18\end{array}$

$3.1 \quad$ Verschillende typen instrumenten $\quad 18$

$\begin{array}{lll}3.2 & \text { Beleidsinstrumenten } & 20\end{array}$

3.2.1 Algemene beleidsinstrumenten $\quad 20$

$\begin{array}{ll}3.2 .2 \text { Economische/financiële instrumenten } & 21\end{array}$

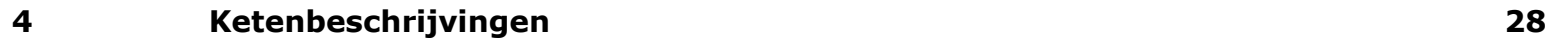

4.1 Akkerbouw en opengrondtuinbouw 29

$\begin{array}{lll}4.2 & \text { Glastuinbouw } & 31\end{array}$

$\begin{array}{lll}4.3 & \text { Intensieve veehouderij } & 33\end{array}$

$\begin{array}{lll}4.4 & \text { Melkveehouderij } & 35\end{array}$

$5 \quad$ Aan- en afvoer van stoffen $\quad 37$

$\begin{array}{lll}5.1 & \text { Nutriënten } & 37\end{array}$

5.1.1 Trends in $\mathrm{N}$ - en P-emissie 39

5.1.2 Emissies van nutriënten vanuit de glastuinbouw $\quad 40$

5.2 Gewasbeschermingsmiddelen en biociden 40

$\begin{array}{lll}5.3 & \text { Diergeneesmiddelen } & 42\end{array}$

5.4 Zware metalen $\quad 44$ 
6.1 Bestaande instrumenten per stofcategorie $\quad 45$

6.1.1 Nutriënten $\quad 45$

6.1.2 Gewasbeschermingsmiddelen en biociden 49

6.1.3 Diergeneesmiddelen 53

6.1.4 Zware metalen $\quad 55$

$\begin{array}{lll}6.2 & \text { Beoordeling bestaande instrumenten } & 57\end{array}$

$\begin{array}{llr}7 & \text { Nieuwe financiële en overige instrumenten } & 58\end{array}$

$\begin{array}{lll}7.1 & \text { Aanvoer stoffen } & 58\end{array}$

$\begin{array}{lll}7.2 & \text { Bedrijfsopzet } & 59\end{array}$

$\begin{array}{lll}7.3 & \text { Afvoer van hoofdproducten } & 60\end{array}$

$\begin{array}{lll}7.4 & \text { Afvoer van rest-/bijproducten en afval } & 61\end{array}$

8 Discussie en conclusies $\quad 63$

$\begin{array}{lll}8.1 & \text { Discussie } & 63\end{array}$

$\begin{array}{lll}8.2 & \text { Conclusies } & 66\end{array}$

$\begin{array}{ll}\text { Literatuur, websites en interviews } & 68\end{array}$

Bijlage 1 Beoordeling van mogelijke nieuwe financiële instrumenten $\quad 71$

Bijlage 2 Jaarlijkse ophoping van zware metalen in de bodem 85

$\begin{array}{lll}\text { Bijlage } 3 & \text { Regionale verdeling per sector } & 86\end{array}$

$\begin{array}{lll}\text { Bijlage } 4 & \text { Deltaplan agrarisch waterbeheer } & \mathbf{8 8}\end{array}$ 


\section{Woord vooraf}

Dit rapport is opgesteld in opdracht van het ministerie van Infrastructuur en Milieu, Directie Water en Bodem, te Den Haag. Het dient als informatie voor de beleidsvoorbereiding over de mogelijke rol van financiële instrumenten in de financiering van het waterbeheer.

LEI Wageningen UR is gevraagd om een bijdrage te leveren aan de onderbouwing voor voorstellen van een werkgroep voor eventuele aanpassingen van de financiering van het waterbeheer die begin 2017 aan de minister worden voorgelegd. Dit rapport levert een bijdrage aan de onderbouwing van deze voorstellen, waardoor de overheid meer invulling kan geven aan het 'vervuiler betaalt'-principe, door het toepassen van nieuwe economische prikkels om de emissies van nutriënten, gewasbeschermingsmiddelen en biociden, diergeneesmiddelen, en zware metalen vanuit de landbouw naar het water te beperken.

Namens de opdrachtgever is het onderzoek aangestuurd door Rob van der Veeren, Steffie Paardekooper (beiden I\&M) en Siep Groen (EZ) met de andere leden van de werkgroep Bronnen en Stoffen. Graag bedanken we de leden van deze werkgroep voor de constructieve samenwerking.

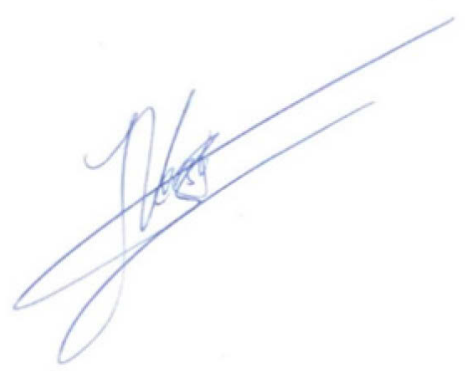

Prof. dr. ir. Jack (JGAJ) van der Vorst

Algemeen Directeur SSG Wageningen UR 


\section{Samenvatting}

\section{S.1 Belangrijkste uitkomsten}

In de diverse agrarische ketens zijn al veel instrumenten ingezet om de uitstoot van nutriënten, gewasbeschermingsmiddelen en biociden, diergeneesmiddelen, en zware metalen naar het water te beperken. Echter, slechts weinig van de bestaande instrumenten zijn economische instrumenten en weinig is gericht op het 'vervuiler betaalt'-principe, zoals gehanteerd in dit onderzoek. Wel maken de land- en tuinbouw in het algemeen, en specifieke sectoren in het bijzonder, kosten om de emissie van schadelijke stoffen te beperken.

Er zijn mogelijkheden om met nieuwe financiële instrumenten meer invulling te geven aan het 'vervuiler betaalt'-principe. Deze instrumenten kunnen het beste worden ingezet op het bedrijfsniveau en/of bij de afvoer van vervuilende stoffen. De meest voor de hand liggende instrumenten voor nadere analyse zijn instrumenten die aangrijpen op de bedrijfsopzet of de afvoer van rest/bijproducten en afval zijn: belastingen of heffingen, kortingen op heffingen en (verhogen van) boetes bij overschrijden van grenzen. Zie het overzicht in Tabel S.1.

\section{Tabel S.1}

Overzicht welke financiële instrumenten waar in de keten mogelijk een bijdrage kunnen leveren

\begin{tabular}{|c|c|c|c|c|}
\hline Instrument & Aanvoer & Bedrijfsopzet & $\begin{array}{c}\text { Afvoer } \\
\text { hoofdproduct }\end{array}$ & $\begin{array}{c}\text { Afvoer } \\
\text { bijproduct/afval }\end{array}$ \\
\hline \multicolumn{5}{|l|}{ Prijspremie } \\
\hline \multicolumn{5}{|l|}{ Subsidies } \\
\hline $\begin{array}{l}\text { Belasting of heffing en } \\
\text { Kortingen op heffingen }\end{array}$ & $\sqrt{ }$ & $\sqrt{ }$ & & $\checkmark$ \\
\hline $\begin{array}{l}\text { (Verhogen van) boetes bij } \\
\text { overschrijden van } \\
\text { grenzen }\end{array}$ & & $\sqrt{ }$ & & $\checkmark$ \\
\hline \multicolumn{5}{|l|}{$\begin{array}{l}\text { Braak/leegstand } \\
\text { programma's }\end{array}$} \\
\hline (verhandelbare) Quota & & $?$ & & $?$ \\
\hline
\end{tabular}

Aanbevolen wordt om te zoeken naar synergie door met nieuwe instrumenten aan te sluiten bij andere ontwikkelingen in beleid en markt. Nieuwe instrumenten moeten niet geïsoleerd worden geïntroduceerd, maar er dient te worden gezorgd voor een optimale mix, in samenhang met andere nieuwe en bestaande instrumenten. Uit nader onderzoek moet blijken of voorgestelde instrumenten passen in bestaande beleidskaders en waar geheel nieuwe instrumenten ontwikkeld moeten worden.

\section{S.2 Overige uitkomsten}

Uit de analyse van het bestaande instrumentarium blijkt dat regelgeving zeer effectief is geweest voor het terugdringen van emissies, bijvoorbeeld voor regulering grondontsmetting, activiteitenbesluit milieubeheer en stikstof-/fosfaatnormen. De regelgeving werd voorafgegaan door kennisontwikkeling en kennisverspreiding, waardoor de bedrijfsvoering kon worden aangepast zonder dat het hoge kosten of andere problemen opleverde.

Belangrijk nadeel bij een aantal mogelijke instrumenten, gericht op 'de vervuiler betaalt', is dat er een uitgebreid controleapparaat nodig is. Dit vereist ook de bereidheid en capaciteit om te handhaven, 
met proportionele maatregelen, zodat het instrument voldoende effectief is en ook het draagvlak bij bedrijven behouden blijft.

Het blijkt dat mensen het effect van winst en verlies niet als gelijk inschatten. Ondernemers zullen naar verwachting meer moeite doen om een mogelijke heffing te voorkomen dan dat ze moeite zullen doen om een bonus of premie van dezelfde omvang te verwerven. Door hier slim gebruik van te maken kan door het zorgvuldig 'framen' van mogelijke financiële beleidsinstrumenten het effect van beleidsinterventies vergroot worden.

De beschreven beleidsinstrumenten komen het beste tot hun recht als er volgtijdelijkheid en samenspel is tussen instrumenten en belanghebbenden. Aansluiten bij lopende initiatieven en onderling afstemmen van extra instrumenten kunnen een bijdrage leveren aan het 'vervuiler betaalt'principe en het ingezette beleid versterken. Een slimme combinatie van subsidies, heffingen en boetes kan bijdragen aan zowel de financierbaarheid van het maatregelenpakket als ook aan de kostenterugwinning van het waterbeheer.

\section{S.3 Methode}

Om inzicht te geven in de mogelijkheden van financiële instrumenten om meer invulling te geven aan het 'vervuiler betaalt'-principe, zoals gehanteerd in dit onderzoek, is eerst een inventarisatie gemaakt van instrumenten. Doel is het beperken van emissies van nutriënten, gewasbeschermingsmiddelen en biociden, diergeneesmiddelen en zware metalen naar het water. Per stofcategorie is inzicht gegeven in de gebleken of verwachte effectiviteit van de beschreven instrumenten. Bestaande instrumenten zijn geduid aan de hand van het RESET-model. Dit model gaat uit van een combinatie van

- regels

- educatie

- sociale druk

- economische incentives

- tools.

Deze vijf elementen zijn nodig om ondernemers te stimuleren tot gedragsverandering.

Vervolgens is voornamelijk gekeken naar de mogelijke rol van nog niet gebruikte instrumenten, met de nadruk op financiële instrumenten, om in het waterbeheer meer invulling te geven aan het 'vervuiler betaalt'-principe en gedragsbeïnvloeding in de keten. Hierbij is breed gekeken naar maatregelen die de finale emissie van schadelijke stoffen verminderen: minder aanvoer op het bedrijf, maatregelen op het bedrijf die de noodzaak van gebruik verminderen of financiële prikkels rond het lozen van (afval)stoffen. Bij de beoordeling van diverse instrumenten zijn de volgende criteria gebruikt:

- doeltreffendheid

- impact op overheidskosten

- controleerbaarheid/handhaafbaarheid

- draagvlak bij ondernemers

- toekomstbestendigheid. 


\section{Summary}

\section{S.1 Key findings}

While many instruments have already been implemented in various chains in order to limit the emission of nutrients, crop protection agents and biocides, veterinary medicines and heavy metals into water, only a fraction of the existing instruments are economic in nature, and very few are geared towards the 'polluter pays' principle, as applied in this study. Despite this, agriculture and horticulture in general, and certain sectors in particular, incur expenses in their limiting of noxious substances.

There is nevertheless potential to utilise new financial instruments in order to give further effect to the 'polluter pays' principle. These instruments could be most effectively implemented on a company level and/or during the removal of pollutants. The most obvious instruments for further analysis are those that affect business systems or the removal of residual products, by-products and waste are: taxes or levies; tax credits; and penalties or more severe penalties when limits are exceeded. See the overview in Table S.1.

\section{Table S. 1}

Overview of which financial instruments in the chain can offer a contribution

\begin{tabular}{|c|c|c|c|c|}
\hline Instrument & Supply & Business structure & $\begin{array}{c}\text { Removal of main } \\
\text { product }\end{array}$ & $\begin{array}{l}\text { Removal of by- } \\
\text { product/waste }\end{array}$ \\
\hline \multicolumn{5}{|l|}{ Price premium } \\
\hline \multicolumn{5}{|l|}{ Subsidies } \\
\hline $\begin{array}{l}\text { Tax or levy and tax } \\
\text { credits }\end{array}$ & $\sqrt{ }$ & $\sqrt{ }$ & & $\sqrt{ }$ \\
\hline $\begin{array}{l}\text { Penalties and more } \\
\text { severe penalties when } \\
\text { limits are exceeded }\end{array}$ & & $\sqrt{ }$ & & $\sqrt{ }$ \\
\hline \multicolumn{5}{|l|}{$\begin{array}{l}\text { Programmes for fallow } \\
\text { and vacant land }\end{array}$} \\
\hline (Tradable) Quotas & & $?$ & & $?$ \\
\hline
\end{tabular}

Effort should be invested in creating synergies by establishing a link between new instruments and other developments in terms of policy and the market. New instruments must not be introduced in isolation; instead, an optimum mix must be created in conjunction with other instruments, both existing and new. Further research ought to shed light on the compatibility of proposed instruments within existing policy frameworks as well as in which areas there is a need for entirely new instruments to be developed.

\section{S.2 Complementary findings}

The analysis of the existing set of instruments demonstrates that legislation and regulations have been very effective in reducing emissions. Legislation and regulations include the Regulering Grondontsmetting (the Dutch regulations on soil decontamination, RGO), the Dutch Activities Decree (Activiteitenbes/uit milieubeheer) and nitrate/phosphate standards. The legislation and regulations were preceded by expertise development and expertise dissemination, which allowed for modifications to be performed in operational management without incurring large expenses or causing other problems. 
A significant disadvantage of a number of possible instruments that are geared towards the 'polluter pays' principle is that they necessitate extensive control apparatus. In addition, this entails the readiness and ability to implement these controls alongside proportional measures, so that the instrument is sufficiently effective and the support at companies is maintained.

It appears that people do not judge the effects of profit and loss as equal. It is expected that entrepreneurs will invest more effort in avoiding a possible levy than in obtaining a bonus or premium of an equal scope. The effect of policy interventions can be augmented by making intelligent use of this knowledge by carefully laying out the parameters of potential financial policy instruments.

The policy instruments described are at their most effective when there is continuity and interaction between the instruments and the interested parties. By linking these to ongoing initiatives and harmonising additional instruments to one other, it is possible to make a contribution to the 'polluter pays' principle and strengthen implemented policy. A smart combination of grants, levies and penalties can improve both the fundability of the set of measures as well as the cost recovery in water management.

\section{S.3 Method}

Stock must first be taken of instruments in order to provide an insight into the possibility of financial instruments to give further effect to the 'polluter pays' principle as applied in this study. The aim is to limit the emissions of nutrients, crop protection agents and biocides, veterinary medicines and heavy metals into water. Information has been provided per substance category in the proven or expected effectiveness of the instruments described. Existing instruments are indicated using the RESET model. This model is based on a combination of:

- rules

- education

- social pressure

- economic incentives

- tools.

These five elements are necessary if entrepreneurs are to be encouraged to change their behaviour.

Subsequently, particular attention was paid to the possible role of as yet unused instruments - with emphasis on financial instruments - in order to give further effect to the 'polluter pays' principle as well as behaviour change in the chain in terms of water management. A broad spectrum of measures that reduce the final emission of noxious substances was taken into account. These measures include: less supply to the company, measures at the company that reduce the need for use and financial incentives with regards to the discharging of substances and waste substances. The following criteria were used in assessing various instruments:

- effectiveness

- impact on public costs

- controllability/enforceability

- support for entrepreneurs

- future viability. 


\section{Lijst van afkortingen}

$\begin{array}{ll}\text { BAW } & \text { Bestuursakkoord Water } \\ \text { CTGB } & \text { College voor de toelating van gewasbeschermingsmiddelen en biociden } \\ \text { EC } & \text { De Europese Commissie } \\ \text { FIDIN } & \text { De branchevereniging van veterinaire farmacie in Nederland } \\ \text { GLB } & \text { Gemeenschappelijk Landbouwbeleid } \\ \text { JG-MKN } & \text { de Jaargemiddelde- milieukwaliteitsnormen } \\ \text { MAC-MKN } & \text { de Maximaal Aanvaardbare Concentratie milieukwaliteitsnormen } \\ \text { KRW } & \text { Kaderrichtlijn Water } \\ \text { OECD } & \text { The Organisation for Economic Co-operation and Development } \\ \text { PAS } & \text { Programmatische Aanpak Stikstof } \\ \text { RESET } & \text { Regels, Educatie, Sociale druk, Economische incentives en Tools } \\ \text { SDa } & \text { Stichting Diergeneesmiddelen Autoriteit } \\ \text { TOPPS } & \text { Train Operators to Promote best Practices and Sustainability }\end{array}$




\section{$1 \quad$ Inleiding}

Watermanagement confronteert Nederland met een aantal uitdagingen: hoe kunnen met elkaar gerelateerde risico's van te veel en te weinig water, watervervuiling en risico's rond de weerbaarheid van zoetwaterecosystemen het beste worden aangepakt? Hierbij hoort ook een discussie over de financiering van ons waterbeheer op de lange termijn; dit mede als reactie op het OECD-rapport ${ }^{1}$ en de daarin gestelde uitdagingen. De minister van Infrastructuur en Milieu heeft aangegeven deze discussie te willen voeren. Naast inventarisatie van huidige bekostiging in het Nederlandse waterbeheer en van relevante toekomstige ontwikkelingen is er een discussie of het mogelijk is om het principe van 'de gebruiker/ vervuiler/veroorzaker/ belanghebbende betaalt' (kortweg: het 'vervuiler betaalt'-principe) nog beter toe te passen in de financiering van het waterbeheer. Dit zou moeten leiden tot gedragen voorstellen voor eventuele aanpassingen van de financiering van het waterbeheer die begin 2017 aan de minister worden aangeboden.

Dit rapport levert een bijdrage aan de onderbouwing van deze voorstellen, waardoor de overheid meer invulling kan geven aan het 'vervuiler betaalt'-principe door het toepassen van nieuwe economische prikkels om de emissies van nutriënten, gewasbeschermingsmiddelen en biociden, diergeneesmiddelen, en zware metalen vanuit de landbouw naar het water te beperken.

Op basis van de inventarisatie en analyse kan door de opdrachtgever een advies worden gegeven over de richting waarin de werkgroep Bronnen en Stoffen met daarin partners van het Bestuursakkoord Water (BAW) partners in 2016 verder zou moeten kijken: welke knoppen/maatregelen en economische instrumenten om emissies vanuit de landbouw naar het water te reduceren zijn het meest kansrijk?

\section{$1.1 \quad$ Achtergrond}

Het 'vervuiler betaalt'-principe

Het 'vervuiler betaalt'-principe is een belangrijke onderdeel van het milieubeleid geworden, zowel nationaal als internationaal, na de adoptie door de OECD in 1972 als een van de leidende principes in relatie tot internationale aspecten van milieubeleid. Dit principe wordt gewoonlijk geïnterpreteerd als zowel (1) een principe van kostenallocatie als (2) een principe van kosteninternalisatie. Met betrekking tot kostenallocatie gaat het om de vraag: wie betaalt voor de preventie en controle van vervuiling? De kosteninternalisatie is gericht op het vergroten van de economische efficiëntie door het internaliseren van externe milieukosten van productie en consumptie in marktprijzen. Er is geen eenduidig beeld welke kosten geïnternaliseerd moeten worden. Wel is er overeenstemming dat het principe minimaal omvat de kosten van preventie en controle van vervuiling die gerelateerd zijn aan milieumaatregelen van de publieke autoriteiten zodat het milieu in een acceptabele staat is. Echter, overheden kunnen besluiten welke en in hoeverre deze kosten geïnternaliseerd worden (Tobey en Smets, 1996).

Door middel van bijvoorbeeld heffingen, belastingen of waterschapomslagen dragen landbouwbedrijven bij aan de kosten die gemaakt worden om water te zuiveren. Dit is te zien als een vorm van internalisatie van milieukosten. Vaak zijn deze heffingen generiek en wordt er weinig onderscheid gemaakt tussen bedrijven die veel of weinig bijdragen aan de emissies van vervuilende stoffen vanuit de landbouw.

\footnotetext{
${ }^{1}$ www.rijksoverheid.nl/binaries/rijksoverheid/documenten/rapporten/2014/03/17/oecd-studies-on-water-watergovernance-in-the-netherlands-fit-for-the-future/oecd-studies-on-water-water-governance-in-the-netherlands-fit-for-thefuture.pdf
} 
Er zijn twee niveaus van kosten te onderscheiden: sectorbrede kosten en kosten voor het individuele bedrijf. Sectorbrede kosten zijn kosten die moeten worden gemaakt door het bedrijfsleven om te voldoen aan de huidige wet- en regelgeving. Maatregelen die een hele sector/de hele landbouw neemt om generiek de emissie naar beneden te brengen gaan gepaard met substantiële kosten (De Koeijer et al., 2015). Zo bedragen de jaarkosten voor de landbouw door het mestbeleid in $2013 € 101 \mathrm{mln}$. In 2015 is dit naar verwachting $€ 159 \mathrm{mln}$. $^{2}$ De jaarkosten van het gewasbeschermingsmiddelenbeleid voor 2013 bedragen in totaal $€ 78 \mathrm{mln}$. Hiervan is $€ 18 \mathrm{mln}$. voor de akkerbouw en $€ 60 \mathrm{mln}$. voor de glastuinbouw. Ook de kosten ten gevolge van het gewasbeschermingsbeleid zullen toenemen. De omvang hiervan kan niet worden aangegeven. Dit is afhankelijk van de maatregelen die in het Activiteitenbesluit Milieubeheer worden vastgelegd (De Koeijer et al., 2015).

Instrumenten kunnen ook gericht zijn op het individuele bedrijf binnen een sector. Daarmee wordt onderscheid gemaakt tussen bedrijven die meer of minder schadelijke stoffen emitteren naar het grond- en oppervlaktewater en er kunnen specifieke instrumenten zijn die de veel emitterende bedrijven meer laten bijdragen aan de kosten van het waterbeheer (betalen naar gebruik of naar vervuiling). In deze studie ligt de nadruk op het individuele bedrijf en op de instrumenten die binnen een sector de emissie van schadelijke stoffen kunnen terugdringen. Er wordt vooral gekeken of instrumenten bijdragen aan het specifiek belasten van bedrijven naar rato van emissies. De vervuiler krijgt met een extra economische prikkel te maken.

\section{Doel- of middelvoorschriften}

Middelvoorschriften zijn voorschriften die voorschrijven wat je moet doen en doelvoorschriften zijn voorschriften die voorschrijven wat je moet bereiken. Een middelvoorschrift is relatief simpel en goed handhaafbaar. Een doelvoorschrift daarentegen is lastiger, want er komt een beoordeling bij kijken: zijn de genomen maatregelen wel effectief om het gestelde doel te bereiken? Het veronderstelt deskundigheid bij de beoordelaar. Doelvoorschriften veelal efficiënter dan middelvoorschriften, omdat je innovatie toelaat. Een belangrijk voordeel van doelvoorschriften is dat het niet uitmaakt waar in de keten maatregelen genomen worden die resulteren in de laagste emissie van schadelijke stoffen op het primaire bedrijf. In deze studie wordt dan ook het primaire agrarische bedrijf beschreven met daarbij aandacht voor de aanvoer en afvoer van stoffen op het bedrijf.

\section{Beoordeling oppervlaktewater voor verontreinigende stoffen}

De Europese Kaderrichtlijn Water (KRW) richt zich op de bescherming van water en stelt zich ten doel dat alle Europese wateren in het jaar 2015 een 'goede toestand' hebben bereikt en dat er in heel Europa duurzaam wordt omgegaan met water. De bescherming van alle wateren heeft zowel betrekking op rivieren, meren, kustwateren als op grondwateren.

Binnen de KRW is een methode vastgesteld voor de beoordeling van de kwaliteit van het oppervlaktewater gebaseerd op biologie en toxische stoffen. De kwaliteit van het oppervlaktewater wordt uitgedrukt in de chemische kwaliteit en de ecologische kwaliteit, ook chemische en ecologische toestand genoemd. De voor dit onderzoek relevante stoffen worden genoemd onder de 'overig relevante verontreinigende stoffen'. Dit kwaliteitselement wordt bepaald door een honderdtal stoffen. Per stroomgebied is vastgesteld welke stoffen worden beoordeeld. ${ }^{3}$

Uit de ex-ante evaluatie van het Planbureau voor de Leefomgeving (PBL) blijkt dat de waterkwaliteit en de inrichting van de watersystemen wel verbeteren, maar dat deze in veel wateren nog onvoldoende zijn om de ecologische doelen te halen (PBL, 2016). Van sommige stoffen van de Europese lijst van probleemstoffen wordt nog regelmatig de norm overschreden. Dit zijn vooral stoffen die inmiddels niet meer worden geloosd, maar zich nog steeds in de wateren bevinden.

\footnotetext{
2 De kosten voor de veehouderijsectoren bedragen $€ 386 \mathrm{mln}$. Dit zijn de mestafzetkosten van de intensieve veehouderij. De baten voor de akkerbouw, extensieve veehouderij en opengrondstuinbouw bedragen $€ 227 \mathrm{mln}$. Dit is voornamelijk de vergoeding voor plaatsingsruimte mest en besparing kunstmestkosten voor de akkerbouw, de extensieve veehouderij en de opengrondtuinbouw die mest aanvoeren.

3 www.compendiumvoordeleefomgeving.nl/indicatoren/nl1412-Kaderrichtlijn-water.html?i=26-208
} 
Er zijn grote verschillen in de waterkwaliteit, tussen de grote rivieren, kleinere rivieren, kanalen, meren, en op lokaal niveau (waterlopen, sloten).

De regie voor de uitvoering van de Europese Kaderrichtlijn Water voor de stroomgebiedbeheerplannen ligt voor de regionale wateren vooral bij de waterschappen, met de volgende maatregelen:

- puntbronnen verminderen belasting rioolwaterzuiveringsinstallaties (44 gerealiseerd in 2014, 58 gepland)

- diffuse bronnen aanleggen van mest- en spuitvrije zones (820 km gerealiseerd, $810 \mathrm{~km}$ gepland)

- hydromorfologie aanleggen van natuurvriendelijke oevers/hermeanderen (2.450 km gerealiseerd, $2.500 \mathrm{~km}$ gepland)

- inrichting vispassages (620 km gerealiseerd, $580 \mathrm{~km}$ gepland).

Kosten waterbeheer in Nederland

In Tabel 1.1 is weergegeven wat de kosten zijn van het Nederlandse waterbeheer.

\section{Tabel 1.1}

Overzicht kosten in miljoenen euro's en terugverdienpercentage ${ }^{1}$ waterdiensten in Nederland in 2013

\begin{tabular}{|c|c|c|c|c|c|}
\hline Waterdienst & $\begin{array}{l}\text { Aanbieder } \\
\text { waterdienst }\end{array}$ & $\begin{array}{l}\text { Gebruiker } \\
\text { waterdienst }\end{array}$ & $\begin{array}{l}\text { Totale kosten } \\
\text { (in mln. euro's) }\end{array}$ & $\begin{array}{l}\text { Terugverdien- } \\
\text { percentage a) }\end{array}$ & $\begin{array}{c}\text { Terugverdien- } \\
\text { middel }\end{array}$ \\
\hline $\begin{array}{l}\text { Productie en } \\
\text { levering van } \\
\text { water }\end{array}$ & $\begin{array}{l}\text { Drinkwater- } \\
\text { bedrijven } \\
\text { Bedrijven } \\
\text { Landbouw }\end{array}$ & $\begin{array}{l}\text { Huishoudens } \\
\text { Bedrijven }\end{array}$ & $\begin{array}{r}1.384 \\
198 \text { (koelwater) } \\
194 \text { (proceswater) } \\
0,4 \\
\text { (landb.aansluitingen } \\
\text { in 2000) b) } \\
45 \text { (beregening) }\end{array}$ & 100 & $\begin{array}{c}\text { Vastrecht, } \\
\text { euro's/m }{ }^{3}, \\
\text { eigen } \\
\text { kosten/beheer }\end{array}$ \\
\hline $\begin{array}{l}\text { Inzameling en } \\
\text { afvoer van } \\
\text { hemelwater en } \\
\text { afvalwater }\end{array}$ & Gemeenten & $\begin{array}{l}\text { Huishoudens } \\
\text { Bedrijven } \\
\text { Landbouw }\end{array}$ & $\begin{array}{r}1.462 \\
0,3\end{array}$ & 105 & Rioolrecht \\
\hline $\begin{array}{l}\text { Zuivering van } \\
\text { afvalwater }\end{array}$ & $\begin{array}{l}\text { Waterschappen } \\
\text { Bedrijven } \\
\text { Landbouw }\end{array}$ & $\begin{array}{l}\text { Huishoudens } \\
\text { Bedrijven } \\
\text { Landbouw }\end{array}$ & $\begin{array}{r}1.001 \\
353 \\
6 \text { (in 2000) }\end{array}$ & 100 & $\begin{array}{l}\text { Verontrei- } \\
\text { nigings- } \\
\text { heffing, } \\
\text { eigen } \\
\text { kosten/beheer }\end{array}$ \\
\hline $\begin{array}{l}\text { Grondwater- } \\
\text { beheer }\end{array}$ & Provincies & $\begin{array}{l}\text { Bedrijven } \\
\text { Landbouw } \\
\text { Natuur }\end{array}$ & $18 \mathrm{~b})$ & 100 & $\begin{array}{l}\text { Grondwater- } \\
\text { heffing, } \\
\text { grondwater- } \\
\text { belasting }\end{array}$ \\
\hline $\begin{array}{l}\text { Regionaal } \\
\text { watersysteem } \\
\text { beheer }\end{array}$ & Waterschappen & $\begin{array}{l}\text { Huishoudens } \\
\text { Bedrijven } \\
\text { Landbouw }\end{array}$ & $\begin{array}{r}1.105333 \\
47 \text { (drainage } \\
+ \text { waterberging) b) }\end{array}$ & 96 & $\begin{array}{l}\text { Water- } \\
\text { schaps- } \\
\text { omslagen }\end{array}$ \\
\hline Vaarwegenbeheer & $\begin{array}{l}\text { Rijk } \\
\text { Provincies } \\
\text { Waterschappen } \\
\text { Gemeenten }\end{array}$ & $\begin{array}{l}\text { Scheepvaart } \\
\text { Recreatie } \\
\text { Handel }\end{array}$ & 1.316 & & $\begin{array}{c}\text { Algemene } \\
\text { middelen+ } \\
\text { sectorbijdragen }\end{array}$ \\
\hline Waterveiligheid & $\begin{array}{l}\text { Rijk } \\
\text { Provincies } \\
\text { Waterschappen }\end{array}$ & Alle sectoren & 1.169 & & $\begin{array}{l}\text { Algemene } \\
\text { middelen }\end{array}$ \\
\hline
\end{tabular}

a) Terugverdienpercentage: de mate waarin gemaakte kosten voor waterdiensten door regionale overheden en waterschappen door heffingen en belastingen bij de diverse gebruikers worden terugverdiend; b) Sterk Consulting en Bureau Buiten, Rapport Kostenterugwinning van Waterdiensten in 2013, LEI bewerking

Bron: Twijnstra Gudde \& Tauw; Toekomstbestendige en duurzame financiering van het Nederlandse waterbeheer, juni 2015, LEI bewerking 
Het waterbeheer in Nederland is een kostbare gelegenheid, waarbij veel verschillende publieke en private partijen betrokken zijn. Tabel 1.1 laat zien welke grote financiële geldstromen nodig zijn voor de kwaliteit en kwantiteit van het waterbeheer. Het merendeel $(72 \%)$ van deze kosten worden door de gebruikers van al deze diensten direct terugbetaald, via allerlei specifieke heffingen. De kosten voor waterveiligheid en de grotere vaarwegen worden doorgaans voor het grootste deel uit de algemene middelen betaald.

De kosten voor de afvalwaterketen bedroegen ruim $€ 3$ miljard en voor drinkwater bijna $€ 1,4$ miljard (Figuur 1.1). De kosten worden in ongeveer gelijke mate gemaakt door de waterschappen, gemeenten en drinkwaterbedrijven. In de huidige financiering zijn weinig expliciet gedragsbeïnvloedende financiële prikkels aanwezig; slechts bij een aantal watertaken en -diensten wordt jaarlijks echt afgerekend op de mate van gebruik (bijvoorbeeld de drinkwaterrekening) of kostenveroorzaking (bijvoorbeeld de zuiveringsheffing voor bedrijven) (Twijnstra-Gudde en Tauw, 2015).

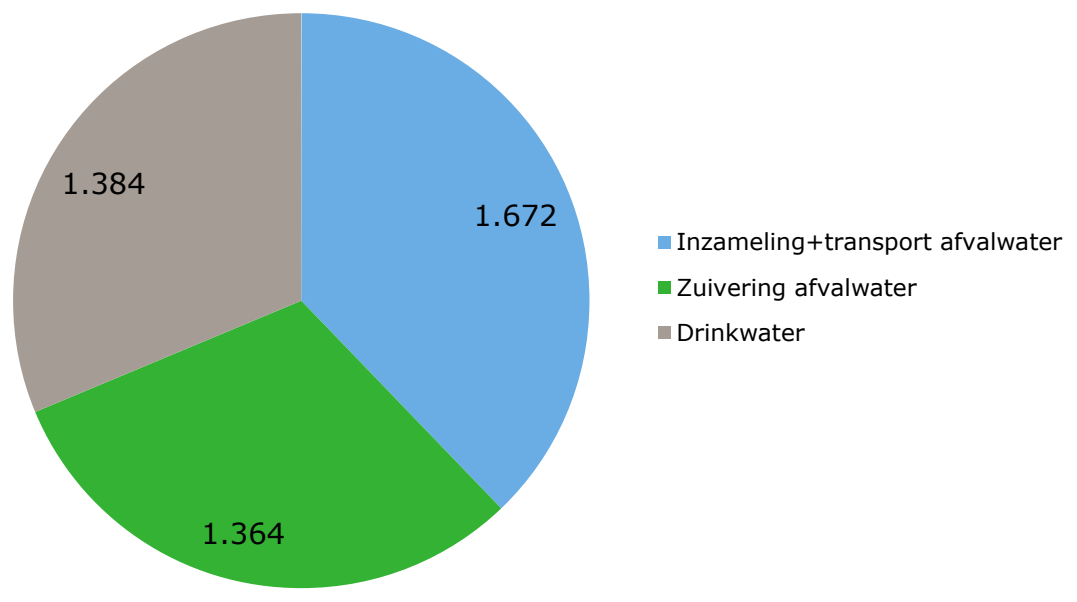

Figuur 1.1 Kosten afvalwaterketen en drinkwater in miljoen $€$ Bron: Twijnstra-Gudde en Tauw (2015), bewerking LEI

\subsection{Doel}

Doel van het onderzoek is het identificeren van (met name nieuwe en aanvullende) financiële instrumenten in het waterbeheer, waarmee meer invulling wordt gegeven aan het 'vervuiler betaalt'principe en sturing van het gedrag van individuele bedrijven. Het gaat daarbij om instrumenten die gewenst gedrag belonen en vervuilend gedrag belasten. Instrumenten die kunnen worden ingezet in de hele keten vanaf middelenfabrikant tot en met emissie naar oppervlaktewater/grondwater, met als doel het reduceren van emissies van nutriënten, gewasbeschermingsmiddelen en biociden, diergeneesmiddelen, en zware metalen op primaire landbouwbedrijven naar het water.

Naast aandacht voor financiële instrumenten, zoals bijvoorbeeld een subsidie of een heffing, zal op hoofdlijnen aandacht worden besteed aan mogelijke andere instrumenten, zoals bijvoorbeeld wet- en regelgeving, educatie en communicatie, sociale druk, en tools. Hiervoor wordt het RESET-model gebruikt dat ervan uitgaat dat een combinatie van Regels, Educatie, Sociale druk, Economische incentives en Tools nodig is om ondernemers tot gedragsverandering aan te zetten. ${ }^{4}$ Het RESET-model wordt ook gebruikt om van het bestaand instrumentarium vast te stellen op welke onderdelen van de RESET-combinatie het instrumentarium gericht is.

\footnotetext{
4 Conference Paper: How to R.E.S.E.T farmer mindset? Experiences from The Netherlands, Jolanda Jansen, Roeland Wessels, T.J.G.M. Lam. Countdown Symposium, Melbourne, Australia, Countdown Symposium, Melbourne, Australia; 07/2012.
} 


\subsection{Afbakening}

- In dit onderzoek is gebruik gemaakt van bestaande data en literatuur, aangevuld met enkele expertinterviews (zie referenties). Er is geen nieuw onderzoek uitgevoerd. De diverse instrumenten zijn alleen kwalitatief en op hoofdlijnen beoordeeld.

- De ketens zijn eenvoudig, op hoofdlijnen beschreven vanuit het perspectief van inputs en mogelijke emissies naar milieu en oppervlaktewater. Er wordt geen uitputtend overzicht gegeven van alle genomen maatregelen in de verschillende ketens.

- De meeste maatregelen zijn vrij generiek en abstract beschreven. Ter verduidelijking zijn op basis van literatuursuggesties van de opdrachtgever enkele illustratieve voorbeelden wat uitgebreider beschreven.

- Biociden worden samen met de gewasbeschermingsmiddelen behandeld. Indien er specifieke zaken zijn rond biociden wordt dit separaat gemeld.

- De beschrijving van de ketens beperkt zich tot landelijk niveau en tot die land- en tuinbouwsectoren waar de grootste aanvoer en emissies van schadelijke stoffen plaatsvinden.

- De focus van het onderzoek is het primaire bedrijf als diffuse bron. Instrumenten in de keten worden beschreven vanuit het perspectief van het primaire bedrijf: hoe dragen deze instrumenten bij aan sturing op het minder gebruik van stoffen op het primaire bedrijf?

- Dit onderzoek gaat niet uitgebreid in op mogelijke technische ontwikkelingen op het gebied van waterbeheer of emissiebeperkende maatregelen. Als concrete ontwikkelingen genoemd worden is dit alleen ter illustratie en niet met de bedoeling uitputtend te zijn.

- Ten aanzien van diffuse verontreiniging vanuit de landbouw is als primair doel geformuleerd dat economische instrumenten vooral gericht moeten zijn op het geven van aanvullende prikkels en versterking van het 'vervuiler betaalt'-principe, en niet op kostenterugwinning. Om die reden is in deze studie geen aandacht besteed aan de mogelijkheden voor kostenterugwinning. Financiële maatregelen die bijdragen aan vervuiler-betaalt kunnen ook bijdragen aan kostenterugwinning maar de nadruk ligt op het 'vervuiler betaalt'-principe. 


\section{$2 \quad$ Aanpak}

Dit onderzoek probeert inzicht te geven in financiële instrumenten die ingezet kunnen worden in de keten waardoor op het primaire land- en tuinbouwbedrijf de aanvoer en emissies van schadelijke stoffen beperkt kan worden. Op basis van de literatuur en expertkennis wordt per stofcategorie inzicht gegeven in de gebleken of verwachte effectiviteit van de beschreven instrumenten. Om inzicht te krijgen in de gestelde onderzoeksvragen zijn de hierna genoemde activiteiten uitgevoerd.

\subsection{Beoordeling bestaande instrumenten}

De bestaande instrumenten zullen worden geduid aan de hand van het RESET-model. Dit model gaat ervan uit dat een combinatie van Regels, Educatie, Sociale Druk, Economische Incentives en Tools nodig is om ondernemers te stimuleren tot gedragsverandering. In paragraaf 3.1 wordt hier dieper op ingegaan.

Naast een generieke beschrijving van de instrumenten zijn ook enkele illustratieve voorbeelden beschreven.

\subsection{Beoordeling niet-gebruikte instrumenten}

Het doel is inzicht in de mogelijke rol van (nieuwe en aanvullende) instrumenten, met name financiële instrumenten, om in het waterbeheer meer invulling te geven aan het 'vervuiler betaalt'-principe en gedragsbeïnvloeding in de keten. Hierbij is breed gekeken naar maatregelen die de finale emissie van schadelijke stoffen verminderen: minder aanvoer op het bedrijf, maatregelen op het bedrijf die de noodzaak van gebruik verminderen of financiële prikkels rond het lozen van (afval)stoffen.

Het (potentiële) effect van afzonderlijke maatregelen is kwalitatief beoordeeld op basis van literatuur en expertkennis. Voor de beschrijving van de mogelijke toepasbaarheid van financiële en andere instrumenten in de keten is deze opgesplitst in de volgende vier onderdelen:

- aanvoer stoffen

- bedrijfsopzet

- afvoer van hoofdproducten

- afvoer van rest-/bijproducten en afval (inclusief de emissies/lozingen van milieubelastende stoffen die het watermilieu belasten).

Daarbij zijn de volgende beoordelingscriteria gebruikt:

- doeltreffendheid (= effectiviteit; mate van bijdrage aan het beoogde doel; belangrijk aspect hierbij is de prijselasticiteit; doel is sturing van het gebruik, principe 'vervuiler betaalt')

- impact op overheidskosten (= doelmatigheid/efficiëntie; hoogte van de maatschappelijke kosten voor het inzetten van het instrument, relatief, in verhouding tot de effectiviteit)

- Een belangrijk onderdeel hiervan zijn de administratieve lasten voor de overheid, inclusief de 'perceptiekosten' (= kosten van heffing en inning; met name kleinere heffingen bij een groot aantal gebruikers leidt tot hoge systeemkosten; dit kan worden ondervangen door het gebruik van drempelwaarden)

- Buiten beschouwing blijft de betaalbaarheid op lange termijn (kostenterugwinning), omdat de prikkels in de landbouw gericht zijn op sturing van het gebruik, niet op kostenterugwinning. Echter financiële maatregelen die bijdragen aan vervuiler-betaalt kunnen ook bijdragen aan kostenterugwinning, maar dit is geen beoordelingscriterium. 
- controleerbaarheid/handhaafbaarheid

- Onderdeel hiervan is de technische/praktische uitvoerbaarheid voor de overheid en waterbeheerders

- draagvlak bij ondernemers Hoe staat ondernemer tegenover het instrument (houding/attitude), zowel wat betreft doel/ achtergrond van het instrument als wat betreft praktische uitvoerbaarheid?

- Transparantie: is de inzet van het instrument goed uit te leggen aan de betrokkenen?

- Impact van extra kosten voor ondernemers

- Praktische uitvoerbaarheid voor ondernemers

- Mening van voor de ondernemer belangrijke actoren in de omgeving en de invloed van hun mening op die van de ondernemers.

- Toekomstbestendigheid

- Draagt het instrument vooral bij aan korte termijn doelen of helpt het ook lange termijn doelen te realiseren?

- Staat de inzet van het instrument toekomstige innovaties niet in de weg? (bv. omdat het alleen op korte termijn doelen is gericht is)

- Hoe flexibel is het instrument zelf? Kan er ingespeeld worden op veranderingen? 


\section{Beoordeling van beleidsinstrumenten}

\subsection{Verschillende typen instrumenten}

\section{Doel- of maatregelgericht}

Het formuleren van alternatieve beleidsinstrumenten begint met de vraag of de huidige instrumenten in lijn zijn met de gewenste ontwikkeling. Indien de resultaten rond deze ontwikkelingen niet voldoende zijn, is beleidsaanpassing wellicht noodzakelijk. Actoren zullen hun gedrag moeten aanpassen. Bij aanpassing van de strategie kan gekozen worden voor een strategie die doelgericht (het uiteindelijke doel moet worden bereikt, het staat de actor vrij om te kiezen voor welke set van specifieke maatregelen gekozen wordt) of maatregelgericht (een specifieke maatregel moet worden geïmplementeerd waarbij de verwachting is dat dit resulteert in het gewenste doel) is.

De keuze van het beleidsinstrument wordt mede bepaald door de sense of urgency bij beleidsmakers, de beschikbaarheid van effectieve maatregelen en de afrekenbaarheid van individuele actoren. De effectiviteit van de beleidsmaatregel is grotendeels afhankelijk van de doelgroepen en de socioeconomische context. Is de doelgroep bereid actie te ondernemen? Is er voldoende druk vanuit de omgeving en is de doelgroep in staat om adequate actie te ondernemen? Zijn de voorgestelde maatregelen kosteneffectief op bedrijfsniveau, praktisch implementeerbaar, voldoende relevant op sectorniveau met voldoende impact zonder nadelige neveneffecten? Als aan deze voorwaarden voldaan is staat niets de succesvolle introductie van een beleidsmaatregel meer in de weg.

\section{Modellen over gedragsbeïnvloeding}

Om het gedrag van ondernemers te beïnvloeden, kunnen verschillende soorten instrumenten worden ingezet. Het hangt van de ondernemer af welk type instrument, of welke combinatie van instrumenten het beste bij hem of haar past. In de literatuur zijn er vele beschreven.

Jansen et al. (2012) hebben het RESET-model ontwikkeld om het gedrag van ondernemers te beïnvloeden. RESET staat voor Regels, Educatie, Sociale druk, Economische incentives en Tools. Een combinatie van deze incentives is nodig om de keuzes van een grote groep ondernemers te beïnvloeden. Daarbij zijn voor iedere ondernemer weer andere instrumenten het meest effectief. De ene ondernemer zal bijvoorbeeld alleen bepaalde keuzes maken als wet- en regelgeving hem of haar daartoe dwingen, en de andere ondernemer heeft economische incentives en kennis nodig om een bepaalde keuze te (durven) maken.

Een andere manier om gedrag te beïnvloeden is beschreven in het 'gedragsveranderingswiel (behaviour change wheel) door Michie et al. (2011). Deze auteurs onderscheiden drie bronnen van gedrag: capability, opportunity en motivation, of in het Nederlands vertaald: weet een persoon hoe hij/zij een bepaalde verandering moet doorvoeren, kan hij/zij en heeft hij/zij de mogelijkheid om een bepaalde verandering door te voeren? En wil hij/zij een bepaalde verandering doorvoeren? Het model van Michie et al. is ontwikkeld voor het beïnvloeden van gezondheidsgedrag van burgers, maar het is voor te stellen dat dergelijke vragen ook belangrijk zijn als men het gedrag van ondernemers en andere actoren in de keten wil beïnvloeden. Daarbij kan het niet weten wellicht verholpen worden door het aanbieden van kennis door (al dan niet interactieve) trainingen, cursussen, studiegroepen en dergelijke (zoals het stellen van duidelijke doelen!), het niet willen door wet- en regelgeving en het niet de mogelijkheid hebben door aanpassingen in beleid of door het ontwikkelen van kennis en technologie die nu nog niet voorhanden is.

Een derde manier van kijken naar gedragsbeïnvloeding wordt in het kort ook wel 'de wortel, de preek en de stok' genoemd. Dit staat voor positieve incentives (de wortel; 'als je dit doet, dan krijg je ...'), voorlichting (de preek; 'het is goed als je dit doet, want ...') en negatieve incentives of dwang (de stok; 'je moet dit doen, of anders ...') om het gedrag te beïnvloeden (Bemelmans-Videc et al., 2003). 
Tabel 3.1 laat zien hoe deze drie manieren van gedragsbeïnvloeding zich ten opzichte van elkaar verhouden. Daarbij is het RESET-model als basis genomen.

Tabel 3.1

Drie verschillende manieren om het gedrag te beïnvloeden

\begin{tabular}{lll} 
RESET (Jansen et al., 2012) & Behaviour Change Wheel & Wortel, Stok en Preek \\
Regels & (Michie et al., 2011) & (Bemelmans-Videc et al., 2003) \\
\hline Educatie & Willen en kunnen & Stok \\
\hline Sociale druk & Weten & Preek \\
\hline Economische incentives & Willen & Wortel \\
\hline Tools & Willen en kunnen & ? \\
\hline
\end{tabular}

In Tabel 3.2 is weergegeven hoe de elementen uit het RESET-model geduid kunnen worden aan de hand van de beoordelingscriteria die zijn beschreven in hoofdstuk 2.

\section{Tabel 3.2}

Beoordeling RESET-model aan de hand van de vijf beoordelingscriteria

\begin{tabular}{|c|c|c|c|c|c|}
\hline & Doeltreffendheid & Overheidskosten & $\begin{array}{l}\text { Controleer- } \\
\text { baarheid }\end{array}$ & $\begin{array}{l}\text { Draagvlak } \\
\text { ondernemers }\end{array}$ & $\begin{array}{l}\text { Toekomst- } \\
\text { bestendigheid }\end{array}$ \\
\hline Regels & ++ & $\begin{array}{l}+/- \text { als er } \\
\text { economische } \\
\text { incentives nodig } \\
\text { zijn om naleving } \\
\text { regels mogelijk te } \\
\text { maken }\end{array}$ & $\begin{array}{l}+/- \text { hangt van de } \\
\text { regel af }\end{array}$ & - & $\begin{array}{l}+/(-) \text { sommige } \\
\text { regels staan } \\
\text { innovatie in de weg }\end{array}$ \\
\hline Educatie & $\begin{array}{l}\text { +/- waarschijnlijk } \\
\text { vooral bij } \\
\text { voorlopers, early } \\
\text { adaptors } \\
\text { Verplichte } \\
\text { cursussen +? }\end{array}$ & $\begin{array}{l}\text { ? } \\
\text { hangt af van type } \\
\text { educatie }\end{array}$ & $\begin{array}{l}+/- \text { je kan } \\
\text { bepaalde cursussen } \\
\text { verplicht stellen } \\
\text { (spuitlicentie) }\end{array}$ & $\begin{array}{l}+/- \text { hangt af van } \\
\text { type ondernemer. } \\
\text { Verplichte } \\
\text { cursussen zullen } \\
\text { niet op prijs gesteld } \\
\text { worden }\end{array}$ & $\begin{array}{l}+ \text { mits educatie } \\
\text { afgestemd wordt } \\
\text { op toekomstige } \\
\text { ontwikkelingen }\end{array}$ \\
\hline Tools & + & $+/-$ & $+/-$ & $\begin{array}{l}++ \text { handelings- } \\
\text { perspectief } \\
\text { belangrijk voor } \\
\text { ondernemers }\end{array}$ & $\begin{array}{l}\text { + mits tools } \\
\text { regelmatig ge- } \\
\text { update worden }\end{array}$ \\
\hline
\end{tabular}




\subsection{Beleidsinstrumenten}

\subsubsection{Algemene beleidsinstrumenten}

In Tabel 3.3 is een overzicht gegeven van de beleidsinstrumenten met voorbeelden die ingezet kunnen worden bij het realiseren van beleidsdoelstellingen.

\section{Tabel 3.3}

Overzicht van beleidsinstrumenten a)

\begin{tabular}{ll} 
Beleidsmaatregelen & Voorbeelden \\
Research \& Development & Technology ontwikkeling en beoordeling \\
\hline Voorlichting en training & Informatie voorzienig, training van vaardigheden \\
\hline Vrijwillige adoptie & Product stewardship, code of practice, certificeringssystemen \\
\hline Regelgeving & Wetgeving, vergunningen, lozingseisen, aanvoereisen \\
\hline Economisch & Zie volgende tabel voor nadere uitwerking
\end{tabular}

a) Gebaseerd op (Gourley and Weaver, 2012)

\section{Research en Development en technologie ontwikkeling}

De overheid investeert op verschillende manieren in de ontwikkeling van nieuwe oplossingen. Dit kan zowel gebeuren in de vorm van fundamenteel onderzoek, pre-competitief onderzoek en onderzoek gericht op het zoeken van oplossingen van maatschappelijke oplossingen. Dit gebeurt door zelf onderzoek te entameren maar ook door het subsidiëren van onderzoek door en met bedrijven (bijvoorbeeld in de vorm van onderzoek binnen de topsectoren).

- Voordeel: de overheid kan onderzoek laten doen naar mogelijkheden die bijdragen aan het realiseren van haar beleidsdoelstellingen.

- Nadelen: het duurt vaak enige tijd voordat dit onderzoek afgerond is, vaak zijn er aanvullende stappen nodig om de doelgroep met de resultaten bekend te maken.

\section{Voorlichting en training}

Eén van de succesfactoren van de Nederlandse landbouw was een sterk OVO-drieluik (OVO=onderzoek, voorlichting en onderwijs). De overheid heeft lang een eigen voorlichtingsapparaat van landbouwvoorlichters gehad dat een rol speelde bij het onder de aandacht brengen van veranderend overheidsbeleid en regelingen. Vanaf eind jaren tachtig was er veel aandacht voor de verbanden binnen het OVO-drieluik. Echter de desintegratie sloeg met de privatisering toe na 1990. Belangrijkste oorzaak van het verminderen van de OVO-relaties was het uiteenlopen van de belangen van overheid en boeren.

Er zijn twee specifieke vormen van voorlichting en training: studiegroepen en demonstratiebedrijven.

- Studiegroepen van ondernemers en peer teaching zijn na en naast de top-down benadering van traditionele voorlichting ontstaan. Doelstelling van studiegroepen is het leren van, voor en met elkaar. Belangrijkste voordeel is het participatieve leren van de deelnemers. Belangrijkste nadeel van studiegroepen is dat het een behoorlijke investering per deelnemer vraagt en de doorstroom van kennis ontwikkeld in deze groepen naar ander groepen ondernemers beperkt is.

- Demonstratiebedrijven/proefboerderijen vervulden een belangrijke rol bij het doen en uitdragen van praktijkgericht onderzoek en hielpen ook om ondernemers in de land- en tuinbouw op te hoogte te stellen van hoe om te gaan met actuele veranderingen in beleid. Informatievoorziening via vakbladen hebben traditioneel een sterke positie in de land en tuinbouw maar digitalisering en gebruik van elektronische informatie en social media neemt ook hier toe. Voor de aanbieders van informatie is het wel nog steeds de uitdaging om hier optimaal gebruik van te maken. 
- Voordeel: niet dwingend.

- Nadelen: vaak wordt maar een beperkte doelgroep bereikt en de opgedane kennis hoeft niet te resulteren in veranderend gedrag of implementatie van gewenste maatregelen.

\section{Vrijwillige adoptie}

Een vorm van vrijwillige adoptie zijn kwaliteitssystemen. Dit zijn private beheerssystemen die er voor zorgen dat bedrijven aan de wettelijke of zelfgekozen bovenwettelijke eisen voldoen. Kenmerkend aan deze systemen is dat ze een interne borging hebben, een objectieve beoordeling en voldoende zelfregulerend en corrigerend vermogen. Ze worden onder meer gebruikt door sectoren die hun eigen verantwoordelijkheid nemen voor het naleven van de wetgeving. Met name bij bovenwettelijke eisen kunnen afnemers van producten besluiten om producten de aan deze bovenwettelijke eisen voldoen extra te belonen.

- Voordelen: draagvlak in de sector vaak groot. Niet verplicht. Geen directe overheidsbemoeienis.

- Nadelen: maar beperkt aantal positieve aspecten/productkenmerken lenen zich voor vermarkten. Gezien de grote export-afhankelijkheid is het voor de afnemer vaak moeilijk om een eventuele meerprijs ook bij de consument betaald te krijgen. Ontbreken van negatieve aspecten hebben alleen tussen bedrijven meerwaarde en niet voor de consument.

\section{Regelgeving}

Wetgeving, vergunningen, lozingseisen, aanvoereisen.

Regelgeving bevat directieve kaders, voor het correct implementeren of toepassen van wetgeving. De strekking van wetgeving wordt nader toegespitst op een specifieke bedrijfstak of samenlevingsaspect. Ook kan de wijze waarop wetgeving geïmplementeerd wordt (tijdelijk) worden bij gestuurd. De eisen waaraan voldaan moet worden en de doelgroepen zijn beschreven.

- Voordeel: verplicht voor de hele doel groep.

- Nadelen: draagvlak in de sector soms laag, het kost tijd om wet- en regelgeving geïmplementeerd te krijgen. Handhaving is soms te beperkt.

\section{Economisch}

De economische/financiële instrumenten worden in de volgende paragraaf (3.2.2) verder uitgewerkt.

\subsubsection{Economische/financiële instrumenten}

Economische instrumenten kunnen worden ingezet met als primair doel kostenterugwinning, of met als doel een sturende werking op het gebruik of emissie. In deze studie gaat het met name om de sturende werking. Tabel 3.4 geeft een overzicht en in de rest van deze paragraaf worden de instrumenten nader toegelicht. 
Tabel 3.4

Overzicht van mogelijke economische/financiële instrumenten

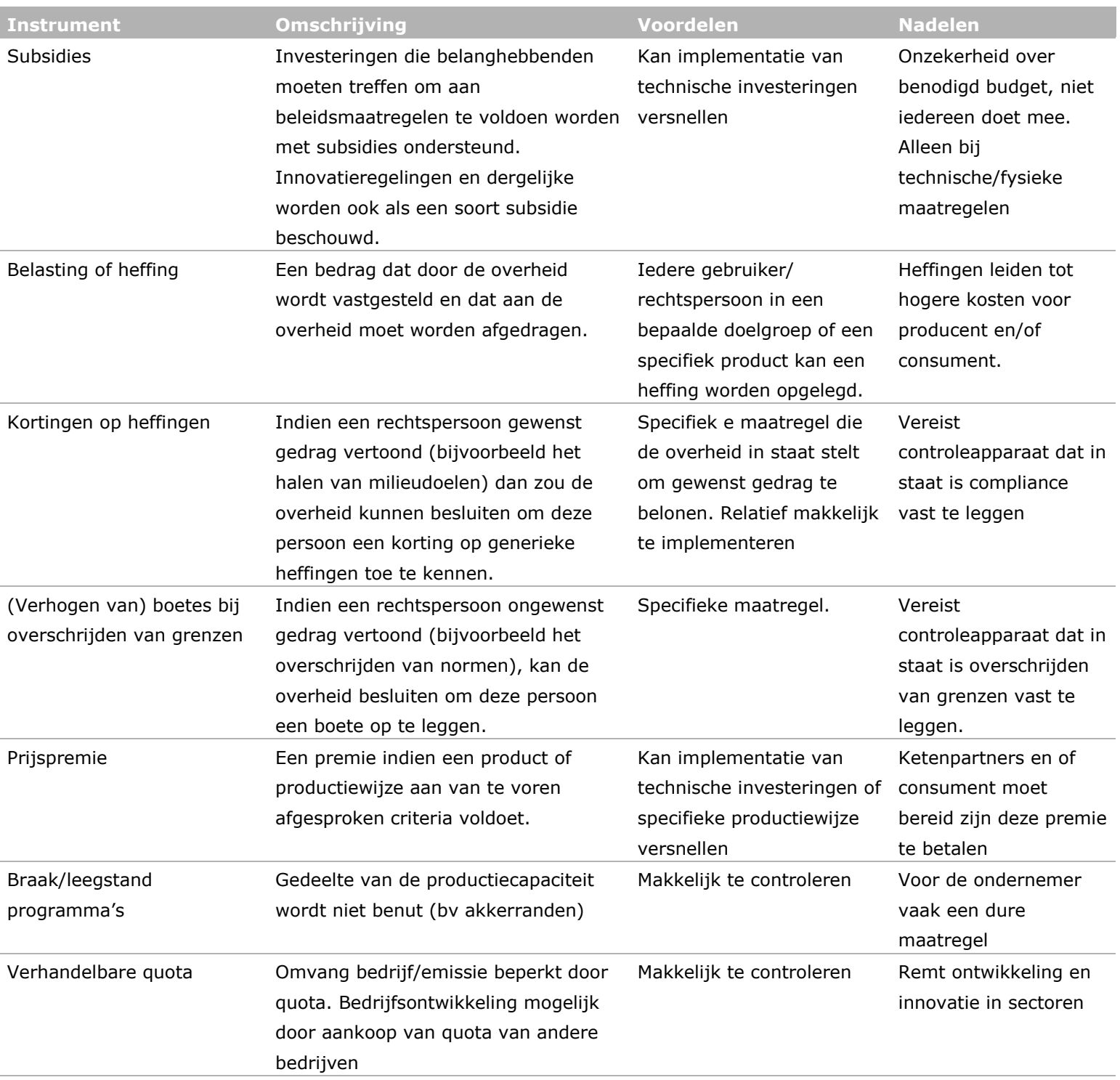

\section{Subsidies}

Indien de overheid bepaald gedrag of bepaalde activiteiten gewenst acht, dan kan de overheid met een subsidieregeling actoren over de streep trekken Vooral als deze gedragingen en activiteiten niet vanzelf tot stand komen (bijvoorbeeld omdat de (gepercipieerde) kosten te hoog zijn). Subsidies zijn vrijwel altijd voorzien van een wettelijke basis en zijn te zien als een vorm van economische regulering. Er worden financiële prikkels gecreëerd om een doelgroep tot gewenst gedrag aan te zetten. Het is daarbij een indirect instrument. De overheid neemt niet zelf de realisatie van een doel op zich, maar heeft hierbij steun nodig van andere actoren. Subsidies worden ingezet om gekozen beleidsdoelen te realiseren.

Subsidies zijn verder stimulerend en niet-repressief van aard (er wordt met subsidies niet direct ge- of verboden). Het zijn specifieke instrumenten, omdat ze over het algemeen op een duidelijk afgebakende doelgroep duiden. Tegenover de toekenning van een subsidie hoeft geen tegenprestatie te staan, althans niet verder dan het voldoen aan de voorwaarden voor de subsidie. Het is daarmee vooral een eenzijdig beleidsinstrument. Het instrument heeft geen dwingend karakter; de te sturen actor blijft de keuze houden om wel of niet op de prikkel te reageren. Tegenover subsidie staat vaak een prestatieverplichting. Om voor subsidie in aanmerking te komen, moet men doorgaans aan specifieke eisen voldoen. Hierbij wordt de subsidie meestal voor een bepaalde periode vastgesteld. De subsidie moet hoog genoeg zijn om het gedrag van de doelgroep werkelijk te beïnvloeden. De hoogte 
hangt af van de kenmerken van de doelgroep (zoals koopkracht en eigen middelen). Subsidie kan ook achteraf worden gegeven, bijvoorbeeld als prijs voor het getoonde gewenste gedrag (KWCJ, 2015).

- Voordelen: Op een positieve manier gedrag beïnvloeden en daarmee een beleidsdoel halen. Door voorwaarden aan subsidieverlening te stellen kun je heel sturend optreden.

- Nadelen: Afhankelijk van soort subsidie kunnen de uitvoeringskosten hoog zijn. Vaak is er maar een beperkt bedrag gereserveerd voor de subsidies. Indien de belangstelling groot is, is er kans dat de subsidiepot snel leeg is, en dat leidt tot frustratie bij aanvragers die niet meer van de subsidie gebruik kunnen maken.

\section{Kader 3.1}

\section{Subsidies binnen Gemeenschappelijk Landbouwbeleid (GLB)}

De herziening van het GLB betreft vooral de eerste pijler, die zich richt op inkomensondersteuning. Kern van de herziening is dat de bedrijfstoeslagen die nu nog variëren in hoogte per boer, meer gelijk worden getrokken. In principe moeten deze toeslagen per regio per 1 januari 2019 gelijk zijn. Daarnaast moeten de boeren die voor de toeslagen in aanmerking willen komen, één of meer vergroeningsmaatregelen toepassen op hun bedrijf.

Plattelandsontwikkeling is een onderdeel van het Europese landbouwbeleid. Elke lidstaat moet een nationaal plan opstellen voor plattelandsbeleid. Nederland heeft het nationaal plattelandsontwikkelingsprogramma (POP3) ingediend bij de Europese Commissie. Dit derde Europese subsidieprogramma voor het ontwikkelen, verduurzamen en innoveren van de agrarische sector in Nederland loopt van 2014 tot 2020.

\section{Vergroening}

Naast de basisbetaling ontvangt elk bedrijf een bedrag per hectare als vergoeding voor het hanteren van bepaalde landbouwmethodes die gunstig verondersteld worden te zijn voor het klimaat en het milieu. De lidstaten moeten hiervoor 30\% van hun nationale enveloppe inzetten. In 2014 werd uitgekeerd voor Markt en prijsbeleid $€ 31 \mathrm{mln}$. voor directe inkomenssteun $€ 806 \mathrm{mln}$. en voor plattelandsbeleid $€ 111 \mathrm{mln}$. (bron RVO). De vergroening met genoemde $30 \%$ is verplicht, maar dit deel is niet onderhevig aan aftopping, 'capping'.

Als vergroeningsmaatregelen zijn, als een 'gekoppelde' verplichting om ook de basisbetaling te ontvangen, door de EC voorgesteld:

- het handhaven van permanent (blijvend) grasland

- diversificatie van gewassen

- ecologische focusgebieden (set aside). Deze dienen ten minste 7\% van de oppervlakte van het bedrijf (exclusief het permanente grasland) te beslaan

\section{Gekoppelde steun als optie}

Lidstaten krijgen de mogelijkheid een deel van de nationale enveloppe gekoppeld aan een specifiek product te besteden. Dit mag hooguit $5 \%$ zijn van de nationale enveloppe wanneer in de lidstaat nu 0 tot $5 \%$ gekoppeld uit wordt betaald of hooguit $10 \%$ wanneer de gekoppelde steun nu nog meer dan $5 \%$ omvat.

Het kan nog meer zijn dan $10 \%$ indien de lidstaat kan aantonen dat dat gerechtvaardigd is. De lidstaat moet goedkeuring ontvangen van de EC voor de gekoppelde betaling, indien de lidstaat meer dan $10 \%$ van de nationale enveloppe wil besteden aan gekoppelde betalingen.

\section{Cross compliance}

De toekenning van alle directe betalingen blijft onderhevig aan de voorwaarde ('cross compliance') dat basisregels ten aanzien van milieu, dierenwelzijn en gezondheid van dieren en planten worden gerespecteerd. Ter vereenvoudiging wordt het aantal regels waaraan moet worden voldaan verminderd. Voorgesteld is ook om de Kaderrichtlijn Water en de Richtlijn Duurzaam gebruik van

Gewasbeschermingsmiddelen op te nemen in de cross-compliancevoorwaarden wanneer deze richtlijnen goed worden toegepast in alle lidstaten en de eisen voor de boeren duidelijk zijn. 


\section{Kader 3.2}

\section{Artikel 68}

In de jaren 2010-2014 wordt gebruik gemaakt van de mogelijkheden die artikel 68 van Verordening $73 / 2009$ biedt om de vermaatschappelijking van de inkomenssteun te bevorderen. Artikel 68 van die verordening verruimt de mogelijkheden om een deel van de nationale enveloppe van de inkomenssteun te herbestemmen om daarmee milieu- en diervriendelijke productiemethoden, kwaliteitslandbouw en het gebruik van risicoverzekeringen te stimuleren.

In het kader van de artikel 68-maatregelen is in 2014 in totaal $€ 12,9 \mathrm{mln}$. betaald ter ondersteuning van de bouw van integraal duurzame stallen, het diervriendelijk produceren, een brede weersverzekering, een vaarvergoeding, de identificatie en registratie van schapen en geiten, en maatregelen voor welzijnsvriendelijke vloeren voor vleeskalverstallen, steun voor instandhouding vezelgewassen, precisielandbouw en duurzame bewaarplaatsen.

\section{Samenvattend}

Hervorming van het landbouwbeleid is een langdurig en ingewikkeld proces waarbij onder andere sterk met de belangen van de verschillende lidstaten rekening wordt gehouden.

Maar een beperkt aantal sectoren krijgen directe inkomenssteun. Dit zijn de akkerbouw, de melkveehouderij en schapenbedrijven. De steun die de vleeskalverhouderij voor 2014 ontving is grotendeels weggevallen doordat deze bedrjiven relatief weinig grond hebben. Aanscherping van de regels van cross-compliance heeft op deze beperkte groep mogelijk gevolgen.

De manoeuvreerruimte voor nationale overheden is beperkt (bijvoorbeeld art. 68). Deze ruimte kan alleen worden gebruikt om vermaatschappelijking van de inkomenssteun te bevorderen.

Belasting of heffing (inclusief kortingen op belasting of heffing)

Er zijn verschillende instrumenten om de kosten voor waterbeheer en waterzuivering ook voor de landbouw te financieren. Dit zijn belastingen en heffingen zoals vastrecht, rioolrecht, verontreinigingsrecht, grondwaterbelasting en omslagen die generiek voor huishoudens en bedrijven geheven worden. Heffingen kunnen bedoeld zijn:

- om de overheid van inkomsten te voorzien (fiscale heffing zoals accijns).

- om het gedrag van de burgers te beïnvloeden (regulerende heffing zoals een milieuheffing).

- hierbij is het doel de activiteit of het gebruik van bepaalde goederen te beïnvloeden, bijvoorbeeld om energiebesparing te bewerkstelligen. Daarom wordt deze vorm van belasting heffen ook wel ecologische belastingheffing of ecotax genoemd.

- om bepaalde overheidstaken te financieren (bestemmingsheffing zoals rioolheffing). Hierbij staat de opbrengst centraal die vervolgens wordt aangewend voor van tevoren vastgestelde milieudoelen. Bekende voorbeelden van bestemmingsheffingen zijn de verontreinigingsheffing watersysteemheffing, en de afvalstoffenheffing (bron: Milieufocus).

- om te differentiëren. Bijvoorbeeld bij verontreinigingsheffing zijn er 2 mogelijkheden: forfaitair of op basis van milieubelasting. Bij deze laatste is de heffing afhankelijk van de hoeveelheid en samenstelling van het water dat wordt geloosd.

Het is niet altijd precies duidelijk tot welke categorie een heffing hoort omdat een heffing verschillende effecten kan hebben. Tarieven kunnen constant, proportioneel, progressief en degressief (regressief) zijn. 


\section{Kader 3.3}

\section{Waarom milieuheffingen?}

De belangrijkste redenen om gebruik te maken van milieuheffingen zijn:

- het zijn bijzonder doeltreffende instrumenten voor de internalisering van externe kosten, dat wil zeggen dat de kosten van milieugebruik en -schade (en het herstel daarvan) direct opgenomen worden in de prijzen van de goederen, diensten of activiteiten die deze kosten en schade veroorzaken; ook dragen zij bij aan de uitvoering van het beginsel 'de vervuiler betaalt' en aan de integratie van economisch en milieubeleid

- ze kunnen zowel consumenten als producenten stimuleren om hun gedrag te veranderen en hulpbronnen 'milieu-efficiënter' te gebruiken, innovatie en structurele veranderingen te bevorderen en te zorgen voor een betere naleving van de regelgeving

- ze kunnen leiden tot meer inkomsten die gebruikt kunnen worden om de milieu-uitgaven te vergroten, en/of om belastingen op arbeid, kapitaal en spaargeld te verlagen

- ze kunnen bijzonder doeltreffende beleidsinstrumenten vormen voor de aanpak van actuele milieuprioriteiten betreffende zulke uiteenlopende bronnen van verontreiniging als verkeersemissies (waaronder de lucht- en zeevaart), afval (bijvoorbeeld verpakking, batterijen) en chemicaliën in de landbouw (bijvoorbeeld pesticiden en kunstmest).

\section{Hebben milieuheffingen effect?}

Het Europees Milieu agentschap heeft een evaluatie van milieuheffingen uitgevoerd. De voornaamste conclusies waren:

- de beoordeelde heffingen hadden een positieve uitwerking op het milieu en bleken in de meeste gevallen kosteneffectief te zijn, binnen de beperkingen van het onderzoek

- voorbeelden van bijzonder doeltreffende heffingen zijn de heffingen op luchtverontreiniging in Zweden, op waterverontreiniging in Nederland en de NOx-heffing en differentiële heffingenstelsels voor voertuigbrandstoffen in Zweden

- regulerende heffingen hebben in het algemeen aanzienlijke positieve milieueffecten mits de heffing voldoende hoog is om maatregelen ter beperking van de verontreiniging te bevorderen

- er wordt een belangrijke bijdrage geleverd aan de milieu-effectiviteit van de bestemmingsheffingen door inkomsten daaruit voor verwante milieu-uitgaven te gebruiken;

- de effecten van milieuheffingen kunnen al binnen relatief korte tijd (2-4 jaar) zichtbaar worden en deze heffingen steken derhalve gunstig af bij andere milieubeleidsmiddelen, hoewel het soms 10-15 jaar kan duren voordat energieheffingen (en sommige regelgeving) een aanzienlijk stimulerend effect sorteren

- het is niet eenvoudig een heffing en de milieueffecten ervan te beoordelen; heffingen maken vaak deel uit van een beleidspakket dat moeilijk in onderdelen uitgesplitst kan worden: het is dan ook niet altijd mogelijk de doeltreffendheid van de heffing op zich duidelijk vast te stellen.

Verder kunnen heffingen vele milieueffecten en bijkomstige voordelen met zich meebrengen waardoor het beleid op vier prioritaire gebieden verbeterd kan worden, namelijk het milieu, innovatie en concurrentievermogen, werkgelegenheid en het belastingstelsel (bron: Europees Milieu Agentschap, 2008).

\section{Kader 3.4}

\section{Heffing op veterinaire antibiotica België (woensdag 29 januari 2014)}

Het Belgische geneesmiddelenagentschap FAGG voert in de loop van 2014 een heffing in op antibiotica voor diergeneeskundig gebruik. Farmaceutische bedrijven zullen per kilogram antibioticum een bijdrage van 1,75 euro moeten betalen, meldt de landbouworganisatie Boerenbond.

Het bedrag wordt vermenigvuldigd met een factor 1,5 wanneer het gaat om voor kritische antibiotica voor de humane sector. In totaal zal dit de FAGG naar schatting ongeveer een half miljoen aan extra inkomsten opleveren.

Dat geld zal worden gebruikt om een centraal datacollectiesysteem te ontwikkelen, de controles bij de dierenartsen te verhogen en het werk van het antibioticakenniscentrum AMCRA (vergelijkbaar met de Nederlandse SDa) te financieren.

\section{Enkele centen}

Veehouders zullen niet veel merken van deze extra heffing, aldus de Boerenbond. De gehanteerde bedragen gelden per kilo antimicrobieel product aanwezig in een bepaald geneesmiddel. De meeste antibiotica in flesvorm bevatten niet meer dan enkele grammen product zodat de geheven taks per verpakking bij de meeste producten beperkt blijft tot enkele eurocenten, aldus de boerenorganisatie. (www.pluimveeweb. nl) 


\section{Heffing op gewasbeschermingsmiddelen in Scandinavië}

Naar aanleiding van een motie van de Tweede Kamerleden Van Gerven en Ouwehand november 2012 is in opdracht van het ministerie van Economische Zaken door SEO een studie uitgevoerd naar de mogelijke effectiviteit van heffingen op bestrijdingsmiddelen. Dit mede naar aanleiding van positieve ervaringen (aanzienlijke verlaging van het gebruik) in Scandinavië met deze maatregel.

\section{De belangrijkste bevindingen uit dit rapport zijn als volgt:}

In Noorwegen bestaat de heffing uit een basisbedrag van 3,5 euro per hectare vermeerderd met een factor afhankelijk van de klasse waarin het gewasbeschermingsmiddel is ingedeeld. In Zweden bedraagt de heffing 2 euro per kilo actieve stof. In Denemarken bedraagt de heffing tussen de 54\% en 33\%, afhankelijk van het soort gewasbeschermingsmiddel. Het blijkt dat heffingen in deze landen onderdeel van bredere pakketten aan maatregelen zijn, gericht op de vermindering van het gebruik van gewasbeschermingsmiddelen. Deze brede 'maatregelpakketten' bestaan in Noorwegen bijvoorbeeld uit fiscale tegemoetkomingen, informatie en advies, onderzoek en ontwikkeling, en subsidies. In Denemarken is, naast de heffing, een middelenreductieprogramma gelanceerd en heeft men de grondbelasting in de landbouw afgeschaft. Het gebruik van middelen is ten tijde van deze beleidspakketten afgenomen (Noorwegen sinds 1999 en Denemarken sinds 1996), maar deze afname kan niet zomaar aan de heffingen worden toegeschreven. Het ontbreekt dan ook aan wetenschappelijke gefundeerde evaluaties van deze heffingen. Mede door het ontbreken van een benchmark is het moeilijk om het effect van een heffing op het gebruik te isoleren. (EZ, 2013).

- Voordeel: algemeen geldend voor grote groep bedrijven. In een passende vorm zou een heffing kunnen bijdragen aan het 'vervuiler betaalt'-principe.

- Nadelen: er wordt bij de een aantal forfaitaire heffingen geen onderscheid gemaakt naar de mate van vervuiling door de individuele bedrijven. Bij een aantal heffingen is er sprake van een gedifferentieerde heffing.

\section{Boetes}

Boeten kunnen opgelegd worden bij overtreden van regelgeving zoals het overschrijden van grenzen.

- Voordeel: draagt bij aan het 'vervuiler betaalt'-principe.

- Nadelen: handhaafbaarheid en hoogte van de boetes wel of niet in overeenstemming met de ernst van het delict/ kosten die gemaakt moeten worden. Bewijsvoering vaak lastig.

\section{Prijspremie}

De producent ontvangt een premie op de prijs van zijn product indien het product of de productiewijze aan specifieke aanvullende eisen voldoet. Voorbeelden zijn tomaten waarbij geen gebruik wordt gemaakt van bepaalde gewasbeschermingsmiddelen en die daardoor geschikt zijn voor export naar landen/afzetkanalen die bovenwettelijke eisen stellen aan producten, zoals bijvoorbeeld supermarkten in Duitsland.

- Voordeel: sterke prikkels vanuit de markt om gewenst gedrag te vertonen.

- Nadeel: er zijn maar een beperkt aantal productkenmerken waarbij dit soort premies in de markt te realiseren zijn.

\section{Braak-/leegstandsprogramma's}

Braak en leegstandprogramma's kunnen een aantal doelen dienen:

a. het uit productie nemen van capaciteit betekent ook minder gebruik van mogelijk schadelijke stoffen

b. strategisch aangelegde stroken kunnen als barrière fungeren waardoor de vervuiling vanuit aangrenzende percelen wordt beperkt.

- Voordeel: snelle reductie in gebruik van emitterende stoffen.

- Nadelen: vaak duur en weinig bereidheid van ondernemers om dit zonder adequate vergoeding toe te passen.

\section{Verhandelbare quota}

Het toepassen van quota is een veel toegepast instrument om de groei in de productie/emissie te beperken. Voorbeelden: Dierrechten, melkquotum (afgeschaft in 2015), fosfaatrechten (melkveehouderij). Bedrijven krijgen vaak een quotum toebedeeld op basis van historische productie. 
Als bedrijven willen groeien zullen ze aanvullende quota moeten verwerven. De overheid heeft de mogelijkheid om bij verhandeling een gedeelte van de quota te korten (waardoor productiecapaciteit uit de markt wordt genomen). Quota vertegenwoordigen een economische waarde. Bij het stelsel voor dierrechten ligt het aangrijpingspunt eerder in de keten dan bij productierechten als fosfaatquota: niet bij de productie van mest, maar bij de hoeveelheid vee die een bedrijf aanhoudt. Een gerichte keuze voor het aangrijpingspunt van de handel kan mede bepalend zijn voor de effectiviteit van het systeem.

\section{Kader 3.6}

'Ik denk dat de verhandelbare emissierechten een goed voorbeeld zijn van een beleidsinnovatie die de laatste jaren veel impact heeft gehad, in die zin dat de innovatie wijd verspreid is, maar ook de potentie heeft milieuwinst te brengen. Het past ook in het patroon dat ik net beschreef: het idee is eigenlijk al heel oud en stamt uit academische publicaties uit de jaren vijftig van de vorige eeuw. In de praktijk ging het pas leven in de jaren zeventig, toen fabrieken in de VS vroegen of ze de emissierechten die in hun vergunningen waren opgenomen ook flexibel mochten interpreteren, zodat ze ingezet mochten worden op de locatie waar ze het meest nodig waren. En vanuit de VS is die aanpak ook in andere landen terechtgekomen: verhandelbare emissierechten zijn nu voor de Europese Unie hét beleidsinstrument op het vlak van klimaat. Maar dat is zeker niet zonder slag of stoot gegaan, en ook toeval speelt hierin een zekere rol.'

Uit een interview met OU-hoogleraar Milieubeleid Dave Huitema, juli 2014. (www.ou.nl)

- Voordelen: de maximale productiecapaciteit/emissie staat vast en kan direct gestuurd worden via aanpassingen van het beleid (bijvoorbeeld korten aankoop).

- Nadelen: kosten voor investering in quota kunnen substantieel zijn en hebben direct invloed op de investeringscapaciteit van bedrijven (middelen zijn dan bijvoorbeeld niet beschikbaar voor investeringen in milieu innovaties). 


\section{$4 \quad$ Ketenbeschrijvingen}

In dit hoofdstuk wordt inzicht gegeven in de verschillende ketens waarin gebruik gemaakt wordt van nutriënten, gewasbeschermingsmiddelen en biociden, diergeneesmiddelen, en zware metalen. Het is een korte beschrijving uit welke schakels de ketens zijn opgebouwd.

De beschrijving van de ketens zal zich beperken tot landelijk niveau en tot de land- en tuinbouwsectoren waar de grootste aanvoer en emissies van schadelijke stoffen naar het water plaatsvinden. Informatie over in- en exportvolumes is te vinden op de Agrimatie-website (www.agrimatie.nl). De gegevens rond mestproductie en mestafzet zijn afkomstig van de website www.monitoringmestmarkt.nl.

\section{Regionale verdeling}

Meer informatie over de regionale verdeling binnen de verschillende sectoren is te vinden in Bijlage 3 (www.agrimatie.nl).

Voor de afzet van producten wordt in dit hoofdstuk alleen aandacht besteed aan bestemming van producten van landbouwbedrijven in Nederland. Doorvoer van producten wordt buiten beschouwing gelaten omdat dit niet resulteert in emissie van primaire bedrijven in Nederland.

In Tabel 4.1 zijn per keten de stoffen vermeld die naar het water (grondwater of oppervlaktewater) kunnen emitteren.

\section{Tabel 4.1}

Emissies van nutriënten, gewasbeschermingsmiddelen en biociden, diergeneesmiddelen en zware metalen naar water in verschillende productieketens

\begin{tabular}{|c|c|c|c|c|}
\hline Keten & Nutriënten a) & $\begin{array}{c}\text { Gewasbescherming } \\
\text { en biociden }\end{array}$ & $\begin{array}{l}\text { Diergenees- } \\
\text { middelen }\end{array}$ & Zware metalen \\
\hline $\begin{array}{l}\text { Akkerbouw en } \\
\text { opengrondstuinbouw }\end{array}$ & $\sqrt{ }$ & $\sqrt{ }$ & & $\sqrt{ }$ \\
\hline Glastuinbouw & $\sqrt{ }$ & $\sqrt{ }$ & & $\sqrt{ }$ \\
\hline $\begin{array}{l}\text { Intensieve veehouderij } \\
\text { (varken, pluimvee en vleeskalf) }\end{array}$ & $\sqrt{ }$ & & $\sqrt{ }$ & $\sqrt{ }$ \\
\hline $\begin{array}{l}\text { Grondgebonden veehouderij } \\
\text { (melkvee) }\end{array}$ & $\sqrt{ }$ & $\sqrt{ }$ & $\sqrt{ }$ & \\
\hline
\end{tabular}

a) De intensieve veehouderij is verantwoordelijk voor een grote aanvoer van mineralen en nutriënten. De aanvoer van nutriënten wordt bij de akkerbouw beschreven en de manieren van mestafzet worden bij de intensieve veehouderij beschreven. Mestaanwending is de belangrijkste bron van emissies in het milieu; deze worden beschreven in de keten akkerbouw en opengrondtuinbouw 


\subsection{Akkerbouw en opengrondtuinbouw}

De akkerbouw is geconcentreerd in het Noordelijk Zeekleigebied, de IJsselmeerpolders en het Zuidwestelijk Zeekleigebied. In de Veenkoloniën worden van oudsher veel zetmeelaardappelen geteeld, en in het daarboven gelegen Oldambt veel granen. Beide gewassen zijn extensiever en leveren vaak minder geld op dan bijvoorbeeld de poot- en consumptieaardappelen.

De vollegrondgroenteteelt is geconcentreerd in West-Friesland, Zuid-Hollandse Eilanden, West-Brabant en Noord-Limburg. De bloembollenteelt zit vooral in het duinzandgebied tussen Wassenaar en Texel, in West-Friesland en de Noord-Oost-Polder. De fruitteelt bevindt zich vooral in het Rivierengebied en in Zuid-Beveland. De boomkwekerij zit vooral in Boskoop, Zundert en Noord-Limburg.

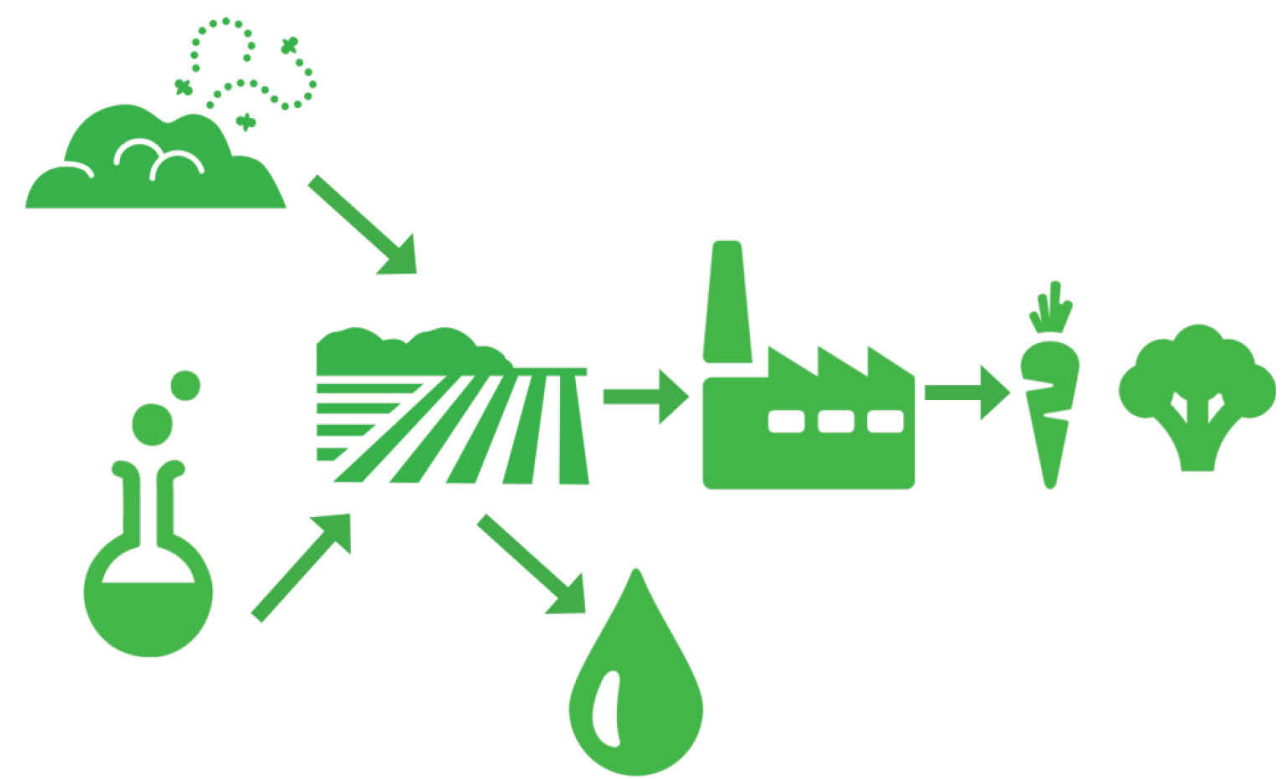




\begin{tabular}{|c|c|}
\hline & $\begin{array}{l}\text { Gebruik van kunstmest, gewasbeschermingsmiddelen en biociden. } \\
\text { Grondstoffen zijn gedeeltelijk afkomstig uit het buitenland (mijnbouw) of worden } \\
\text { samengesteld in chemische fabrieken. Via enkele tientallen toeleveringsbedrijven } \\
\text { worden de grondstoffen geleverd aan akkerbouwers en opengrondtuinders. }\end{array}$ \\
\hline & $\begin{array}{l}\text { Aanvoer van drijfmest, veelal afkomstig uit intensieve veehouderijbedrijven in } \\
\text { Noord-Brabant, Limburg en Gelderland en toegepast op akkerbouwbedrijven in } \\
\text { Zuidwestelijk Kleigebied en Flevoland. }\end{array}$ \\
\hline & $\begin{array}{l}\text { Ongeveer } 15.000 \text { hoofdberoepsbedrijven met veelal hoogproductieve } \\
\text { teeltsystemen op een areaal van circa } 650.000 \text { ha. De bedrijven zijn meestal } \\
\text { gespecialiseerd op een of enkele gewassen. }\end{array}$ \\
\hline & $\begin{array}{l}\text { De geproduceerde granen, suikerbieten, aardappelen, bloembollen, groenten, } \\
\text { fruit en boomkwekerijproducten gaan naar de verwerkende industrie of naar } \\
\text { handelshuizen. }\end{array}$ \\
\hline & $\begin{array}{l}\text { De verwerkende industrie en de handelshuizen verkopen hun producten aan } \\
\text { supermarkten en diverse andere afnemers in binnenland en buitenland. } \\
\text { Ruim } 50 \% \text { van de productie wordt geëxporteerd met een geschatte } \\
\text { handelswaarde van } € 3 \text { mld. per jaar. }\end{array}$ \\
\hline \multirow[t]{2}{*}{$\begin{array}{l}\text { Afvoer } \\
\text { restanten en } \\
\text { verpakkingen }\end{array}$} & $\begin{array}{l}\text { Aangebroken verpakkingen en moeilijk schoon te spoelen verpakkingen van } \\
\text { gewasbeschermingsmiddelen kunnen gratis worden ingeleverd als Klein } \\
\text { Gevaarlijk Afval bij gemeentelijke KCA-depots. } \\
\text { Via het TOPPS Nederland project (Train Operators to Promote best Practices and } \\
\text { Sustainability), groeit de aandacht voor erfemissies. Voor de zuivering van } \\
\text { spoelwater wordt speciale apparatuur aangeboden. }\end{array}$ \\
\hline & $\begin{array}{l}\text { De primaire productie (akkerbouw en opengrondtuinbouw) is de belangrijkste } \\
\text { ketenschakel voor de emissie van gewasbeschermingsmiddelen naar het } \\
\text { oppervlaktewater. De toeleverende schakels (fabrikanten en toeleveranciers) } \\
\text { werken met gesloten verpakkingen. De afnemende schakels hebben alleen met } \\
\text { residuen op het product te maken en dan gaat het in de meeste gevallen om } \\
\text { minieme hoeveelheden (<1 mg/kg product). } \\
\text { Gewasbeschermingsmiddelen kunnen via uitspoeling via drains en afspoeling van } \\
\text { percelen in het oppervlaktewater komen. De belangrijkste emissieroutes van de } \\
\text { primaire productie zijn echter drift (verwaaiing van spuitdruppels naar sloten en } \\
\text { vaarten) en erfemissie. De belangrijkste opties voor driftbeperking zijn driftarme } \\
\text { spuitdoppen c.q. spuitsystemen en aanleg van teeltvrije zones of bloemenstroken } \\
\text { langs watervoerende sloten. De belangrijkste opties voor beperking van } \\
\text { erfemissies zijn zuivering van spoelwater, condenswater en dergelijke. }\end{array}$ \\
\hline
\end{tabular}




\subsection{Glastuinbouw}

De glastuinbouw in Nederland is geconcentreerd in de drie Greenports: Westland/Oostland, Aalsmeer e.o. en Venlo e.o. Daarnaast zijn het afgelopen decennium nieuwe concentraties ontstaan in de Wieringermeer (AgriportA7) en de Noord-Oost-Polder (Luttelgeest). Het vestigen in concentratiegebieden heeft als voordeel dat hechte netwerken -economische clusters- bestaan tussen toeleveranciers, glastuinders en afnemers.

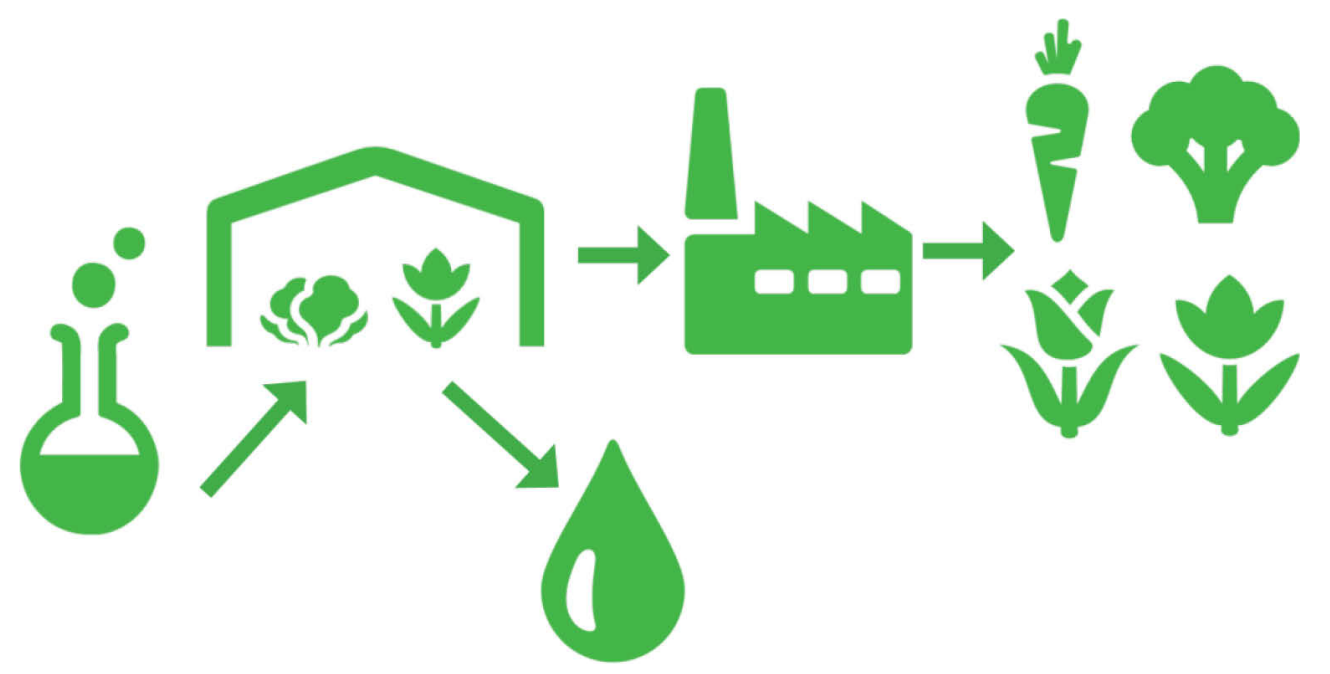




Gebruik van alle meststoffen, gewasbeschermingsmiddelen en biociden.
Grondstoffen zijn gedeeltelijk afkomstig uit het buitenland (mijnbouw) of worden
samengesteld in chemische fabrieken. Via enkele tientallen toeleveringsbedrijven
worden de grondstoffen geleverd aan glastuinders.
$\begin{aligned} & \text { Ongeveer } 3.500 \text { bedrijven met hoogproductieve teeltsystemen op een areaal van } \\ & \text { circa } 9.500 \text { ha. De bedrijven zijn bijna altijd gespecialiseerd op een of enkele } \\ & \text { gewassen. }\end{aligned}$

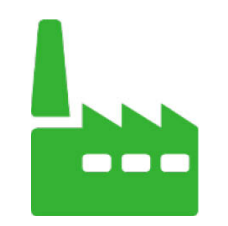

De geproduceerde groenten, bloemen en planten gaan via telersverenigingen of handelshuizen het handelskanaal in.

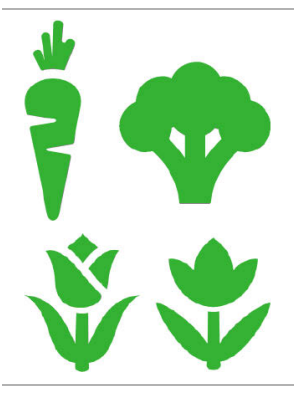

De telersverenigingen en handelshuizen verkopen hun producten aan supermarkten en diverse andere afnemers in binnenland en buitenland. Ongeveer $75 \%$ van de productie wordt geëxporteerd met een geschatte handelswaarde van $€ 6$ miljard per jaar.

Afvoer

Aangebroken verpakkingen en moeilijk schoon te spoelen verpakkingen van gewasbeschermingsmiddelen kunnen gratis worden ingeleverd als Klein Gevaarlijk Afval bij gemeentelijke KCA-depots.

Bij de teelt op substraat kunnen te hoge concentraties aan $\mathrm{NaCl}$ in de voedingsoplossing ontstaan. In zulke gevallen wordt het afvalwater, inclusief nutriënten en gewasbeschermingsmiddelen, geloosd op het riool of bij afwezigheid daarvan op het oppervlaktewater.

De primaire productie (glastuinbouw) is de belangrijkste ketenschakel voor de emissie van gewasbeschermingsmiddelen naar het oppervlaktewater. De toeleverende schakels (fabrikanten en toeleveranciers) werken met gesloten verpakkingen. De afnemende schakels hebben alleen met residuen op het product te maken en dan gaat het in de meeste gevallen om minieme hoeveelheden ( $<1 \mathrm{mg} / \mathrm{kg}$ product). De belangrijkste emissieroute van de glastuinbouw is lozing van ongezuiverd afvalwater op het oppervlaktewater of op het riool. De belangrijkste optie voor deze emissieroute is zuivering van afvalwater op de bedrijven. Over het tijdstip van invoering hiervan wordt al enkele jaren onderhandeld. De zorgwekkende financiële situatie op meer dan de helft van de glastuinbouwbedrijven vormt een obstakel voor een snelle invoering. 


\subsection{Intensieve veehouderij}

In deze paragraaf worden de productieketens van varkens, pluimvee en vleeskalveren beschreven.

De varkenshouderij is vooral te vinden op de zandgronden in het zuiden en oosten van Nederland. Dieren werden steeds intensiever gehouden en dus een hogere productie per oppervlakte-eenheid. De matige kwaliteit van de grond leent zich niet voor grootschalige grondgebonden activiteiten. Het verbouwen van mais vindt nog wel plaats.

De pluimveehouderij is van oudsher geconcentreerd op de zandgronden in het midden (Veluwe), zuiden en oosten van Nederland. Dat geldt vooral voor de leghennenhouderij. De vleeskuikenhouderij is meer verspreid over Nederland.

De vleeskalverhouderij is in ruimtelijke zin sterk geconcentreerd op de Veluwe. Enkele minder grote clusters van kalverbedrijven zijn te vinden in de provincie Noord-Brabant, zoals in de grensstreek ten zuiden van Breda.

Het ruimtebeslag van de kalversector is relatief klein. In 2013 was ruim twee derde van de 900.000 vleeskalveren gehuisvest in de provincies Gelderland (46\% van de vleeskalveren) en Noord-Brabant (21\%). Overijssel volgt als derde provincie met een aandeel van $15 \%$. De kalverhouderij is in Overijssel niet alleen kleiner in omvang maar ruimtelijk ook meer gespreid dan in de twee andere provincies (bron: www.agrimatie.nl).

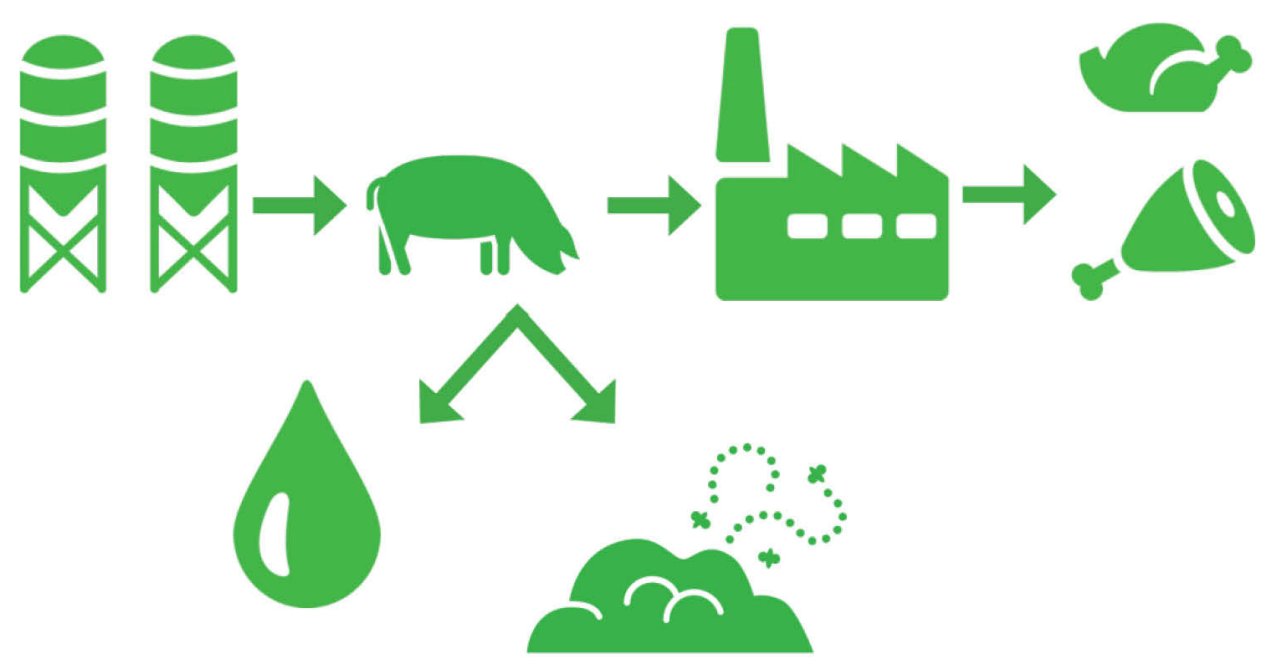




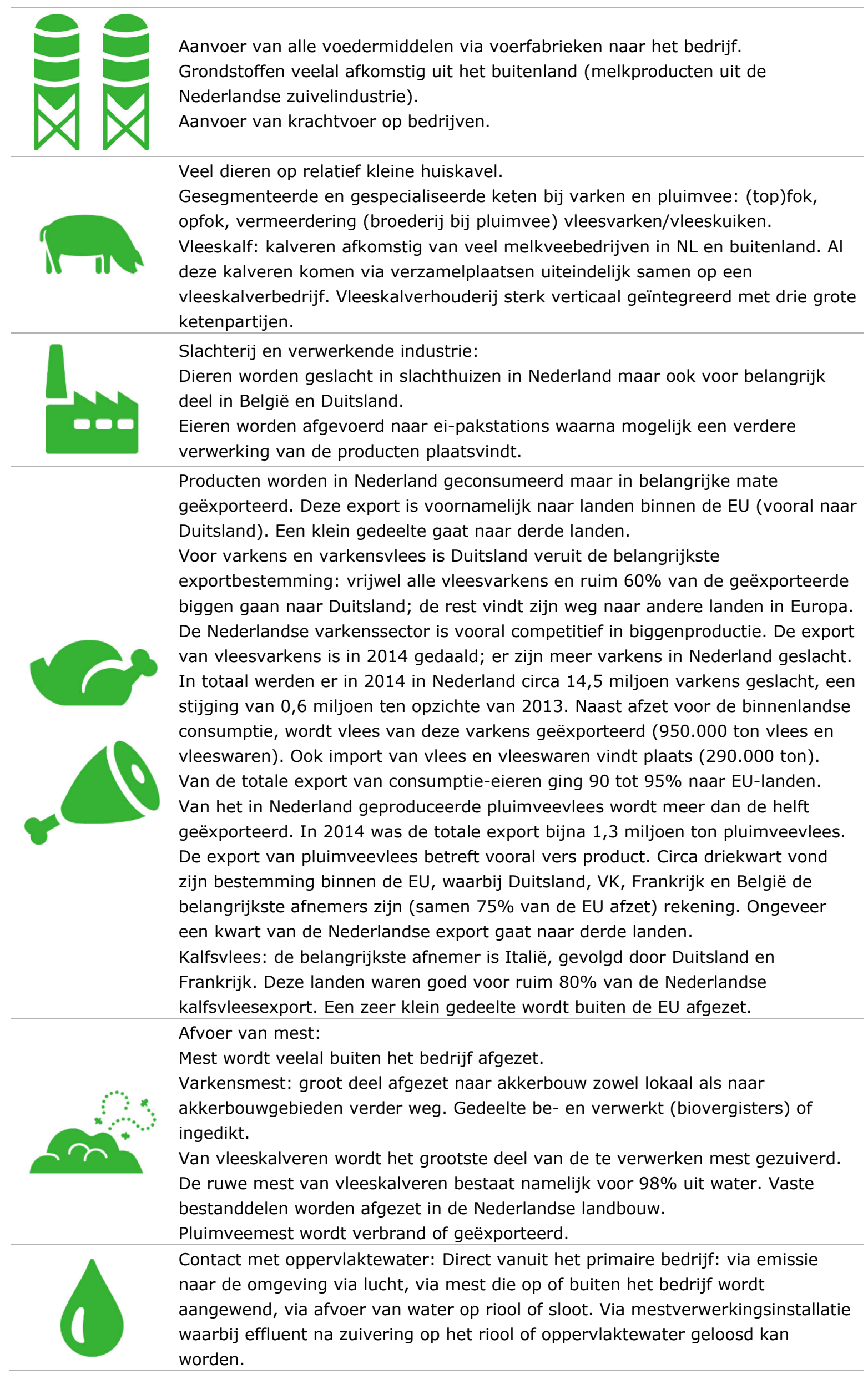




\subsection{Melkveehouderij}

De melkveehouderij is breed verspreid over het landelijk gebied, maar het economische belang ervan binnen een regio wisselt sterk. Clusters, waarin de melkveehouderij in economische zin dominant aanwezig is, zijn omvangrijk en gelegen in Utrecht, Zuid-Holland, Friesland en delen van zuidelijk en oostelijk Nederland. In akkerbouwregio's als Limburg, Zeeland, West-Brabant, Noord-Holland, Flevoland en de Veenkoloniën speelt de melkveehouderij een betrekkelijk kleine rol (bron: www.agrimatie.nl).

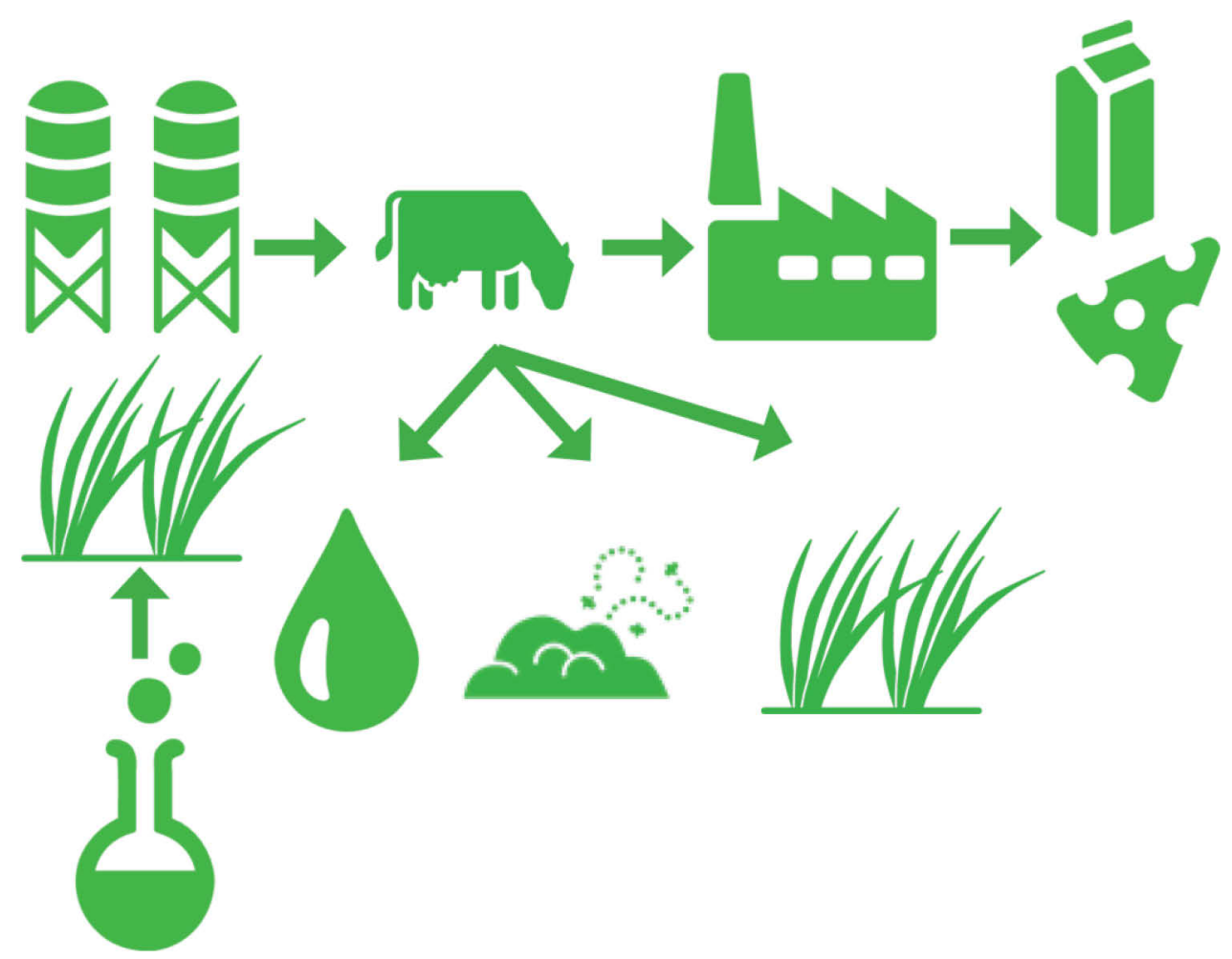




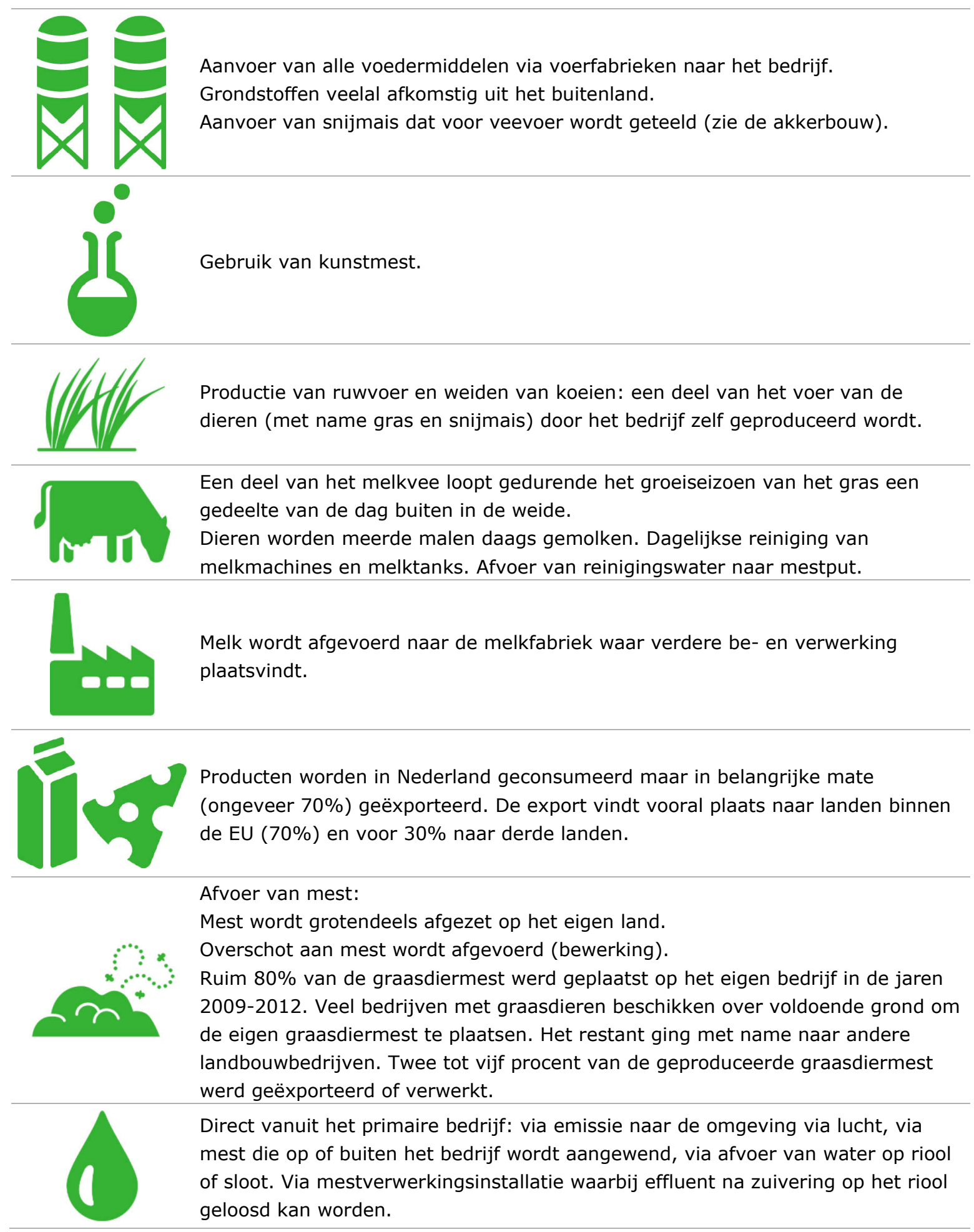




\section{Aan- en afvoer van stoffen}

In dit hoofdstuk wordt per stofcategorie een indicatie gegeven van de omvang van de emissies van vervuilende stoffen vanuit de landbouw. Hierbij is vooral aandacht besteed aan de stoffen die het meest relevant zijn voor de waterkwaliteit.

\section{$5.1 \quad$ Nutriënten}

\section{Oorsprong van nutriënten in het milieu}

Uit de Programmatische Aanpak Stikstof PAS-evaluatie uit 2013 blijkt het volgende:

- Van alle stikstofdepositie is twee derde ammoniak en een derde stikstofoxiden.

- Alle landbouwbedrijven bij elkaar leveren $40 \%$ van de totale landelijke stikstofdepositie door de uitstoot van ammoniak. Er slaat 15 tot $20 \%$ van deze ammoniakemissie neer binnen een straal van 10 kilometer rond het bedrijf, met soms een belangrijke impact op natuurgebieden.

- Van de stikstofdepositie in Nederland komt 30\% uit buitenlandse bronnen.

- Het verkeer is verantwoordelijk voor $7 \%$ van de totale stikstofdepositie.

- Overige bedrijven (industrie, energie en afval) en huishoudens zijn voor $23 \%$ verantwoordelijk voor de totale stikstofdepositie. (Planbureau voor de Leefomgeving, 2014)

Tabel 5.1

Stikstofemissie in 2010 (kiloton/jaar)

\begin{tabular}{lr} 
& $N^{2}$ \\
Afkomstig uit: & 55,8 \\
\hline Stallen & 2,9 \\
\hline Mestopslagen (buiten stal) & \\
\hline Ontstaan bij: & 1,9 \\
\hline Beweiding (koeien, schapen) & 40,1 \\
\hline Bemesten land met dierlijke mest & 10,2 \\
\hline Bemesten met kunstmest & $\mathbf{1 1 0 , 9}$ \\
\hline Totaal & $\mathbf{1 8 , 2}$ \\
\hline
\end{tabular}

Bron: Beoordeling Programmatische Aanpak Stikstof; de verwachte effecten voor natuur en vergunningsverlening, blz. 32; Beleidsstudie

Planbureau voor de Leefomgeving, Den Haag, 2014

In Tabel 5.1 staan de stikstofemissies van de landbouwsector voor het basisjaar 2010. In 2013 was de totale ammoniakemissie van de Nederlandse land- en tuinbouw gestegen tot 113 kiloton, waarvan ruim 49 kton uit de melkveehouderij, 23 kton uit de varkenssector en bijna 12 kton uit de pluimveesector.

Productie en afzet van mest

De mest- en mineralenproductie van de Nederlandse veestapel staan in Tabel 5.2 en 5.3 en de afzet van kunstmest in Tabel 5.4 . 
Tabel 5.2

Mestproductie door de Nederlandse veestapel, definitieve cijfers 2014

\begin{tabular}{|c|c|c|}
\hline & Dunne mest & Vaste mest \\
\hline \multicolumn{3}{|c|}{ mln. kg } \\
\hline Rundvee, exclusief vleeskalveren & 54.632 & 576 \\
\hline Varkens & 11.424 & - \\
\hline Pluimvee & 0 & 1.500 \\
\hline Pelsdieren en konijnen & 155 & 16 \\
\hline Paarden en pony's a) & 366 & 528 \\
\hline Gehele veestapel & 71.048 & 3.041 \\
\hline
\end{tabular}

a) De weidemest van schapen, paarden en pony's is gerekend als dunne mest

Bron: LEI,2015 (www.monitoringmestmarkt.nl)

\section{Tabel 5.3}

Mineralenproductie door de Nederlandse veestapel, definitieve cijfers 2014

\begin{tabular}{|c|c|c|c|}
\hline & $\mathrm{N}$-uitscheiding & $\mathbf{P}_{2} \mathbf{O}_{5}$ & $\mathrm{~K}_{2} \mathrm{O}$ \\
\hline & mln. kg & & \\
\hline Rundvee, exclusief vleeskalveren & 289,1 & 90,6 & 394,6 \\
\hline Vleeskalveren & 18,6 & 6,4 & 14,5 \\
\hline Varkens & 98,7 & 38,8 & 63,5 \\
\hline Pluimvee & 60,1 & 27,7 & 28,3 \\
\hline Schapen en geiten & 11,6 & 4,4 & 18,2 \\
\hline Pelsdieren en konijnen & 2,4 & 1,4 & 1,1 \\
\hline Paarden en pony's & 6,3 & 2,3 & 7,9 \\
\hline Gehele veestapel & 486,7 & 171,7 & 528,0 \\
\hline
\end{tabular}

Bron: LEI Wageningen UR (www.monitoringmestmarkt.nl)

\section{Afzet van mest}

\section{Graasdiermest}

Ruim $80 \%$ van de graasdiermest werd geplaatst op het eigen bedrijf in de jaren 2009-2012. Veel bedrijven met graasdieren beschikken over voldoende grond om de eigen graasdiermest te plaatsen. Het restant ging met name naar andere landbouwbedrijven. Twee tot vijf procent van de geproduceerde graasdiermest werd geëxporteerd of verwerkt.

\section{Pluimveemest}

Deze mest wordt geëxporteerd of verwerkt (korrelen of verbranden). Beiden zijn even belangrijk. Ongeveer $5 \%$ van de pluimveemest werd geplaatst op akkerbouwbedrijven. Droge pluimveemest wordt vaak over grotere afstanden vervoerd naar akkerbouwbedrijven in het buitenland ruim de helft van de totaal geproduceerde hoeveelheid wordt geëxporteerd naar Duitsland en, in mindere mate, naar België en Frankrijk. In de situatie van 2011 wordt maar een klein deel van de Nederlandse pluimveemest op het eigen bedrijf afgezet (3\%). Veertien procent van de mest wordt verder verwerkt, onder andere tot mestkorrels. Sinds 2008 is de biomassacentrale (BMC Moerdijk) in gebruik genomen voor de verbranding van pluimveemest. Circa een derde wordt verbrand door de biomassacentrale in Moerdijk (www.agrimatie.nl).

\section{Varkensmest}

De plaatsing van varkensmest in de Nederlandse landbouw is in een jaar tijd met meer dan een kwart gedaald, onder andere door stringentere fosfaatgebruiksnormen. De mestproductie was lager en er werd meer mest geëxporteerd. Het grootste deel van de varkensmest wordt afgezet op andere bedrijven in de eigen regio. Door de lagere mestproductie is de niet geplaatste hoeveelheid varkensmest in 2012 een derde lager dan in 2011 en komt daarmee uit op bijna $4 \mathrm{mln}$. kg fosfaat ( $9 \%$ 
van de productie). Mestverwerking was in 2009-2011 rond de 0,5 mln. $\mathrm{kg}$ fosfaat; door afrondingen op hele waarden kwam die juist wel of juist niet op $1 \mathrm{mln}$. $\mathrm{kg}$ uit.

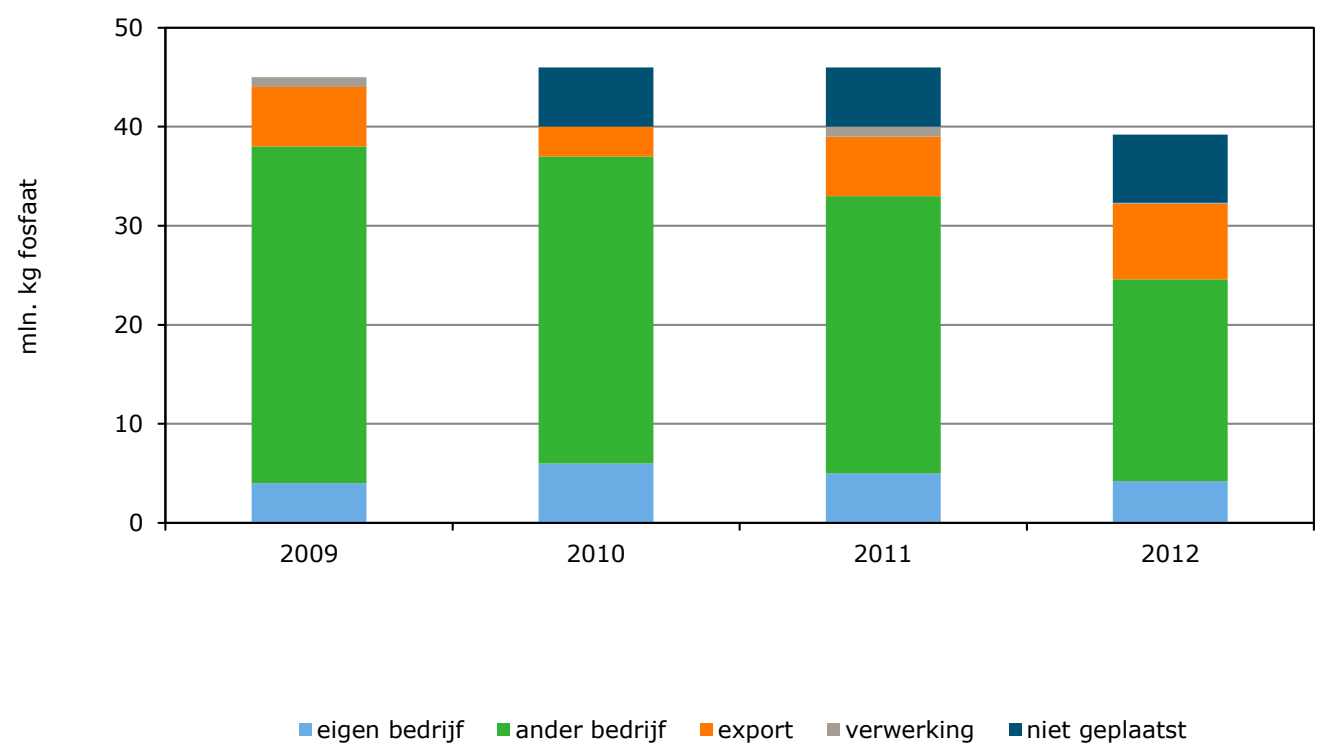

Figuur 5.1 Nationale fosfaatplaatsing van varkensmest, $\mathrm{mln} . \mathrm{kg}, 2009-2012 \mathrm{a}$ )

a) Beschikbaar vanaf 2009

Bron: CBS Landbouwtelling, bewerking LEI Wageningen UR met MAMBO-berekeningen

Overige dierlijke mest (mest van vleeskalveren)

Zowel het Centraal Veehouderijgebied als het Zuidelijk Veehouderijgebied produceerden in 2012 ongeveer een derde van de nationale productie van overige dierlijke mest. Overige dierlijke mest betreft vooral mest van vleeskalveren en daarvan is het Centraal Veehouderijgebied een grote producent. In de regio's waar de meeste overige dierlijke mest wordt geproduceerd (Zuidelijk Veehouderijgebied en het Centraal Veehouderijgebied) wordt ook het meeste geplaatst. Ruim de helft van de nationale plaatsing vindt plaats in deze twee regio's. Het Noordelijk Weidegebied en het Oostelijk Veehouderijgebied plaatsen beide ongeveer $15 \%$ van de nationale hoeveelheid.

\section{Tabel 5.4}

\section{Afzet van kunstmeststoffen in 2013}

Kunstmestsoort

Bron: LEI Wageningen UR (www.monitoringmestmarkt.nl)

\subsubsection{Trends in N- en P-emissie}

De emissies van $\mathrm{N}$ en $\mathrm{P}$ naar water blijven gestaag afnemen als gevolg van ingezet beleid (Duijnhoven et al., 2015). Uit hun onderzoek blijkt dat voor heel Nederland in 2014 voor N-totaal bijna 50\% van de waterlichamen als 'goed' is beoordeeld. Voor P-totaal is dit percentage $45 \%$.

De meeste waterlichamen laten een dalende trend zien, echter er zijn een aantal waterlichamen waarbij een stijgende trend zichtbaar is. 

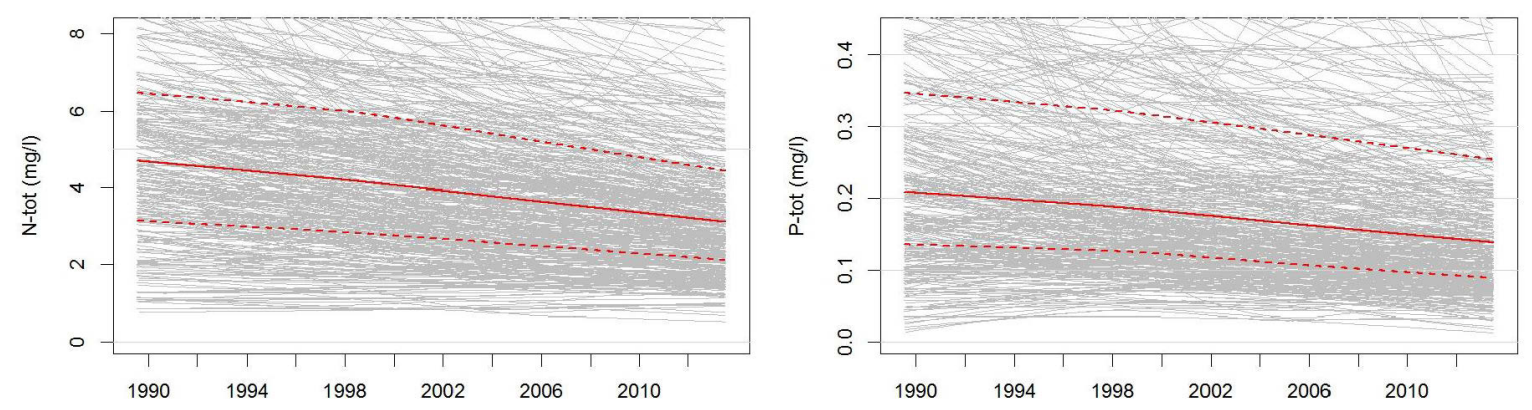

Figuur 5.2a en 5.2b Geaggregeerde LOWESS-trendlijn en de 25 en 75-percentiel LOWESStrendlijnen (gestippeld) voor $\mathrm{N}$-totaal en P-totaal a)

a) De LOWESS-trendlijnen voor de individuele meetlocaties zijn op de achtergrond in grijs weergegeven

Bron: Duijnhoven et al. (2015)

\subsubsection{Emissies van nutriënten vanuit de glastuinbouw}

De stikstof- en fosforemissie per hectare glastuinbouw bedraagt $2.201 \mathrm{~kg} \mathrm{~N} / \mathrm{ha} / \mathrm{jr}$ en 330,1 kg P/ha/jr voor substraatteelt en $288 \mathrm{~kg} \mathrm{~N} / \mathrm{ha} / \mathrm{jr}$ en $14,4 \mathrm{~kg} \mathrm{P} / \mathrm{ha} / \mathrm{jr}$ voor grondgebonden teelt. Vermenigvuldigd met het totaal areaal substraatteelt en grondgebonden teelt komt dit in 2010 neer op een emissie van 1.309 ton $\mathrm{N}$ en 197 ton $\mathrm{P}$ per jaar voor substraatteelt en een emissie van 225 ton $\mathrm{N}$ en 12 ton P per jaar voor grondgebonden teelt. Voor de substraatteelt gaat 5\% van de emissie naar de bodem, 50\% naar het oppervlaktewater en $45 \%$ naar het riool. Voor de grondgebonden teelten gaat $20 \%$ van de emissies naar de bodem, 60\% naar het oppervlaktewater en 20\% naar het riool (Klein, 2012).

\subsection{Gewasbeschermingsmiddelen en biociden}

In de Atlas Bestrijdingsmiddelen in Oppervlaktewater (www.bestrijdingsmiddelenatlas.nl) zijn de belangrijkste probleemstoffen uit de gewasbescherming in kaart gebracht. Tabel 5.5 geeft voor 2014 de top 10 probleemstoffen, geredeneerd vanuit normoverschrijdingen in Nederland voor drie criteria:

- JG-MKN/MTR = veilige concentratie bij langdurige blootstelling

- MAC-MKN = veilige concentratie bij kortdurende piekblootstelling

- toelatingscriterium CTGB = verwachte concentratie volgens toelatingsdossier.

\section{Tabel 5.5}

Top 10 bestrijdingsmiddelen die de kwaliteitsnorm het meest overschreden in 2014

\begin{tabular}{clll} 
\# & JG-MKN/MTR a) & MAC-MKN b $)$ & Toelatingscriterium (Ctgb ) \\
\hline 1 & terbuthylazin, desethyl- & esfenvaleraat & imidacloprid \\
\hline 2 & ETU & pirimifos-methyl & esfenvaleraat \\
\hline 3 & imidacloprid & captan & carbendazim \\
\hline 4 & benzothiazol & heptachloor-epoxide, cis- & pirimifos-methyl \\
\hline 5 & esfenvaleraat & imidacloprid & abamectine \\
\hline 6 & heptachloor-epoxide, cis- & carbendazim & pirimicarb \\
\hline 7 & azoxystrobin & heptachloor & nicosulfuron \\
\hline 8 & telodrin & linuron & cypermethrin \\
\hline 9 & DDE, 24 & azinfos-methyl & deltamethrin \\
\hline 10 & DDT, 24 & abamectine & spinosad
\end{tabular}

a) JG-MKN de Jaargemiddelde- milieukwaliteitsnormen; b) MAC-MKN de Maximaal Aanvaardbare Concentratie milieukwaliteitsnormen Bron: www.bestrijdingsmiddelenatlas.nl 
Een aantal stoffen uit de top 10 overschrijden de normen gelijktijdig bij verschillende criteria zoals imidacloprid, esfenvaleraat, abamectine, carbendazim en heptachloor.

In de 2e Nota Duurzame Gewasbescherming (Gezonde Groei, Duurzame Oogst) is afgesproken dan het aantal normoverschrijdingen van gewasbeschermingsmiddelen in oppervlaktewater (ten opzichte van 2013) zal worden verminderd met $50 \%$ in 2018 en met $90 \%$ in 2023 . Hiervoor wordt een stofgerichte aanpak gevolgd, waarbij de betrokken toelatingshouders worden opgeroepen om emissiereductie-plannen ter goedkeuring voor te leggen aan het College Toelating Gewasbeschermingsmiddelen en Biociden.

De afzet van chemische gewasbeschermingsmiddelen voor het gebruik in de land- en tuinbouw is in 2014 met ruim 3\% gedaald ten opzichte van 2013. Ten opzichte van 1985 is de afzet ruim gehalveerd (zie Figuur 5.3).

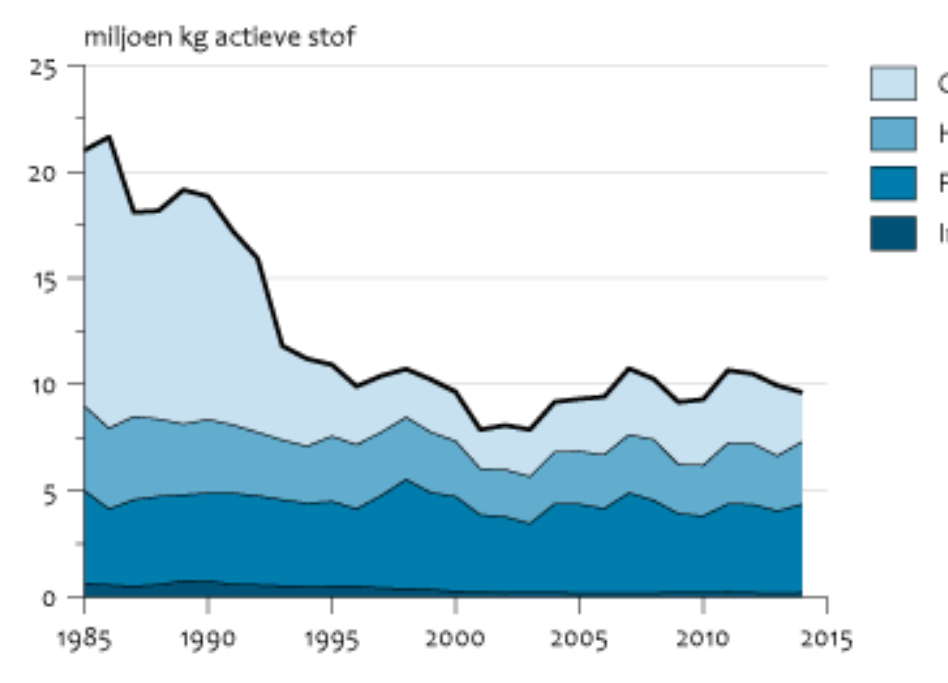

Bron: Nefyto.
Overige middelen

Herbiciden

Fungiciden

Insecticiden / acaraciden

Figuur 5.3 Afzet van gewasbeschermingsmiddelen in land- en tuinbouw Bron: Compendium voor de Leefomgeving

Het totale gebruik van gewasbeschermingsmiddelen in de land- en tuinbouw is sinds 2000 licht gestegen. Tot 2000 was er een daling. In 2012 werd $86 \%$ van het totale gebruik (gemeten over bijna 60 gewassen) toegepast in slechts elf gewassen. Bij sommige gewassen neemt het gebruik per hectare af en bij andere juist toe. Van alle gewasbeschermingsmiddelen werd in 2012 meer dan de helft toegepast bij aardappelen (39\%) en bij lelies (bollen) (12\%). Verder werden de middelen vooral gebruikt bij zaaiuien (7\%), suikerbieten (6\%), tulpen (5\%), snijmais (5\%), wintertarwe (5\%), appels ( $4 \%$ ) en peren (3\%). De resterende $14 \%$ werd bij overige gewassen gebruikt (bron: CBS). 


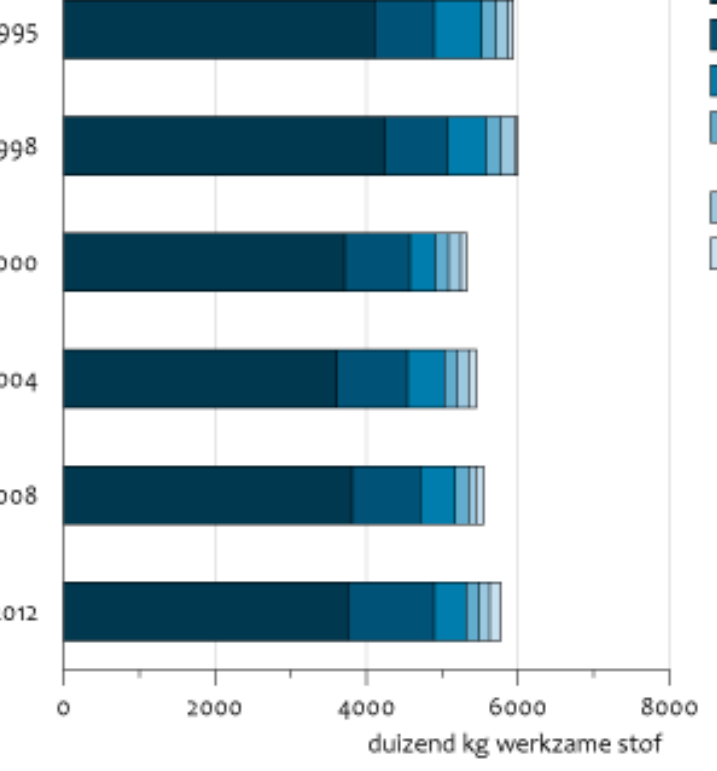

Akkerbouw

Bloembollen en -knollen

Pit- en steenvruchten

Glastuinbouw en champignons

Groenten open grond

Boomkwekerijgewassen

Bron: CBS.

Figuur 5.4 Gebruik van gewasbeschermingsmiddelen per sector Bron: Compendium voor de Leefomgeving

Uit Figuur 5.4 kan worden afgeleid dat ongeveer 3\% van het gebruik van gewasbeschermingsmiddelen in de glastuinbouw zit en $97 \%$ in de akkerbouw en opengrondtuinbouw.

\subsection{Diergeneesmiddelen}

In 2014 bedroeg de omzet in van diergeneesmiddelen in Nederland ongeveer $€ 280 \mathrm{mln}$. (op basis van de lijstprijs), dat is circa $6 \%$ van de totale Europese markt. Iets minder dan de helft daarvan wordt bepaald door het gebruik van antibiotica en antiparasitica bij landbouwhuisdieren. De bedragen zijn een schatting, gebaseerd op verkochte verpakkingen van de leden van de FIDIN. ${ }^{5}$ In Tabel 5.6 is de verdeling van de antibiotica over de verschillende diersoorten in de veehouderij beschreven. Zoals uit deze tabel en Figuur 5.5 blijkt zijn de varkens- en kalversector de grootste gebruikers van antibiotica (in totale hoeveelheid werkzame stof). In deze sectoren en in de pluimveehouderij worden veel antibiotica toegediend via voer of drinkwater, terwijl in de rundveehouderij de meeste antibiotica worden toegediend via injectie of via injectoren in het uier.

\section{Tabel 5.6}

Verdeling antibioticumgebruik in kg over sectoren, totaalgebruik en verkoopcijfers in 2014

\begin{tabular}{lrrrrrrr} 
Diersoort & Varken & Kalveren & Rundvee & Vleeskuikens & Kalkoen & Totaal a) & Verkoopcijfers b) \\
Totaal & 82.380 & 62.733 & 25.629 & 16.220 & 3.092 & 190.055 & 207.012 \\
\hline
\end{tabular}

a) Totaal is het aantal $\mathrm{kg}$ antibioticum zoals gerapporteerd door veehouders en dierartsen aan de SDA; b) Verkoopcijfers is het aantal kg

verkocht aan dierenartsen door fabrikanten en importeurs van diergeneesmiddelen zoals gerapporteerd door FIDIN aan de SDa Bron: SDa

\footnotetext{
5 http://www.fidin.nl/Beleid/Gebruik/Cijfers
} 


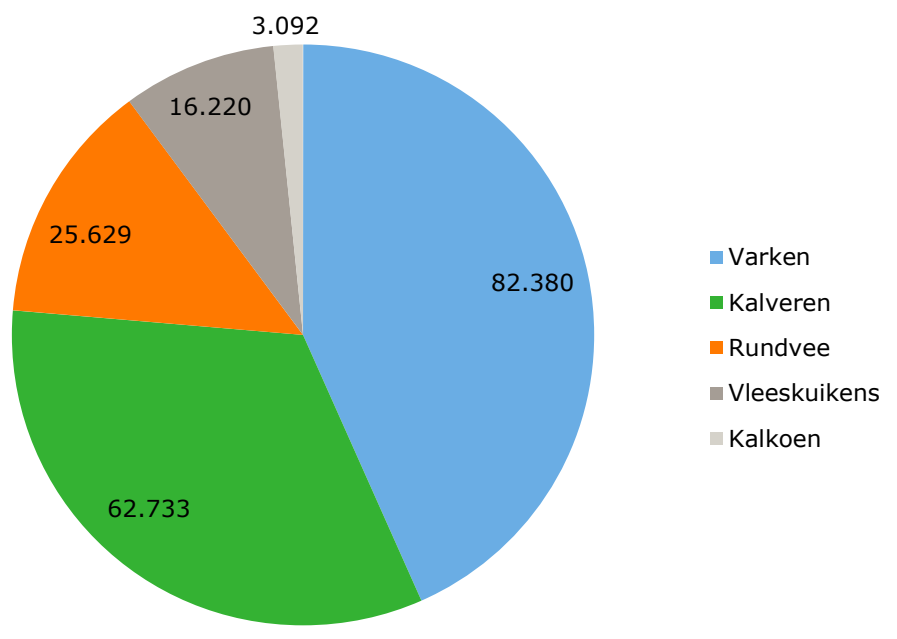

Figuur 5.5 Antibioticumgebruik in de verschillende veehouderijsectoren in 2014 (in $\mathrm{kg}$ )

\section{Trend in antibioticagebruik}

Figuur 5.6 laat de trend van de totale verkopen van veterinaire antibiotica zien, van het therapeutisch gebruik, dus exclusief het gebruik van antimicrobiële groeibevorderaars (AGP). Vanaf het jaar 2006 is het gebruik van antibiotica als groeibevorderaar in de EU verboden.

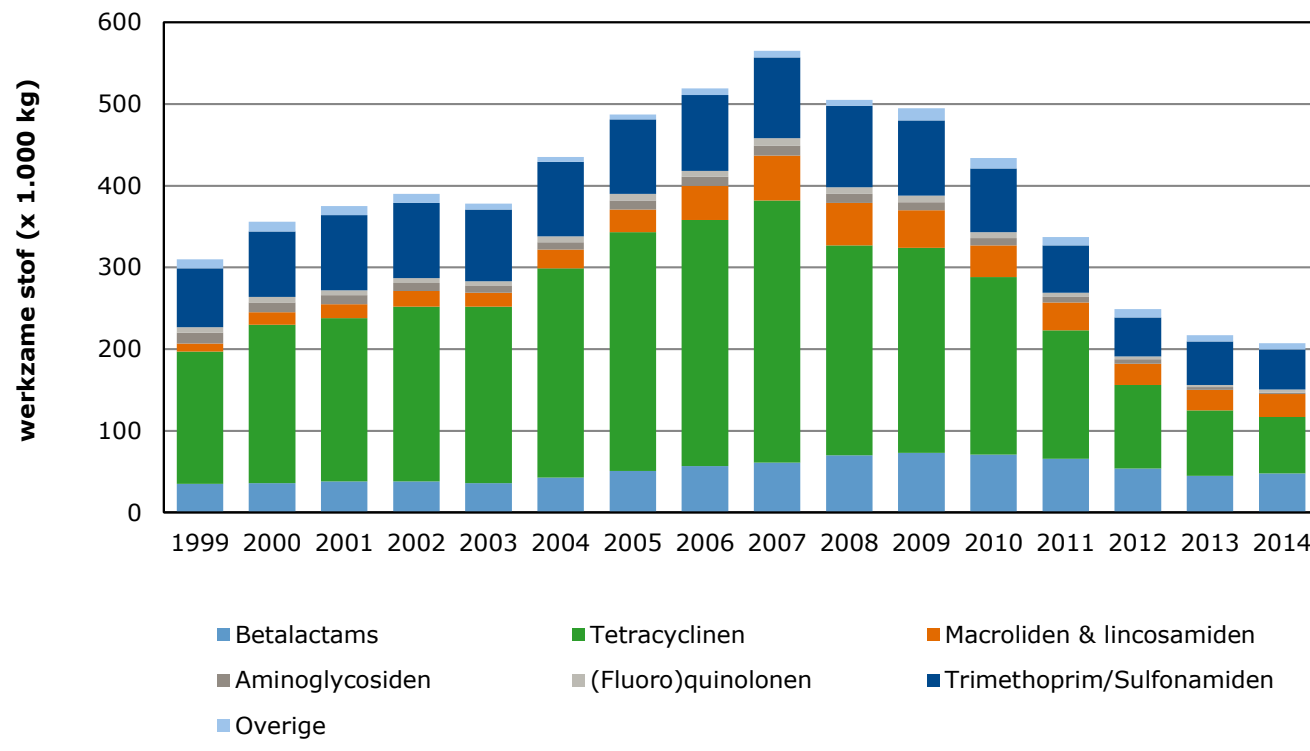

Figuur 5.6 Veterinair antibioticagebruik van 1999-2014; verkopen in $1.000 \mathrm{~kg}$ a)

a) Exclusief het gebruik van groeibevorderaars in de jaren 1999-2005

Bron: Autoriteit Diergeneesmiddelen (SDa)

De verschillende veehouderijsectoren verschillen in de mate waarin het antibioticagebruik in de periode 2009-2014 zich heeft ontwikkeld: van -38\% bij vleeskalveren tot $-58 \%$ bij melkkoeien. In de vleeskalversector werd in de jaren 2007-2009 al een reductie van ongeveer 15\% gerealiseerd. 


\subsection{Zware metalen}

De belasting van de bodem met zware metalen is al geruime tijd een belangrijk aandachtspunt in het milieu- en landbouwbeleid. De accumulatie (ophoping) van zware metalen in de bodem die daarvan het gevolg is kan onder meer gezondheidsproblemen voor het vee opleveren. Door regelgeving die de gehalten van zware metalen in veevoer aan een maximum bindt en door het gebruik van schonere grondstoffen bij de kunstmestproductie is de belasting van de bodem in de loop der jaren sterk afgenomen. Tussen 1980 en 2009 is de jaarlijkse nettobelasting van landbouwgrond met koper met $70 \%$ en met zink met $51 \%$ afgenomen. Bij cadmium is er sprake van een daling van circa $90 \%$. De normen voor de gehalten koper en zink in mengvoeders zijn medio 2000 verscherpt. Hierdoor is de hoeveelheid van deze metalen in dierlijke mest sterk gedaald (Tabel 5.7). ${ }^{6}$

\section{Tabel 5.7}

Zware metalen op landbouwgrond, 1980-2009

\begin{tabular}{|c|c|c|c|c|c|c|c|}
\hline \multicolumn{2}{|l|}{ Onderwerpen/jaar } & 1980 & 1990 & 1995 & 2000 & 2005 & 2009 \\
\hline \multicolumn{8}{|l|}{ Koper (CU) $* 1.000 \mathrm{~kg}$} \\
\hline \multirow[t]{3}{*}{ Brutobelasting (Aanvoer) } & Totaal brutobelasting & 1.360 & 970 & 800 & 780 & 515 & 465 \\
\hline & Kunstmest & 150 & 120 & 50 & 50 & 40 & 25 \\
\hline & Depositie (neerslag) & 80 & 50 & 20 & 20 & 20 & 20 \\
\hline \multirow{4}{*}{$\begin{array}{l}\text { Afvoer zware metalen met } \\
\text { gewassen }\end{array}$} & Totaal afvoer met gewassen & 140 & 130 & 110 & 100 & 95 & 100 \\
\hline & Akkerbouwgewassen & 27,5 & 33,2 & 31,4 & 32,3 & 33,4 & 35,3 \\
\hline & Graslandgewassen & 110,1 & 100 & 76,8 & 65,5 & 61,7 & 65,7 \\
\hline & Tuinbouwgewassen & 0,5 & 0,5 & 0,5 & 0,5 & 0,5 & 0,5 \\
\hline \multirow[t]{5}{*}{ Brutobelasting (Aanvoer) } & Totaal brutobelasting & 2.400 & 2.270 & 2.260 & 2.170 & 1.515 & 1.430 \\
\hline & Dierlijke mest & 1.800 & 1.750 & 2.000 & 1.900 & 1245 & 1.190 \\
\hline & Kunstmest & 150 & 140 & 60 & 60 & 45 & 25 \\
\hline & Depositie (neerslag) & 260 & 180 & 100 & 70 & 65 & 65 \\
\hline & Overige bronnen & 190 & 200 & 100 & 140 & 160 & 150 \\
\hline \multirow{4}{*}{$\begin{array}{l}\text { Afvoer zware metalen met } \\
\text { gewassen }\end{array}$} & Totaal afvoer met gewassen & 700 & 690 & 720 & 570 & 550 & 590 \\
\hline & Akkerbouwgewassen & 215,5 & 253,2 & 248,2 & 223,9 & 228,8 & 251,1 \\
\hline & Graslandgewassen & 475,3 & 428,2 & 469 & 340,8 & 314,1 & 329,4 \\
\hline & Tuinbouwgewassen & 7 & 7 & 7 & 7 & 7 & 7 \\
\hline \multirow{2}{*}{ Brutobelasting (Aanvoer) } & Depositie (neerslag) & 2 & 1 & 1 & 1 & 1 & 1 \\
\hline & Overige bronnen & 1 & 0 & 0 & 0 & 0 & 0 \\
\hline \multirow{4}{*}{$\begin{array}{l}\text { Afvoer zware metalen met } \\
\text { gewassen }\end{array}$} & Totaal afvoer met gewassen & 3 & 3 & 3 & 3 & 3 & 3 \\
\hline & Akkerbouwgewassen & 1,1 & 1,4 & 1 & 1 & 1 & 1 \\
\hline & Graslandgewassen & 2,1 & 1,9 & 1,7 & 1,6 & 1,6 & 1,6 \\
\hline & Tuinbouwgewassen & 0 & 0 & 0 & 0 & 0 & 0 \\
\hline \multicolumn{2}{|c|}{ Nettobelasting (Aanvoer minus Afvoer) } & 12 & 6 & 3 & 3 & 2 & 1 \\
\hline
\end{tabular}

Bron: CBS, 2015

\footnotetext{
6 www.compendiumvoordeleefomgeving.nl/indicatoren/nl009716-Zware-metalen-op-landbouwgrond.html?i=
} 


\section{Bestaande instrumenten}

In dit hoofdstuk wordt per stofcategorie een overzicht op hoofdlijnen gegeven van de bestaande instrumenten die op het ogenblik binnen de landbouw worden ingezet. De belangrijkste instrumenten per categorie worden weergegeven. Dit hoofdstuk beoogt niet uitputtend te zijn en is nadrukkelijk geen ex-post evaluatie van het ingezette beleid. De instrumenten worden beschreven en ook beoordeeld aan de hand van het RESET-model.

\subsection{Bestaande instrumenten per stofcategorie}

\subsubsection{Nutriënten}

Stikstof en fosfor zijn belangrijke voedingsstoffen voor de productie van landbouwproducten in de Nederlandse landbouw. Een optimale benutting ervan is belangrijk vanuit milieuoogpunt omdat de landbouw al jaren te maken heeft met grote mineralenoverschotten. Deze vinden hun oorsprong in het grootschalig gebruik van kunstmest en grotendeels geïmporteerde veevoedergrondstoffen. Jarenlang is de productie van de Nederlandse landbouw sterk gegroeid door voortdurende groei van de veestapel en schaalvergroting met weinig oog voor een efficiënte omgang met voedingsstoffen. Na de introductie van de eerste beleidsmaatregelen om de mestoverschotten terug te dringen (1984) zijn de overschotten van stikstof en fosfor gaan dalen. Dit ging gepaard met een toenemende benutting (tussen 1970 en 2010 is de benutting van fosfor toegenomen van $20 \%$ tot ruim $80 \%$ ). Dit is bereikt door minder kunstmest te gebruiken en door een toename van de afzet van dierlijke mest buiten de landbouw. Een aantal belangrijke instrumenten die daaraan hebben bijgedragen of nog steeds bijdragen zijn:

\section{Superheffing}

De Beschikking Superheffing (1984) leidde tot een sterke daling van het aantal runderen. Ook zijn onder invloed van de Mestwetgeving de mineralengehalten van krachtvoer, vooral de fosforgehalten, gedaald. Verder is in de periode 1986 tot 1990 het gebruik van stikstofkunstmest aanzienlijk afgenomen. Daarna is tot 1999 het stikstofgebruik en daarmee het overschot echter nauwelijks nog gedaald. Dit komt doordat het mestbeleid aanvankelijk vooral gericht was op het terugdringen van het fosfaatgebruik. Desondanks stagneerde ook de daling van het fosfaatoverschot in de periode 1990-1999 enigszins.

\section{MINAS}

MINAS (Mineralenaangiftesysteem) werd ontwikkeld als uitvoering van de Europese Nitraatrichtlijn. Hierdoor richt het mestbeleid zich vanaf 1998 meer op stikstof. Er worden normen gesteld aan het toelaatbare verlies van stikstof en fosfor ten einde onder meer de uitspoeling van nitraat naar het grondwater en oppervlaktewater te beperken en de kwaliteit van het drinkwater veilig te stellen. In 2006 is echter op last van de Europese Commissie het MINAS-beleid weer verlaten. In de plaats daarvan is nieuw mestbeleid geïntroduceerd waarbij niet de verliesnormen van MINAS het uitgangspunt vormen maar gebruiksnormen voor stikstof en fosfor. Na de stagnatie van de afname van de overschotten in de jaren negentig is tot op heden weer sprake van een geleidelijke en continue daling (CBS, 2012). 


\section{Dierrechten}

De beheersing van de landelijke mestproductie van varkens en pluimvee is onderdeel van het mestbeleid. Een bedrijf mag gemiddeld genomen in een kalenderjaar niet meer varkens of kippen houden dan het aantal dierproductierechten. ${ }^{7}$

Rechten worden toegekend op basis van het (gemiddeld) gehouden aantal dieren op een bedrijf en de forfaitaire fosfaatproductie per dier, zoals deze thans is opgenomen in de Meststoffenwet. Een nadeel van een stelsel van dierrechten is dat niet direct gestuurd wordt op het fosfaatproductieplafond. Het stelsel geeft geen prikkel aan individuele ondernemers om de fosfaatefficiëntie te verhogen. Winst die geboekt wordt met het voerspoor vertaalt zich niet naar de mogelijkheid om meer dieren te houden.

\section{Fosfaatrechten in de melkveehouderij}

De superheffing is 1 april 2015 afgeschaft. Vooruitlopend op het wegvallen van de melkquotering, heeft een deel van de melkveehouders sinds december 2013 zijn bedrijf sterk uitgebreid hetgeen geleid heeft tot overschrijden van het fosfaatplafond. In een poging deze overschrijding aan banden te leggen heeft is in mei 2015 een nieuw systeem aangekondigd om de toename van de hoeveelheid fosfaat van melkvee te begrenzen, fosfaatrechten. Voor elk melkveebedrijf zal een maximaal per jaar te produceren hoeveelheid fosfaat worden vastgesteld. Die vastgestelde fosfaatproductie zal in de vorm van fosfaatrechten aan het betreffende bedrijf worden toegekend (EZ, 2015).

De uitvoering van een stelsel van fosfaatrechten is complexer dan de uitvoering van een stelsel van dierrechten. Voor de bedrijfsspecifieke verantwoording ligt het gebruik van de Kringloopwijzer het meest voor de hand. De Kringloopwijzer brengt de mineralenefficiëntie in beeld waardoor op bedrijfsniveau kan worden gestuurd op de benutting van mineralen. Het is van belang dat de werking van de Kringloopwijzer objectief is bepaald en wetschappelijk deugdelijk is. Daarnaast dient het gebruik van de Kringloopwijzer door individuele ondernemers privaat te worden geborgd. De zuivelketen heeft recent aangekondigd de Kringloopwijzer per 1 januari 2016 verplicht te zullen stellen voor alle melkveehouderijbedrijven en zorg te willen dragen voor een geborgde centrale database Kringloopwijzer. Fosfaatrechten geven uitsluitend het recht om fosfaat met melkvee te produceren. Om ontwikkeling van individuele bedrijven mogelijk te maken zal, analoog aan het stelsel van productierechten voor varkens en pluimvee, verhandelbaarheid van fosfaatrechten toegelaten worden.

\section{Mestbeleid $^{8}$}

De dier- en fosfaatrechten maken deel uit van het mestbeleid. Het mestbeleid in Nederland is gebaseerd op de Nitraatrichtlijn. In deze richtlijn zijn afspraken gemaakt over de hoeveelheid nitraat die is toegestaan in het grond- en oppervlaktewater. Om de doelstelling van de Nitraatrichtlijn te halen zijn er maatregelen voor bemesting genomen.

De belangrijkste onderdelen van het mestbeleid zijn:

- Gebruiksnormen voor de hoeveelheden stikstof en fosfaat uit alle meststoffen die toegepast mogen worden bij de teelt van gewassen. Hiermee ontvangt ieder gewas precies de hoeveelheid meststoffen die het nodig heeft.

- De mestverwerkingsplicht. Dit is de verplichting voor landbouwers om een deel van het bedrijfsoverschot te laten verwerken. De overheid wil er zo voor zorgen dat de druk op de gebruiksnormen afneemt.

- Verantwoorde groei melkveehouderij. Met dit stelsel wordt verantwoorde groei van melkveebedrijven mogelijk gemaakt.

- Een stelsel van dierrechten dat grenzen stelt aan het aantal dieren dat voor productie mag worden gehouden.

- Gebruiksvoorschriften voor de manier waarop mest wordt gebruikt en de perioden waarin dit gebeurt. De mest komt op het juiste moment en op de meest efficiënte manier bij gewassen terecht. Hierdoor wordt verlies naar het milieu beperkt.

\footnotetext{
7 www.rvo.nl/onderwerpen/agrarisch-ondernemen/mest-en-grond/mest/dierproductierechten

8 www.rvo.nl/onderwerpen/agrarisch-ondernemen/mest-en-grond/mest
} 
- Regels voor het vervoeren van mest. Zo is altijd bekend waar de mest vandaan komt en waar het naartoe gaat.

- Regels voor het be- en verwerken van meststoffen.

Tabel 6.1 laat zien op welke onderdelen van het RESET-model het bestaand instrumentarium op het gebied van nutriënten gericht is.

Naast de bovengenoemde instrumenten zijn er nog een aantal andere instrumenten die een bijdrage kunnen leveren aan het terugdringen van de emissies van nutriënten:

- Duurzame Zuivelketen - Dit gezamenlijk initiatief van NZO, de koepel van zuivelverwerkers en LTO Nederland heeft als doel de kwalitatief hoogwaardige Nederlandse zuivel ook steeds duurzamer geproduceerd te maken. In eerste instantie zijn daarvoor duurzaamheidsdoelen tot 2020 geformuleerd. Binnen de Duurzame Zuivelketen zijn vier hoofdthema's benoemd. Behoud van milieu en biodiversiteit is daar één van. Binnen dit thema zijn doelen benoemd waaronder het verminderen van het fosfaatvolume in mest het verbeteren van de stikstof efficiëntie. De 13 deelnemende zuivelondernemingen die zich bij de Duurzame Zuivelketen hebben aangesloten, verwerken $98 \%$ van de in Nederland geproduceerde melk.

- Maatlat Duurzame Veehouderij (MDV) (2007-2015) - investeringsregeling voor nieuwbouw van duurzame stallen. Hoe duurzamer het stalontwerp en de inrichting, hoe meer punten op de maatlat gescoord worden. Dat betekent dat niet alle stallen die onder de MDV gebouwd worden per definitie bijdragen aan emissie- en energiedoelen;

- Kringloopwijzer - Deze opvolger van MINAS brengt voor een specifiek bedrijf eenvoudig de mineralenkringlopen in beeld. Uit de kringlopen volgen dan weer kringloopscores als excreties van stikstof en fosfaat, overschotten van stikstof en fosfaat, mineralenbenuttingen en ammoniakemissie.

- IDSH - subsidieregeling voor investeringen in duurzame stallen.

- VAMIL/MIA - Deze regelingen stimuleren ondernemers om te investeren in milieuvriendelijke technieken. Met de MIA is een investeringsaftrek mogelijk die kan oplopen tot $36 \%$ van het investeringsbedrag. Dat komt bovenop de gebruikelijke investeringsaftrek van een ondernemer. De Vamil biedt de mogelijkheid om $75 \%$ van de investeringskosten op een door de ondernemer zelf te bepalen tijdstip af te schrijven. De MIA stimuleert verduurzaming.

- Garantstelling plus - Deze regeling van het ministerie van EZ (uitvoering door RVO) maakt deel uit van de Garantstelling Landbouw (GL) en is bedoeld voor landbouwondernemers óf startende landbouwondernemers van 39 jaar of jonger. Het doel van de regeling is (jonge) agrariërs uit de glastuinbouw of veehouderij te stimuleren om zich te ontwikkelen, te investeren en duurzaam en efficiënt te produceren. Garantstelling Plus geeft een garantstelling op een aanvullende lening voor bijvoorbeeld de bouw van een Groen Label-kas of stal.

- Activiteitenbes/uit milieubeheer - Hierin staan onder andere eisen voor veehouderijen voor het houden van landbouwhuisdieren in dierenverblijven en het opslaan van vaste mest of drijfmest.

- Akkerranden/ teeltvrije zones - Deze kunnen worden toegepast om emissies van nutriënten (en gewasbeschermingsmiddelen) naar het oppervlaktewater te beperken. 
Tabel 6.1

Nutriënten: duiding bestaande instrumenten aan de hand van het RESET-model a)

\begin{tabular}{|c|c|c|c|c|c|c|}
\hline Instrument & Doel & $\mathbf{R}$ & E & s & E & $\mathbf{T}$ \\
\hline Superheffing/melkquotering & Beperken melkveestapel & $x$ & & & $x$ & \\
\hline MINAS & Reguleren mineralenstromen & $x$ & $x$ & & & $x$ \\
\hline Fosfaatrechten & Inperken van fosfaatoverschot & $x$ & & & & \\
\hline Mestbeleid & Verlagen mineralenoverschotten & $x$ & & & & \\
\hline Maatlat Duurzame Veehouderij & Investering in duurzame stallen & $x$ & & $x$ & $x$ & \\
\hline Kringloopwijzer & Opvolger MINAS melkveehouderij & & & & & $x$ \\
\hline IDSH & Investering in duurzame stallen & & & & $x$ & \\
\hline VAMIL/ MIA & Milieuvriendelijke technieken & & & & $x$ & \\
\hline Garantstelling plus & Duurzaam produceren & & & & $x$ & \\
\hline
\end{tabular}

a) Regels, Educatie, Sociale druk, Economische incentives en Tools

\section{Toelichting nutriënten}

Om emissies van nutriënten naar het grondwater terug te dringen worden naast economische incentives vooral wet- en regelgeving toegepast. Niet veel instrumenten lijken bij te dragen aan educatie, sociale druk en tools. Educatie is belangrijk om bewustwording bij ondernemers te vergroten. Sociale druk kan een goed hulpmiddel zijn omdat mensen zich vaak meer door anderen laten beïnvloeden dan ze zelf denken (Nolan et al., 2008). Tools zijn belangrijk omdat ondernemers handelingsperspectief (concrete maatregelen) nodig hebben om bij te kunnen dragen aan bepaalde doelen (De Lauwere et al., 2015). Of de bovengenoemde instrumenten effectief genoeg zijn, valt te bezien. Uit de evaluatie van de meststoffenwet 2012 blijkt dat in de periode 2006-2010 de helft van de meetlocaties voldoet aan de waterkwaliteitsnormen voor stikstof en fosfor. Voor stikstof in grondwater in Zuid Nederland is dit minder dan een kwart (PBL, 2012). Het Planbureau voor de leefomgeving schijft hierover het volgende:

'Nederland voert al 25 jaar mestbeleid met als doel om de milieubelasting door het gebruik van de voedingsstoffen stikstof en fosfor in meststoffen terug te dringen. Daarbij gaat het vooral om de milieubelasting te verminderen en daarmee de kwaliteit van het grond- en oppervlaktewater te verbeteren. Door het huidige mestbeleid verbetert de grondwaterkwaliteit na 2010 mogelijk nog licht, voor de oppervlaktewaterkwaliteit zal dit nauwelijks het geval zijn. Wil Nederland overal de doelen voor oppervlakte- en grondwater realiseren, dan is het nodig het mestbeleid verder aan te scherpen.' (PBL, 2012)

In 2016 wordt de (aangescherpte) mestwetgeving opnieuw geëvalueerd.

\section{Kader 6.1}

\section{Succesverhaal: MINAS}

RIVM (2002) noemde de MINAS-systematiek conceptueel een goed systeem, vanuit milieu- en landbouwkundig oogpunt. De verliezen vanuit het landbouwsysteem naar het milieu worden zichtbaar gemaakt. MINAS gaf ondernemers een prikkel om de mineralenoverschotten te verlagen. Bovendien bood MINAS de ondernemers een doel en liet het de keus van de te nemen maatregelen aan de ondernemer zelf over. 'Op basis van eerste indicaties blijkt het Mineralenaangiftesysteem (MINAS) een goed instrument te zijn om stikstof- en fosfaatverliezen in de landbouw te verlagen.'

Van de Ham et al. (2007) concluderen dat MINAS weinig of geen stimulansen heeft gegeven tot een efficiënter mineralengebruik, omdat de mestafvoer per ton en niet naar gehalten wordt betaald. Wel was MINAS één van de sturende omgevingsfactoren die bedrijven heeft gemotiveerd om de macht der gewoonte te doorbreken, bijvoorbeeld door een niet plaatsbaar ruwvoeroverschot te verminderen. 'Dan gaat men zoeken naar mogelijkheden. [...] Bij onvoldoende scherpe normen valt die sturing grotendeels weg.' 


\subsubsection{Gewasbeschermingsmiddelen en biociden}

In de keten van gewasbeschermingsmiddelen is een aantal spelers te onderscheiden:

Middelenfabrikanten doen toelatingsaanvragen voor gewasbeschermings- middelen bij de daarvoor aangewezen Europese en nationale autoriteiten. Het aantal toegelaten middelen is de afgelopen 20 jaar sterk beperkt door harmonisatie en aanscherping van de toelatingseisen. De kosten voor opstelling en beoordeling van toelatingsdossiers worden verhaald op de fabrikanten. Voor kleine teelten $(<1.000$ ha) leidde het verhalen van de kosten tot een verdere beperking van het aantal toelatingen. Bij kleine arealen zijn de toelatingskosten volgens de fabrikanten niet meer terug te verdienen, via de verkoop van middelen. In een aantal gevallen zijn de toelatingskosten gedeeld via het fonds kleine toepassingen.

Via een gedragscode (product stewardship) dragen de fabrikanten bij aan een zo verantwoord mogelijke opslag, transport, aanprijzing en aan een veilig en verantwoord gebruik van gewasbeschermingsmiddelen. Via het project TOPPS Nederland (voorafgegaan door projecten als Schone Bronnen en WaterABC) proberen de fabrikanten de emissie van gewasbeschermingsmiddelen naar het oppervlaktewater te beperken. Via deze projecten waren eind 2014 zo'n 9.000 telers bereikt. Dit aantal breidt zich nog steeds uit.

Toelatingshouders (fabrikanten) van wie middelen via bepaalde gewassen leiden tot normoverschrijdingen in oppervlaktewater, worden daar sinds 2014 op aangesproken. Zij worden opgeroepen om voor zulke middelen een emissiereductieplan (ERP) ter goedkeuring voor te leggen. Als het ERP niet leidt tot de gewenste vermindering van het aantal normoverschrijdingen in oppervlaktewater, dan kan de toelating uiteindelijk worden ingetrokken.

Een nieuwe trend is vergroening van de gewasbescherming. Daarbij wordt met name door de fabrikanten van biologische middelen aangedrongen op een vereenvoudigde procedure voor de toelating van laag-risico stoffen.

Toeleveranciers zorgen voor de verkoop en distributie van gewasbeschermingsmiddelen naar boeren en tuinders. Voor boeren en tuinders zijn zij de meest geraadpleegde adviseurs voor de keuze en toepassing van de geleverde middelen. De advieskosten worden meestal verwerkt in de verkoopprijzen van de middelen (gebrekkige transparantie). De verkopers/adviseurs krijgen vaak provisie voor de verkochte hoeveelheden (perverse prikkel).

De toeleveranciers spelen een sleutelrol in de implementatie van initiatieven van de middelenfabrikanten, zoals product stewardship, beperking erfemissie (WaterABC) en beperking emissies (TOPPS Nederland).

De trend naar vergroening van de gewasbescherming komt bij de toeleveranciers in de glastuinbouw tot uiting in het aanbieden van middelen die planten versterken en op die manier de uitbraken van ziekten en plagen beperken.

Akkerbouwers en opengrondtuinders passen gewasbeschermingsmiddelen toe op hun percelen. Het aantal toepassingen verschilt sterk tussen gewassen. Per gewas is het aantal toepassingen afhankelijk van het optreden van ziekten, plagen en onkruiden onder invloed van factoren als grondsoort, klimaat, vruchtwisseling, rassenkeuze en ondernemerstype. In de jaren 1990-2000 is het verbruik bijna gehalveerd, met name door regelgeving rond grondontsmetting. Door de invoering van driftbeperkende maatregelen (Lozingenbesluit tot 2014 daarna overgegaan in Activiteitenbesluit) is de emissie naar oppervlaktewater in de jaren 2000-2010 met circa 70\% verminderd. In combinatie met de substitutie van meest vervuilende door minder vervuilende stoffen, is de milieubelasting naar het oppervlaktewater in die jaren (ten opzichte van 1998) met $85 \%$ verminderd.

Deze reducties in middelengebruik en milieubelasting zijn mede mogelijk gemaakt door de ontwikkeling van resistente rassen en detectiemethoden (aardappelmoeheid) en door onderzoek/kennis-programma's rond geïntegreerde teelt zoals Geïntegreerde Akkerbouw, Masterplan Phytophthora en Telen met Toekomst. De telers konden gebruik maken van Milieumeetlat CLM, FAB- 
projecten van LTO, MIA/VAMIL-regelingen en nieuwe opties voor precisietoediening (GIS/GPS). De gebruikers zijn verplicht hun vakbekwaamheid op peil te houden via spuitlicenties.

Glastuinders passen gewasbeschermingsmiddelen toe in hun kassen. Het aantal toepassingen verschilt sterk tussen gewassen. Per gewas is het aantal toepassingen afhankelijk van het optreden van ziekten en plagen onder invloed van factoren als kasklimaat, rassenkeuze en ondernemerstype. In de jaren 1990-2000 is het verbruik van chemische middelen in de glasgroenteteelt afgenomen door de overgang op biologische bestrijding. Door de invoering van emissiebeperkende maatregelen is de emissie naar oppervlaktewater in de jaren 2000-2010 met circa 60\% verminderd. In combinatie met de substitutie van meest vervuilende door minder vervuilende stoffen, is de milieubelasting naar het oppervlaktewater in die jaren (ten opzichte van 1998) met $60 \%$ verminderd. De meest recente situatie is dat de glastuinbouwbedrijven per 1 januari 2018 verplicht hun afvalwater moeten gaan zuiveren waarbij tenminste $95 \%$ van de gewasbeschermingsmiddelen verwijderd moeten worden. Collectieve zuiveringen kunnen onder strikte voorwaarden tot maximaal 1 januari 2021 uitstel krijgen. Op dit moment hoeft er nog niet worden gezuiverd, op een enkel middel na. Dit is de situatie voor gewasbeschermingsmiddelen. Voor nutriënten geldt dat er emissienormen voor de lozing van stikstof in de wetgeving zijn opgenomen die per drie jaar afnemen totdat in 2027 nagenoeg een nullozing wordt gerealiseerd. Omdat stikstof en fosfor in vaste verhoudingen in het water zitten dat aan de gewassen wordt toegediend en in het afvalwater, zullen ook de emissies van fosfaat afnemen.

De afnemende handel en industrie eisen, met name bij groenten en sinds kort ook bij siergewassen, dat de producenten zich houden aan de wettelijke gebruiksvoorschriften van gewasbeschermingsmiddelen. Zij controleren de geleverde groenten op de maximale residulimieten (MRL's) van de gebruikte middelen. Deze controles (onder de noemer van Global GAP) zijn ontstaan na publieke debatten, onder aanvoering van milieuorganisaties, in de jaren 1995-2005. Bij siergewassen beginnen afnemers systemen te ontwikkelen om de geleverde producten te controleren op residuen van niettoegelaten middelen. Campagnes van milieuorganisaties rond bijensterfte hebben de ontwikkeling van deze systemen in een stroomversnelling gebracht.

De supermarkten eisen van hun toeleveranciers dat de geleverde producten, met name groenten en fruit, voldoen aan de MRL's van de gebruikte gewasbeschermingsmiddelen. Als vorm van voorzorg stellen zij soms bovenwettelijke eisen, zoals maxima aan het aantal stoffen dat mag worden gebruikt en maxima voor de som van de residuniveaus van gebruikte stoffen. Via deze (bovenwettelijke) eisen, duwen de supermarkten de producenten van groenten en fruit in de richting van geïntegreerde gewasbescherming. Bij sierproducten eisen de grootwinkelbedrijven van hun toeleveranciers naleving van de wettelijke gebruiksvoorschriften van de gewasbeschermingsmiddelen. Daarvoor worden systemen ontwikkeld om de geleverde producten te controleren op residuen van niet-toegelaten middelen.

Gebruikers van gewasbeschermingsmiddelen kunnen aangebroken verpakkingen en moeilijk schoon te spoelen verpakkingen gratis inleveren als Klein Gevaarlijk Afval bij gemeentelijke KCA-depots. De gemeentes kunnen de kosten voor afvoer en vernietiging declareren bij de Stichting Opruiming Restanten Landbouwbestrijdingsmiddelen (STORL). De financiële middelen van de STORL worden opgebracht door de toelatingshouders.

Voor de reiniging van verpakkingen is een verordening vastgesteld, die gebruikers van gewasbeschermingsmiddelen verplicht om verpakkingen direct na het leegmaken ervan te spoelen met voorgeschreven apparatuur. Om die reden is op de meeste spuitmachines een spoelinrichting gemonteerd.

Tabel 6.2 geeft een overzicht van de bestaande instrumenten op het gebied van gewasbeschermingsmiddelen en biociden, in de akkerbouw en opengrondtuinbouw, aan de hand van het RESET-model. Tabel 6.3 geeft een vergelijkbaar overzicht, voor de glastuinbouw. 
Tabel 6.2

Overzicht en analyse van bestaande instrumenten in de gewasbeschermingsketen Open Teelten (akkerbouw + opengrondtuinbouw)

\begin{tabular}{|c|c|c|c|c|c|c|}
\hline \multirow[t]{2}{*}{ Schakel/instrument } & \multirow[b]{2}{*}{ Doel } & \multicolumn{5}{|c|}{ RESET-element a) } \\
\hline & & $\mathbf{R}$ & E & $\mathbf{S}$ & E & $\mathbf{T}$ \\
\hline \multicolumn{7}{|l|}{ Middelenfabrikanten } \\
\hline Fonds Kleine toepassingen & Middelen kleine gewassen & & & & $x$ & $x$ \\
\hline Product Stewardship & Verantwoord gebruik & $x$ & $x$ & & & \\
\hline TOPPS-Nederland & Beperking emissie & & $x$ & $x$ & & \\
\hline Emissie-Reductie-Plan & Normoverschrijdingen & $x$ & & & $x$ & \\
\hline \multicolumn{7}{|l|}{ Middelenhandel } \\
\hline \multicolumn{7}{|l|}{ Teeltbedrijven } \\
\hline Regulering grondontsmetting & Reductie middelengebruik & $x$ & & & & \\
\hline Activiteitenbesluit & Beperking emissie/drift & $x$ & & & & \\
\hline Resistente rassen & Geen grondontsmetting & & & & & $x$ \\
\hline Detectiemethoden & Bepalen aaltjesdichtheid & & & & & $x$ \\
\hline Geïntegreerde Akkerbouw & Geïntegreerde teelt & & $x$ & & & $x$ \\
\hline Milieumeetlat CLM & Milieubelastingpunten & & $x$ & & & \\
\hline Masterplan Phytophthora & Beheersing Phytophthora & & $x$ & $x$ & & $x$ \\
\hline Spuitlicentie & Vakbekwaamheid GWB & $x$ & $x$ & & & \\
\hline \multicolumn{7}{|l|}{ Afvoer restanten/fust } \\
\hline STORL-afspraken & Opruimen restanten & & & $x$ & $x$ & \\
\hline Spoelinrichting veldspuit & Schoonspoelen fust & $x$ & & & & \\
\hline \multicolumn{7}{|l|}{ Verwerkers/handelshuizen } \\
\hline Global GAP & Naleving voorschriften & $x$ & & & $x$ & \\
\hline \multicolumn{7}{|l|}{ Supermarkten/retailers } \\
\hline Residu-eisen & Behoud van reputatie & $x$ & & & $x$ & \\
\hline
\end{tabular}

a) Regels, Educatie, Sociale druk, Economische incentives en Tools 
Tabel 6.3

Overzicht en analyse van bestaande instrumenten in de gewasbeschermingsketen Open Teelten (glastuinbouw)

\begin{tabular}{|c|c|c|c|c|c|c|}
\hline \multirow[t]{2}{*}{ Schakel/instrument } & \multirow[b]{2}{*}{ Doel } & \multicolumn{5}{|c|}{ RESET-element a) } \\
\hline & & $\mathbf{R}$ & E & s & E & $\mathbf{T}$ \\
\hline \multicolumn{7}{|l|}{ Middelenfabrikanten } \\
\hline Fonds Kleine toepassingen & Middelen kleine gewassen & & & & $x$ & $x$ \\
\hline Product Stewardship & Verantwoord gebruik & $x$ & $x$ & & & \\
\hline Emissie-Reductie-Plan & Normoverschrijdingen & $x$ & & & $x$ & \\
\hline Toelating laag risico stoffen & Vergroening gewasbesch & $x$ & & & $x$ & \\
\hline \multicolumn{7}{|l|}{ Middelenhandel } \\
\hline Activiteitenbesluit & Beperking emissie & $x$ & & & & \\
\hline Spuitlicentie & Vakbekwaamheid GWB & $x$ & $x$ & & & \\
\hline Glastuinbouw Waterproof & Beperking emissie & & & & & $x$ \\
\hline Telen met Toekomst & Best Practices & & $x$ & & & $x$ \\
\hline Plantversterkers & Plantweerbaarheid & & & & & $x$ \\
\hline \multicolumn{7}{|l|}{ Afvoer restanten/fust } \\
\hline STORL-afspraken & Opruimen restanten & & & $x$ & $x$ & \\
\hline Spoelinrichting veldspuit & Schoonspoelen fust & $x$ & & & & \\
\hline \multicolumn{7}{|l|}{ Supermarkten/retailers } \\
\hline Residu-eisen & Behoud van reputatie & $x$ & & & $x$ & \\
\hline
\end{tabular}

a) Regels, Educatie, Sociale druk, Economische incentives en Tools

\section{Kader 6.2}

\section{Succesverhaal: Emissiebeperking gewasbescherming open teelten}

Rond het jaar 2000 werd het Lozingenbesluit Open Teelten en Veehouderij ingevoerd. In dit besluit werden verplichtingen opgenomen over de toepassing van teeltvrije zones, driftarme spuitdoppen en kantdoppen. In de onderhandelingen met het bedrijfsleven werd afgesproken, dat bij een goede naleving van deze verplichtingen een breed middelenpakket beschikbaar zou blijven. Bij een slechte naleving zou een aantal middelen zijn toelating kunnen verliezen. Bij de tussentijdse evaluatie van de 1e Nota Duurzame Gewasbescherming in 2005 bleek de taakstelling (75\%) voor vermindering van de milieubelasting naar het oppervlaktewater ruimschoots ( $86 \%)$ gehaald te zijn. Het lozingenbesluit is in 2014 overgegaan in het Activiteitenbesluit.

\section{Kader 6.3}

\section{Minder succesvol verhaal: Certificatieschema gewasbescherming}

Bij de opstelling van het gewasbeschermingsbeleid voor de jaren 2000-2010 werden certificatieschema's voor milieubewuste teelt opgesteld. Volgens de certificatieschema's moesten de telers het middelengebruik en de daarmee verbonden milieubelasting per gewas nauwkeurig gaan bijhouden. Het plan was om de certificatie een wettelijke basis te geven. De verwachting was dat afnemers de certificatieschema's in dank zou aanvaarden. De landbouworganisaties haalden het idee onderuit vanwege de administratieve lastendruk. De afnemers bleken niet bereid om meerprijzen te betalen voor producten die voldoen aan wettelijk vastgelegde milieueisen. 


\subsubsection{Diergeneesmiddelen}

Vanaf 2008 is het Nederlandse beleid ten aanzien van reductie en verantwoord gebruik van antibiotica in de veehouderij opgezet als een publiek-private samenwerking met stakeholders uit de grote veehouderijsectoren en de Koninklijke Nederlandse Maatschappij van Diergeneeskunde, die verantwoordelijkheid moesten nemen voor effectieve maatregelen, met begeleiding en ondersteuning vanuit de nationale overheid. Belangrijke elementen in de aanpak waren:

- Monitoring van de totale verkopen van veterinaire antibiotica (sinds 1999).

- Monitoring van het antibioticagebruik per diersoort (sinds 2004).

- Duidelijke reductiedoelstellingen door de overheid vanaf 2009: -20\% in 2011 en -50\% in 2013 en $70 \%$ in 2015 voor de veehouderij als geheel, in relatie tot het antibioticagebruik in 2009.

- Transparantie en benchmarking van antibioticagebruik per bedrijf en per dierenarts, middels centrale registratie (sinds 2011).

- Verbeterd diergezondheidsmanagement, duidelijke verdeling van verantwoordelijkheden daarin en in het voorschrijven en leveren van antibiotica door:

- verplichte bedrijfsgezondheidsplannen

- één gecontracteerde dierenarts per bedrijf

- verplichte periodieke bedrijfsbezoeken door een dierenarts.

Het antibioticabeleid in de Nederlandse veehouderij is succesvol. Al in 2012 werd de doelstelling van een $50 \%$ reductie gerealiseerd. In 2014 is het veterinair antibioticagebruik gedaald met meer dan $58 \%$, van 495 ton actieve stof in 2009 naar 207 ton in 2014. Deze forse daling is niet het gevolg van een verschuiving naar meer potente middelen, maar van een echte vermindering van het gebruik. Bovendien worden er sinds 2013 in de grote veehouderijsectoren vrijwel geen antibiotica meer gebruikt die van cruciaal belang zijn voor de humane gezondheidszorg. De vermindering van het antibioticagebruik heeft bij de meeste diersoorten geleid tot minder antibioticaresistentie.

De sterke vermindering van het antibioticagebruik lijkt niet ten koste te zijn gegaan van de resultaten. In de jaren 2009-2014 is de veehouderijsector niet gekrompen. Bovendien lijken de gemiddelde technische en economische resultaten niet te zijn verslechterd. Dat betekent dat een vergaande reductie van het veterinair antibioticagebruik in de jaren 2009-2014 mogelijk was, zonder meetbaar nadelige gevolgen voor de technische en economische bedrijfsresultaten. Onzorgvuldig antibioticagebruik is de afgelopen jaren stevig aangepakt. Individuele bedrijven die goede redenen hadden om antibiotica te gebruiken en er helaas niet in slaagden om het gebruik te verlagen zijn tot op heden niet geconfronteerd met sancties.

Een aantal zaken is wettelijk geregeld. Dierenartsen mogen alleen antibiotica voorschrijven als ze een infectie hebben vastgesteld die daarmee behandeld kan worden. De diagnose moet gebaseerd zijn op een klinische inspectie van de dieren. Vervolgens moet de volledige antibioticakuur door de dierenarts worden voorgeschreven/toegediend. Antibiotica mogen niet op het veehouderijbedrijf worden opgeslagen. De zogeheten UDD-regeling is in werking getreden in 2014 en houdt met name in dat alleen een dierenarts antibiotica mag voorschrijven/toedienen. Ook is hierbij geregeld dat:

- veehouders die bij de slachterij dieren aanleveren met teveel antibioticaresiduen niet alleen een hoge boete krijgen, de dieren worden ook afgekeurd voor consumptie, de producten worden vernietigd en de veehouder ontvangt geen opbrengsten en draait op voor de kosten van slacht en afvoer/destructie van de producten. In de zuivel kan de veehouder bovendien aansprakelijk gesteld worden voor vervolgschade indien er sprake is van kruiscontaminatie van producten

- dierenwinkels geen antibiotica mogen verkopen

- antibiotica die voor de mens van cruciaal belang zijn alleen in noodgevallen aan zieke dieren mogen worden toegediend

- grondstoffen voor antibiotica niet zonder vergunning mogen worden opgeslagen of verkocht.

Zie Tabel 6.4 voor een overzicht van de bestaande instrumenten op het gebied van diergeneesmiddelen, aan de hand van het RESET-model. 
Tabel 6.4

Diergeneesmiddelen: duiding bestaande instrumenten aan de hand van RESET-model a)

\begin{tabular}{|c|c|c|c|c|c|}
\hline Instrument & Doel & $\mathbf{R}$ & E & s & E 1 \\
\hline Monitoring totale verkopen antibiotica & Bewustwording (algemeen) & & & $x$ & \\
\hline $\begin{array}{l}\text { Monitoring antibioticagebruik per diersoort } \\
\text { (steekproef); inclusief introductie van meeteenheid } \\
\text { dierdagdosering }\end{array}$ & $\begin{array}{l}\text { Bewustwording (algemeen); mogelijkheden creëren } \\
\text { voor voorlopers om te benchmarken }\end{array}$ & & $x$ & $\mathrm{x}$ & $x$ \\
\hline Formuleren reductiedoelstellingen & Creëren van sense of urgency & & & $x$ & \\
\hline UDD-regeling & $\begin{array}{l}\text { Zorgvuldigheid bij voorschrijven en toedienen van } \\
\text { diergeneesmiddelen }\end{array}$ & $x$ & & & \\
\hline Verbetering diergezondheidsmanagement & & $x$ & $x$ & $x$ & $x$ \\
\hline
\end{tabular}

a) Regels, Educatie, Sociale druk, Economische incentives en Tools

\section{Toelichting Diergeneesmiddelen}

In het diergeneesmiddelenbeleid, en met name het antibioticabeleid, is niet of nauwelijks gebruik gemaakt van financiële prikkels om de emissies terug te dringen. Desondanks is het antibioticabeleid zeer succesvol te noemen. Dit heeft vooral te maken van de jarenlange monitoring die gezorgd heeft voor een toenemende druk om te veranderen, het formuleren van duidelijke doelstellingen en de benchmarking op individuele bedrijven.

In Denemarken heeft men wel duidelijk financiële prikkels aangebracht middels het 'Yellow Card'systeem. Dit heeft kort na de invoering een sterk effect gehad, maar na enige tijd ontstond de indruk dat bedrijven zich naar het toegestane maximum toe gingen bewegen.

\section{Kader 6.4}

\section{Succesverhaal diergeneesmiddelen: Formuleren van duidelijke reductiedoelstellingen} Voor een succesvolle verandering zijn naast een duidelijke 'sense of urgency' ook heldere, liefst gemeenschappelijke doelstellingen nodig. Toen de Nederlandse overheid in 2009 concrete percentages noemde als doelstellingen voor vermindering van het antibioticagebruik, leverde dat naast veel discussie ook veel actie op. Veehouders en dierenartsen zijn vanaf dat moment echt in beweging gekomen om te proberen zoveel mogelijk van de vereiste reductie te realiseren. Hierbij speelde ook een rol de expliciete dreiging voor dierenartsen om het recht kwijt te raken om zelf diergeneesmiddelen te mogen verkopen.

Het succes van de reductiedoelstellingen is mede te danken aan het hiervoor gelegde fundament, in de vorm van een stevige monitoring (verkoopcijfers en gebruikscijfers per sector) en het in 2008 gesloten convenant tussen betrokken publieke en private partijen.

\section{Kader 6.5}

\section{Minder succesvol verhaal diergeneesmiddelen: Bedrijfsgezondheidsplannen}

Er zijn zowel bedrijfsbehandelplannen als bedrijfsgezondheidsplannen geïntroduceerd. In het bedrijfsbehandelplan wordt beschreven wat de standaardbehandeling is bij alle op het bedrijf voorkomende aandoeningen. Op zichzelf is dat nuttig, maar in de praktijk is dit lijstje op de meeste bedrijven hetzelfde en voegt het weinig toe aan de al bestaande praktijk van de dierenarts. Het bedrijfsgezondheidsplan gaat veel verder, en behelst naast een analyse van de diergezondheidsstatus van het bedrijf ook doelen en verbetermaatregelen voor de korte en langere termijn. De indruk bestaat dat deze plannen in de praktijk nog weinig gebruikt worden, omdat er onvoldoende sturing is op het resultaat/effect van de plannen. 


\subsubsection{Zware metalen}

\section{Beleid}

Het beleid is erop gericht om op langere termijn voor alle stoffen de achtergrondwaarde niet te overschrijden.

Voor zware metalen zijn voor landbouwgronden waarden vastgesteld voor maximaal toelaatbare risico (MTR) en verwaarloosbaar risico (VR) ofwel streefwaarde. De streefwaarden liggen zeer veel lager (ca. 20-100) dan de toelaatbare risicowaarden). Het beleid is er op gericht om op lange termijn voor alle zware metalen in de bodem van het landelijk gebied de streefwaarde niet te overschrijden (bron: Compendium voor de Leefomgeving).

Er zijn regionale overzichten van Nederland in welke mate de metalen arseen, nikkel chroom, kwik, lood, koper, cadmium en zink regionaal het meest voorkomen in de bodem (middels analyse van grondmonsters).

Overschrijdingen van de streefwaarde komen voor in Zuidoost-Nederland voor cadmium en zink als gevolg van industriële activiteiten in het verleden in die regio. In het westelijk veenweidegebied komen overschrijdingen voor van de streefwaarde voor van cadmium, zink, kwik, nikkel, koper en lood, vooral als gevolg van de aanwezigheid van zogenaamde 'toemaakdekken' (oude stadscompost met hoge zware metaalgehalten).

\section{Beleid en maatregelen}

De toevoer van zware metalen naar de bodem vanuit de landbouw wordt veroorzaakt door het gebruik van kunstmest en dierlijke mest afkomstig van veehouderijbedrijven. Zware metalen zijn een bestanddeel van diervoeding en komen zo in de dierlijke mest terecht.

De maximale hoeveelheden zware metalen die in de normale kunstmest mogen zitten (meestal mengvormen van stikstof, fosfaat en kalium) zijn vastgesteld in Europese wetgeving (EU verordening 2003/2003 van het Europese Parlement en de Raad). Er zijn voorschriften voor borium, kobalt, koper, ijzer, mangaan, molybdeen en zink.

Voor zware metalen in dierlijke mest - in vaste of vloeibare vorm - zijn in Nederland geen specifieke normen vastgesteld. De redenatie hierbij is dat er een direct verband bestaat tussen concentraties zware metalen in diervoeding en concentraties zware metalen in mest. Lage concentraties zware metalen in diervoeding leidt tot lage concentraties zware metalen in dierlijke mest.

Het beleid ten aanzien van zware metalen in dierlijke mest lift bij toediening van dierlijke mest mee op de wetgeving rondom nutriënten (zie paragraaf 6.1.1). Concrete sturing op het afzetten van mest ten aanzien van zware metalen is er niet. De koppeling vindt feitelijk plaats door de maximalisering van de totale giften aan stikstof, fosfaat en kalium. Andere EU-landen of gebieden hanteren wel normeringen voor zware metalen in dierlijke mest zoals België en Groot-Brittannië. Duitsland en Denemarken gebruiken net als Nederland geen normeringen (Duitsland, Denemarken). Bij export van dierlijke mest(-producten) naar landen met dergelijke normeringen voor zware metalen moet hier wel rekening worden gehouden.

Ook voor compost (organische stof) en bodemverbeteraars hebben sommige landen normen voor maximale hoeveelheden zware metalen. In Nederland zijn er vrijwillige streef normen. Voor compost gelden de volgende maximale waarden voor zware metalen (in milligrammen per kilo droge stof): cadmium: 1, chroom:50, koper: 90, kwik: 0,3, nikkel:20, lood: 100, zink: 290 en arseen: 15 (Bron: LNV-loket). Hoe deze normen tot stand zijn gekomen is in het kader van deze studie niet onderzocht. Normaal gesproken wordt verhandelbare compost wel bemonsterd op stikstof, fosfor en kalium, maar niet op zware metalen.

Toevoer van zware metalen naar de bodem kan ook gebeuren via zuiveringsslib. Hiervoor zijn ook maximale waarden vastgesteld. Deze maximale waarden komen grotendeels overeen met die van compost (bron: LNV-loket). Het gebruik van zuiveringsslib als meststof wordt door het Besluit Overige 
Organische Meststoffen (BOOM) in Nederland niet toegepast. De EU-richtlijn voor zware metalen in zuiveringsslib kent veel hogere toelaatbare normen. Het Nederlandse beleid is dus op dit gebied veel stringenter. Hoe hier verder mee omgegaan wordt is niet helemaal duidelijk en niet verder onderzocht. De wetten en naleving hiervoor lijken in ontwikkeling te zijn.

Afzet dierlijke mest

De afzet van rundveemest vindt hoofdzakelijk plaats op het eigen bedrijf (melkvee- en overig rundvee). De afzet van varkensmest vindt doorgaans maar op een beperkt deel op het eigen bedrijf plaats. Veel mest vindt zijn weg maar akkerbouw- en opengrond tuinbouwbedrijven. Pluimveemest wordt voor een belangrijk deel verbrand in de biomassacentrale of geëxporteerd.

Voor vaste en vloeibare mest zijn in Nederland geen normen vastgesteld voor maximale toelaatbare gehalten aan zware metalen die in de mest zitten. De redenatie hierbij is dat diervoeding in principe schoon moet zijn en hierdoor de mest ook schoon is. Voor de aanpak van de te hoge uitstoot van zware metalen vanuit de landbouw is vooral regelgeving ingezet. Medio 2000 zijn de normen voor het toevoegen van koper en zink in mengvoeders verscherpt (EU Kaderrichtlijn Water 2000/60/EG), met als gevolg dat de belasting met koper en zink fors is afgenomen. In 2013 en 2014 heeft de NVWA signaleringsonderzoeken uitgevoerd in de vleesvarkenshouderij. Daaruit bleek dat ruim een derde van de bedrijven varkensvoer met te hoog koper voerde aan varkens van 12 weken en ouder. Naar aanleiding hiervan is de NVWA in september 2015 begonnen met extra inspecties op vleesvarkensbedrijven om de wettelijke toegestane norm voor koper in het voer te controleren. Bedrijven die de toegestane norm overtreden krijgen een boete van 5.000 euro. (www.nvwa.nl)

\section{Zware metalen in water}

In 2006 is de Europese Kaderrichtlijn Water (KRW) geïmplementeerd, waarbij alle aangewezen gronden oppervlaktewateren moeten voldoen aan chemische en ecologische doelen. Zware metalen zijn daarbij aangewezen als prioritaire stoffen waarvoor normeringen voor concentraties in de aangewezen wateren zijn vastgelegd. In de verschillende stroomgebiedsbeheerplannen (SGBP's) worden maatregelen vastgelegd om de doelen van de KRW te realiseren. De uitvoering van de eerste generatie SGBP's zijn in 2015 geëindigd. De tweede generatie SGBP's zijn in werking getreden voor de periode van 2016-2021.

In 2015 zijn op vele honderden meetpunten analyses gedaan op het voorkomen van allerlei stoffen en of ze aan de normen voldoen. Dit betrof 75 stoffen, waaronder zware metalen. Voor 25 stoffen zijn overschrijdingen aangetroffen.

Wat de zware metalen betreft werden in de watermonsters geen overschrijdingen vastgesteld van nikkel, chroom, kwik, lood en cadmium. Wat de andere metalen betreft voldoet zink het minst aan de norm (43\% voldoet niet) en in mindere mate arseen en koper (respectievelijk 12\% en $8 \%$ ).

(Bron: Compendium voor de Leefomgeving)

Naast de metalen die zich in het water bevinden zijn veel zware metalen in de loop der jaren bezonken op de bodem van het gehele watersysteem. In veel slib zitten hoge concentraties zware metalen. Deze stoffen bevinden zich soms al eeuwen op de bodem van deze systemen. Deze stoffen zijn vooral afkomstig geweest van het vroeger ongezuiverd of beperkt gezuiverd afvoeren van huishoudelijk en industrieel afvalwater. Soms worden dergelijke plekken lokaal gesaneerd (onder meer Hollandse IJssel, Biesbosch, Gelderse IJssel).

Voor het toedienen van dierlijke mest als input/grondstof liften zware metalen mee op de mestwetgeving die gericht is op nutriënten en gewasbeschermingsmiddelen. In de Europese Unie zijn voor lood, cadmium, kwik, arseen en tin maximum toegelaten gehalten in levensmiddelen vastgesteld zie de Europese verordening nr. 1881/2006 inzake vaststelling van maximum gehalten aan bepaalde verontreinigingen in levensmiddelen. Deze gelden voor levensmiddelen zoals vlees, orgaanvlees, granen, en groenten. Voor de zware metalen cadmium en kwik is door de Europese Voedselveiligheid Autoriteit (EFSA) een toelaatbare dagelijkse inname (TDI) vastgesteld. De Nederlandse Voedsel en Warenautoriteit voert controles uit op de levensmiddelen.

Het bestaande instrumentarium voor zware metalen is samengevat weergegeven in Tabel 6.5. 
Tabel 6.5

Zware metalen: duiding bestaande instrumenten aan de hand van RESET-model a)

\begin{tabular}{|c|c|c|c|c|c|}
\hline Instrument & Doel & $\mathbf{R}$ & Es & S : & $E \mathrm{~T}$ \\
\hline $\begin{array}{l}\text { Mestwetgeving (dierlijke mest en kunstmest) voor } \\
\text { akker- en tuinbouwbedrijven }\end{array}$ & $\begin{array}{l}\text { Zware metalen liften mee op normen voor } \\
\text { nutriënten }\end{array}$ & $x$ & & & \\
\hline Controle overschrijding diervoeders & Reguleren van gehaltes & $x$ & & $x$ & \\
\hline Activiteitenbesluit (voorheen Lozingenbesluit) & $\begin{array}{l}\text { Beperkt ijzer in lozingswater en metalengebruik in } \\
\text { varkenshouderij }\end{array}$ & $x$ & & & \\
\hline VAMIL/MIA & Milieuvriendelijke technieken & & & & $x$ \\
\hline Europese verordening nr. 1881/2006 & $\begin{array}{l}\text { Vaststelling van maximumgehalten bepaalde stoffen } \\
\text { in levensmiddelen }\end{array}$ & $x$ & & & \\
\hline TDI-normen EFSA & Gehalten cadmium en kwik (controles door NVWA) & $x$ & & $x$ & \\
\hline
\end{tabular}

a) Regels, Educatie, Sociale druk, Economische incentives en Tools

\subsection{Beoordeling bestaande instrumenten}

- Regelgeving is zeer effectief gebleken voor het terugdringen van emissies, bijvoorbeeld voor regulering grondontsmetting, activiteitenbesluit milieubeheer en stikstof-/fosfaatnormen. De regelgeving werd voorafgegaan door kennisontwikkeling en kennisverspreiding, waardoor de bedrijfsvoering kon worden aangepast zonder dat het leidde tot hoge kosten of andere problemen.

- Weinig financiële instrumenten (anders dan boetes bij overtreden van regelgeving) zijn gericht op individuele bedrijf binnen een sector. Wel maken de land- en tuinbouw in het algemeen, en specifieke sectoren in het bijzonder, kosten om te voldoen aan regelgeving en de emissie van schadelijke stoffen te beperken.

- Er zijn enkele subsidies en fiscale instrumenten ter bevordering van het gebruik van integraal duurzame productiesystemen.

Specifieke opmerkingen per categorie van stoffen

- Nutriënten

- Vooral veel regelgeving

- Aantal subsidies, fiscale instrumenten en quota

- Gewasbeschermingsmiddelen en biociden

- Vooral regelgeving en educatie

- Aantal economische incentives is beperkt

- Provisie op omzet bij middelenhandel (perverse prikkel)

- Verwerking van advieskosten in middelprijs (in-transparantie)

- Diergeneesmiddelen

- Mix van instrumenten gericht op vooral educatie, sociale druk en tools

- Geen economische incentives

- Regelgeving is gericht op zorgvuldig gebruik van diergeneesmiddelen, niet op terugdringen van hoeveelheden

- Autoriteit Diergeneesmiddelen speelt sinds 2011 een belangrijke rol door voortdurend het middelengebruik te evalueren en waar nodig normen aan te scherpen

- Zware metalen

- Voor dierlijke mest als input/grondstof liften zware metalen mee op de mestwetgeving die gericht is op nutriënten en gewasbeschermingsmiddelen. 


\section{$7 \quad$ Nieuwe financiële en overige instrumenten}

In dit hoofdstuk vindt een verdere verdieping plaats in de mogelijke rol van nog niet gebruikte (financiële) instrumenten. Het (potentiële) effect van afzonderlijke maatregelen is kwalitatief beoordeeld op basis van literatuur en expertkennis. Op grond van de evaluatie van de individuele stoffen per ketenschakel uit Bijlage 1 worden de mogelijke instrumenten generiek toegelicht.

Voor de beschrijving van de mogelijke toepasbaarheid van financiële en andere instrumenten in de keten is deze opgesplitst in de volgende vier onderdelen (Figuur 7.1).
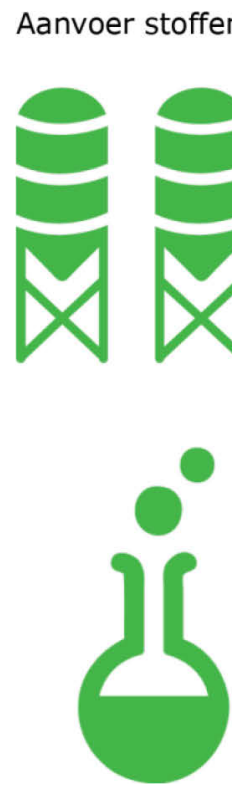

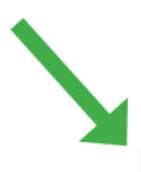

Bedrijfsopzet
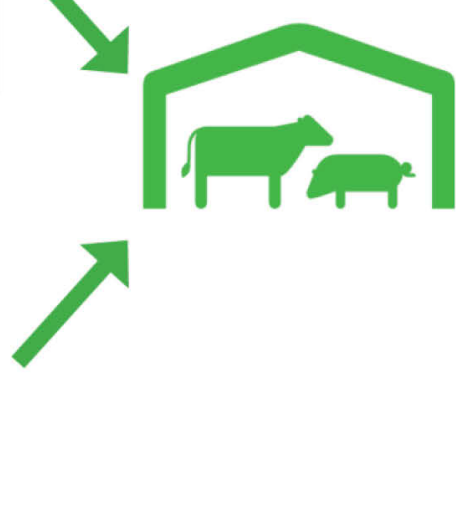

Afvoer van

hoofdproducten

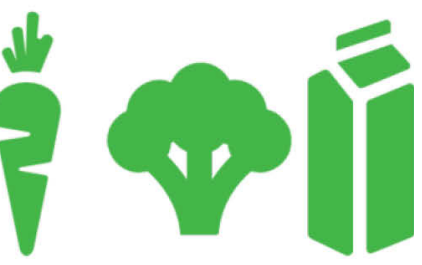

Afvoer van rest-/ bijproducten en afval a)
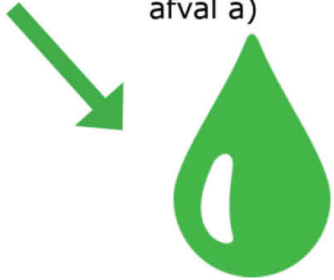

Figuur 7.1 Ketenonderdelen

a) inclusief de emissies / lozingen van milieubelastende stoffen die het watermilieu belasten

\subsection{Aanvoer stoffen}

De volgende instrumenten komen als mogelijkheid uit de evaluatie naar voren: Prijspremie, Subsidies, en Belasting of heffing. Belangrijkste instrument dat kan bijdragen aan het 'vervuiler betaalt'-principe zijn heffingen op nutriënten en middelen met hoge milieurisico's.

\section{Prijspremie}

Prijspremie betreft vooral het goedkoper maken van alternatieven. Het voordeel is dat op alle vijf beoordelingscriteria een positieve score wordt gegeven. Belangrijkste nadeel is dat op ketenpartijen op de een of andere manier middelen moeten zien te vinden om deze prijspremie te financieren. Gezien de kosten van het ontwikkelen van alternatieven willen producenten van alternatieven vaak wel duidelijkheid over de stabiliteit van de beleidsomgeving. Het moet voor hen duidelijk zijn dat ze de tijd zullen krijgen om hun investering terug te verdienen. Alle gebruikers profiteren naar rato van gebruik van deze stoffen. Draagt niet bij aan het 'vervuiler betaalt'-principe.

\section{Subsidies op alternatieven}

Voor subsidies geldt hetzelfde als voor prijspremies met het grote verschil dat nu de overheid middelen moet reserveren. Dit draagt niet bij aan het 'vervuiler betaalt'-principe. 


\section{Belasting of heffing}

Bij het ontbreken van een alternatief is de verwachting dat implementatie van deze maatregel zal leiden tot kostenverhoging voor de ondernemer. De verwachting is dat dit zal leiden tot minder gebruik en dus minder emissie van schadelijke stoffen indien er goede en kosteneffectieve alternatieven beschikbaar zijn. Alle gebruikers betalen naar rato van gebruik mee aan de belasting of heffing. Draagt wel bij aan het 'vervuiler betaalt'-principe.

De meest voor de hand liggende afdracht en grondslag voor een eventuele heffing op gewasbeschermingsmiddelen is op de prijs of hoeveelheid bij een verkoop-/aankooptransactie tussen een producent/leverancier van gewasbeschermingsmiddelen en een in Nederland gecertificeerd bedrijf, of bij de verkoop-/aankooptransactie tussen een gecertificeerd bedrijf en een Nederlandse eindgebruiker. Echter, gebaseerd op ervaringen in andere landen en schattingen van de prijsgevoeligheid van de vraag uit het verleden, lijkt de vraag naar gewasbeschermingsmiddelen prijsinelastisch te zijn. Dit betekent dat er beperkt gereageerd wordt op een verhoging van de prijs. Dit sluit effecten op het gebruik niet uit, maar voor een vermindering van het gebruik van bijvoorbeeld $50 \%$ zou op basis van bestaande schattingen van de prijselasticiteit een heffing in de orde van grootte van (minimaal) $100 \%$ tot $500 \%$ nodig zijn (Hof et al., 2013).

\subsection{Bedrijfsopzet}

De volgende instrumenten komen als mogelijkheid uit de evaluatie naar voren:

- subsidies

- belasting of heffing

- kortingen op heffingen

- (verhogen van) boetes bij overschrijden van grenzen

- braak-/leegstandprogramma's

- verzekeringen

- (verhandelbare) quota.

\section{Subsidies}

Hierbij valt vooral te denken aan subsidies voor maatregelen die leiden tot een efficiënter gebruik van bijvoorbeeld nutriënten of tot productiewijzen die het niet of minder nodig maken schadelijke stoffen in te zetten. Kan worden toegepast bij het bevorderen van implementatie van nieuwe technologieën, bijvoorbeeld op het gebied van aanpassingen aan klimaatregeling of aanpassingen aan stalopzet. Voorbeelden zijn de VAMIL/MIA regeling. Draagt niet bij aan het 'vervuiler betaalt'-principe.

\section{Belasting of heffing en Kortingen op heffingen}

Bedrijven binnen een hele sector of bedrijven met een bedrijfsopzet die resulteert in de uitstoot van schadelijke stoffen worden specifiek belast met een heffing of belasting.

Als aanvulling op het voorgaande: indien een bedrijf kan aantonen dat de uitstoot lager is dan de aangenomen uitstoot is het mogelijk een korting op de heffing te krijgen. Uitdagingen hierbij zijn:

a. wie levert de bewijslast dat de uitstoot lager is en

b. administratieve lasten voor zowel bedrijf als overheid.

Dit draagt indirect wel bij aan het 'vervuiler betaalt'-principe.

Voorbeelden zijn hogere heffingen bij onvoldoende implementatie van emissiebeperkende maatregelen op een bedrijf. Een ander voorbeeld is een 'forfaitaire heffing' die gebaseerd is op het aantal hectaren landbouwgrond dat een ondernemer in eigendom heeft. De stelling daarbij is dat op landbouwgronden in beginsel altijd meststoffen en gewasbeschermingsmiddelen worden gebruikt. Op basis van die stelling voer je een forfaitaire heffing in. Vervolgens creëer je een mogelijkheid dat ondernemers die kunnen aantonen dat zij minder of geen meststoffen (kunstmest, dierlijke mest) gebruiken een korting krijgen op de heffing of helemaal worden vrijgesteld. Hetzelfde is mogelijk met diergeneesmiddelen. Draagt wel bij aan het 'vervuiler betaalt'-principe. 
(Verhogen van) boetes bij overschrijden van grenzen

Verondersteld dat er grenzen zijn waarbinnen geproduceerd mag worden, zijn het verhogen van heffingen en het uitdelen van boetes financiële maatregelen die toegepast kunnen worden. Het controleren en handhaven van de bedrijven kan een substantiële inspanning van het ambtelijk controle apparaat vormen. Het is een maatregel die wel bijdraagt aan het 'vervuiler betaalt'-principe.

\section{Braak/leegstand programma's}

Het stilleggen van een gedeelte van de productiecapaciteit is een maatregel die toegepast kan worden als er een maximale hoeveelheid aan productie of emissie van vervuilende stoffen gesteld wordt. Het is voor bedrijven zeer kostbaar om delen van hun productiecapaciteit tijdelijk uit productie te halen. In het verleden zijn dit soort maatregelen onder andere toegepast in de akkerbouw binnen een totaal pakket met een flankerend beleid van subsidies en steunmaatregelen. Draagt niet bij aan het 'vervuiler betaalt'-principe.

\section{Verzekeringen}

Het niet of zeer beperkt toepassen van bijvoorbeeld gewasbeschermingsmiddelen heeft mogelijk grote gevolgen bij een uitbraak van een ziekte of plaag. Er kan sprake zijn van substantieel productieverlies en van afwaardering van aangetaste producten. Een verzekering kan de meest ernstige financiële gevolgen van een uitbraak mogelijk beperken. De mogelijke toepasbaarheid van premiesubsidie via artikel 68 vanuit het GLB staat beschreven in paragraaf 3.2.2. Draagt niet bij aan het 'vervuiler betaalt'-principe.

\section{(Verhandelbare) quota}

Verhandelbare quota zijn een middel dat wordt ingezet om de totale omvang van bijvoorbeeld de dierlijke productie in een sector te reguleren (dierrechten, fosfaatquotum, melkquotum). Een belangrijk nadeel van dit soort quota is dat er binnen een sector geen verschil in bedrijven wordt gemaakt en bedrijven zullen geneigd zijn hun (dure) quotum maximaal te vullen. Quota op productierechten dragen bij aan de beperking van de emissie van vervuilende stoffen. Tijdens transacties vindt er vaak een korting op de verhandelde rechten plaats. Het totale quotum zal hierdoor afnemen. De waarde van de rechten kan bedrijven doen besluiten deze waarde te verkopen en de productie te staken. De rechten zullen dan worden overgedragen aan bedrijven die willen uitbreiden. Als het mogelijk is door maatregelen de productie efficiënter te laten verlopen zullen er waarschijnlijk meer dieren gehouden worden om deze ruimte te vullen.

Er zitten nadelen aan het stellen van quota aan het gebruik van vervuilende stoffen als gewasbeschermingsmiddelen of antibiotica. Dreigende overschrijding van een dergelijk quotum zou kunnen leiden tot het onthouden van adequate zorg aan dier of plant, met mogelijk nadelige gevolgen voor diergezondheid en dierenwelzijn en het risico van uitbraken van grootschalige ziekten en plagen. Ook kan het leiden tot illegale import van middelen. Draagt beperkt bij aan het 'vervuiler betaalt'principe.

\subsection{Afvoer van hoofdproducten}

De volgende instrumenten komen als mogelijkheid uit de evaluatie naar voren: Prijspremie, Subsidies Verhogen/boetes bij overschrijden van grenzen.

\section{Prijspremie}

Op het ogenblik zijn er verschillende initiatieven op het gebied van het uitbetalen van een hogere prijs als een product zonder of met zeer weinig vervuilende stoffen geproduceerd wordt. Voor een aantal producten blijkt het mogelijk dit productkenmerk in de markt tot waarde te brengen. Voorbeelden zijn nieuwe productconcepten als 'Tasty Tom' bij tomaten en antibioticavrij geproduceerd varkensvlees. Echter, over het algemeen is men zeer terughoudend bij het promoten van 'the absence of a bad' omdat dit een diskwalificatie impliceert van de reguliere producten die ook voldoen aan de eisen die rond voedselveiligheid gesteld worden en waarbij volgens alle wettelijke voorwaarden geproduceerd is. Draagt niet bij aan het 'vervuiler betaalt'-principe. 


\section{Subsidies}

Hiervoor geldt grotendeels hetzelfde als voor een prijspremie. Bij een subsidie is er naast de extra kosten voor de overheid ook nog de kans op verwijten van ongeoorloofde staatsteun aan bepaalde sectoren. Draagt niet bij aan het 'vervuiler betaalt'-principe.

Verhogen/boetes bij overschrijden van grenzen

In Europa en Nederland is er zeer stringente regelgeving op het gebied van limieten voor middelen op producten. Bij overschrijden van normen op of in het product van bijvoorbeeld antibiotica of gewasbeschermingsmiddelen vinden er zeer strenge sancties plaats waaronder het ongeschikt verklaren van het product voor humane consumptie. Draagt niet bij aan het 'vervuiler betaalt'-principe.

\subsection{Afvoer van rest-/bijproducten en afval}

De volgende instrumenten komen als mogelijkheid uit de evaluatie naar voren:

- subsidies

- belasting of heffing

- kortingen op heffingen

- (verhogen van) boetes bij overschrijden van grenzen

- braak-/leegstandprogramma's

- (verhandelbare) quota.

\section{Subsidies}

Subsidie op emissiebeperkende maatregelen, bijvoorbeeld mestverwerking, kunnen bijdragen aan de versnelde implementatie van emissiebeperkende maatregelen. Vooral in de beginfase van de introductie van maatregelen helpen deze subsidies om een grotere groep ondernemers tot adoptie van een technologie over te laten gaan. De kosten voor de overheid zijn aanzienlijk.

Voorbeeld: Binnen POP3 kunnen landbouwers subsidie aanvragen voor duurzame maatregelen die waterverontreiniging tegengaan of bijdragen aan een goede waterhuishouding in hun gebied. Denk aan het toepassen van zuiveringsvoorzieningen (bijvoorbeeld helofytenfilters) om erfafspoeling tegen te gaan, kennis opdoen van technieken als rijenbemesting en deze toepassen, peilgestuurde drainage en inrichting van natuurvriendelijke oevers langs watergangen. Per regio wordt bepaald welke maatregelen daar het beste passen. Een gebiedsgerichte aanpak waarin de verschillende problemen in samenhang worden bekeken biedt het meeste perspectief. Hiervoor is het nodig dat de landbouwsector samen met het waterschap en de provincie om tafel gaat om dit uit te werken.

Een ander voorbeeld is een subsidie op het inrichten van een waterzuivering op een glastuinbouwbedrijf. De kosten voor de overheid zijn aanzienlijk. Draagt niet bij aan het 'vervuiler betaalt'-principe.

\section{Belasting of heffing en Kortingen op heffingen}

Het gaat hier om een belasting of heffing op de hoeveelheid vervuilende stoffen in mest of afvalwater. Naast generieke heffingen gericht op alle bedrijven in een sector is het mogelijk om specifieke heffingen op basis van de werkelijk geëmitteerde hoeveelheid vervuilende stoffen op te leggen. Indien kortingen op heffingen bij lage emissie worden toegepast veronderstelt dit dat er heffingen zijn waarop korting kan worden gegeven en dat deze heffingen dermate hoog zijn dat een korting een substantiële omvang kan aannemen. Bovendien is er een uitgebreid controle- en handhavingsapparaat nodig. Draagt wel bij aan het 'vervuiler betaalt'-principe.

(Verhogen van) boetes bij overschrijden van grenzen

Het gaat hier om boetes bij hoge gehaltes in mest of afvalwater. Dit vereist een uitgebreid controleen handhavingsapparaat. Draagt wel bij aan het 'vervuiler betaalt'-principe. 


\section{(Verhandelbare) quota}

Emissierechten kunnen gebruikt worden om de totale emissie te verminderen. Echter, zoals in voorgaande schakels gemeld, zijn er sterke incentives bij ondernemers om deze quota ook maximaal uit te nutten, zeker als ze een behoorlijke economische waarde vertegenwoordigen. Draagt beperkt bij aan het 'vervuiler betaalt'-principe. 


\section{Discussie en conclusies}

\subsection{Discussie}

In deze paragraaf worden (niet uitputtend) enkele aandachtspunten besproken.

\section{Slim samenspel van maatregelen}

De beschreven beleidsinstrumenten komen het beste tot hun recht als er sprake is van volgtijdelijkheid en samenspel tussen instrumenten en belanghebbenden. Als zich een nieuw probleem aandient dat mogelijk beleidsrelevant is, is de eerste stap vaak R\&D naar oorzaak en oplossing. Indien zich oplossingen aandienen die door bedrijven geadopteerd kunnen worden vindt vaak voorlichting en training plaats, waarbij de bedrijven geïnformeerd worden over de nieuwe mogelijkheden. Een aantal bedrijven zal overgaan tot vrijwillige adoptie van de maatregelen. Als de adoptie gepaard gaat met investeringen worden vaak subsidies verstrekt om de adoptie te versnellen. Ketenpartijen kunnen het voldoen aan bovenwettelijke maatregelen mogelijk gebruiken als competitief voordeel (met een hogere prijs voor hun producten) en primaire producenten met prijspremies verleiden tot aangepaste producten. Als het probleem voldoende ernstig is wordt overgegaan tot nieuwe of aanvullende regelgeving, al dan niet gepaard gaande met heffingen. Niet naleven van regelgeving/overschrijden van grenzen kan leiden tot boetes (Winsemius, 1986).

Aansluiten bij deze initiatieven en onderling afstemmen van extra instrumenten kunnen een bijdrage leveren aan het 'vervuiler betaalt'-principe en het ingezette beleid versterken. Er gebeurt al veel vanuit andere beleidsterreinen om het gebruik van de in dit rapport genoemde stoffen terug te dringen. Bij nutriënten gebeurt er veel om het overschrijden van het fosfaatplafond te voorkomen, en bij antibiotica om de volksgezondheidsrisico's van antibioticaresistentie te verminderen.

Belangrijk is dat nieuwe instrumenten niet geïsoleerd geïntroduceerd worden, maar in samenhang met andere nieuwe en bestaande instrumenten. Een ex ante evaluatie van voorgenomen beleid en continue monitoring van het ingezette beleid van een mogelijke set van oplossingen is daarbij belangrijk. Als er sprake is van diverse belanghebbenden en diverse instrumenten die elkaar beïnvloeden en onderling afhankelijk zijn is de uitkomst vaak onzeker.

Bij een slim samenspel van maatregelen kan worden gedacht aan bijvoorbeeld:

- slim akkerrandenbeheer

Als een akkerbouwer geen of minder gewasbeschermingsmiddelen gebruikt hoeft hij een minder groot gedeelte van de percelen als akkerranden in te richten, of wordt de vergoeding voor het akkerranden beheer hoger.

- Investeringen in emissiebeperkende maatregelen worden betaald door hogere heffingen bij alle bedrijven die emitteren.

- Onderzoek naar alternatieven voor gewasbeschermingsmiddelen of antibiotica wordt betaald door generieke heffingen op deze stoffen.

\section{Bonus-malussysteem}

Een typisch kenmerk van een bonus-malussysteem (dat veelal wordt toegepast bij verzekeringen) is dat de 'claim history' invloed heeft op de premiereductie. Naarmate er aantoonbaar sprake is van goed gedrag (bijvoorbeeld minder gebruik van bestrijdingsmiddelen of emissie van schadelijke stoffen) hoeft er minder heffing betaald te worden. De prestatie uit het verleden bepaalt de actuele heffing. Het is echter noodzakelijk dat er een eenduidige en onafhankelijke meting van bijvoorbeeld gebruik of emissie is. Een belangrijk nadeel van een bonus-malussysteem is informatie-asymmetrie: het bedrijf dat deelneemt aan het systeem weet vaak meer over het gebruik dan degene die de bonus of malus moet vaststellen.

Een voorbeeld van een samenspel van maatregelen is de introductie van een bonus-malussysteem zoals gesuggereerd door Guus Beugelink (2015) in Water Governance. Boeren die iets meer doen 
(meer milieumaatregelen treffen) hoeven minder (bijvoorbeeld watersysteemheffing) te betalen dan zij die niets doen. Degenen die wel maatregelen treffen, kunnen misschien zelfs een subsidie krijgen, die kan worden betaald uit de opbrengsten die ontstaan doordat de anderen, die niets doen, meer heffing betalen.

Een ander voorbeeld is uitbreiding van de verontreinigingsheffing met diffuse lozingen, bijvoorbeeld in de vorm van een forfaitaire heffing per hectare op het gebruik van (kunst)mest en bestrijdingsmiddelen, ervan uitgaande dat bestrijdingsmiddelen en (kunst)mest altijd worden gebruikt op landbouwgronden. Een boer die dat niet doet, krijgt vrijstelling.

Boetes of bonus: twee kanten van dezelfde medaille?

Het blijkt dat mensen het effect van winst en verlies niet als gelijk inschatten. Uit onderzoek van Kahneman en Tversky (1979) bleek dat de waarde die aan verlies wordt gehecht veelal groter is dan de waarde die wordt toegekend aan winst. Ondernemers zullen daarom naar verwachting meer moeite doen om een mogelijke heffing te voorkomen dan dat ze moeite zullen doen om een bonus of premie te verwerven. Door hier slim gebruik van te maken kan het effect van beleidsinterventies vergroot worden, namelijk door het zorgvuldig 'framen' van mogelijke financiële beleidsinstrumenten. Het initieel sterk verhogen van heffingen en ondernemers de mogelijkheid geven om een gedeelte van de heffing te vermijden lijkt in dit kader effectiever dan een lage heffing en het beschikbaar stellen van subsidies bij implementeren van aanvullende maatregelen.

\section{Uitgebreid controleapparaat}

Belangrijk nadeel bij een aantal instrumenten die gericht zijn op 'vervuiler betaalt', is dat er een uitgebreid controle- en handhavingsapparaat nodig is. Er zal de bereidheid en de capaciteit moeten zijn om te kunnen handhaven. De sanctiemaatregelen die ter beschikking staan moeten proportioneel zijn, zodat het instrument voldoende effectief is en ook het draagvlak bij bedrijven behouden blijft. Bij de controle zijn drie controlerende instanties betrokken:

- de NVWA, die de gebruikswetgeving van gewasbeschermingsmiddelen en meststoffen controleert

- de waterschappen, die de naleving controleren van regelgeving met betrekking tot de lozingen en emissies naar het water die door het gebruik van die stoffen worden veroorzaakt

- de Inspectie Verkeer en Leefomgeving, die de naleving van wet- en regelgeving voor een veilige en duurzame leefomgeving en transport stimuleert. Zij is op 1 januari 2012 ontstaan door samenvoeging van de Inspectie Verkeer en Waterstaat (IVW) en de VROM-inspectie.

De huidige mogelijkheden van toezicht bij deze controle-instanties zijn begrensd, mede door chronische ondercapaciteit. Daarom moet het toezicht risicogericht zijn en door kennis worden gedreven (www.rijksoverheid.nl), zodat mensen en middelen efficiënt en effectief worden ingezet. Uitbreiding van controletaken zal gepaard moeten gaan met uitbreiden van capaciteit. Naast publieke controle zouden ook private instellingen een gedeelte van de regelgeving kunnen controleren. Het is dan wel belangrijk dat deze private instellingen worden gecertificeerd, als 'garantie' dat zij hun handhavende taak naar behoren vervullen. Als aansluiting gezocht wordt bij private kwaliteitssystemen (zoals in de varkenshouderij op het gebied van antibioticagebruik) wordt het een gezamenlijk publiek-privaat belang.

\section{Perverse prikkels}

De Nederlandse landbouw produceert meer dierlijke mest dan ze kan afzetten binnen de huidige mestwetgeving. Er is meer aanbod dan vraag, zelfs als er rekening gehouden wordt met de huidige exportmogelijkheden van mest en mestproducten. Deze export is gebonden aan strenge regelgeving in de ontvangende landen. Bovendien is het exporteren van mest en mestproducten alleen lucratief als de transportkosten niet te hoog worden.

Het mestbeleid in Nederland is gericht op het beperken van het verlies van mineralen naar het gronden oppervlaktewater door het begrenzen van de hoeveelheid, de periode waarin en de wijze waarop mineralen worden toegediend aan de landbouwgrond (Willems et al., 2012). In de huidige situatie van de mestmarkt waarin het aanbod van mest (met mineralen) groter is dan de vraag zijn de kosten voor mestafzet hoog. De Nederlandse Vakbond Pluimveehouders en LTO Nederland geven in hun brief aan de Staatsecretaris van Economische Zaken dd. 18-12-2015 het volgende aan: 
'Niet-naleving van wet- en regelgeving op het gebied van meststoffen hangt onder andere samen met perverse prikkels veroorzaakt door hoge mestafzetkosten. De hoge kosten om mest af te zetten zorgen ervoor dat partijen in de mestmarkt zoeken naar wegen om mest goedkoper kwijt te raken.'

In de huidige situatie zijn de ondernemers met mestoverschot gebaat bij een maximale afzet van mest op eigen grond binnen de grenzen van de mestwetgeving (gebruiksnormen, fosfaatrechten enzovoort). Van het overschot moet minimaal 50\% verplicht worden verwerkt. De rest van de mest kan worden afgezet bij andere agrarische ondernemers (akkerbouwers of tuinders) die nog afzetruimte hebben. De kosten van de mestafzet bij de akkerbouwers en tuinders komen voor rekening van de ondernemer met het mestoverschot. De akkerbouwers en tuinders zullen daarom ook zoveel mogelijk dierlijke mest willen toedienen waarvoor ze een vergoeding ontvangen. De ondernemers met het mestoverschot willen dat ook graag, omdat de mestafzet een goedkopere alternatief is dan mestverwerking. Kortom, er zijn sterke (financiële) prikkels om zoveel mogelijk dierlijke mest te gebruiken in delen van de landbouw zonder rekening te houden met de behoefte van gewassen.

Vanuit economisch perspectief is er dus geen prikkel om zuinig om te gaan met meststoffen (nutriënten en zware metalen). Daarnaast geven Luesink et al. (2007, 113-114) aan dat bij hoge tarieven van mestafzet de ontvangers van dierlijke mest gebaat zijn bij lage gehaltes van nutriënten in de mest om zo zoveel mogelijk mest te kunnen toedienen, terwijl met name de varkenshouderij inspanningen pleegt om de nutriëntconcentraties van de mest te verhogen.

Voor pluimveemest zijn er inmiddels alternatieven. Met de komst van de biomassacentrale in Moerdijk is het verwerken van mest tot energie en mineralenproducten een lucratief alternatief voor mestafzet. Een ander deel van de droge pluimveemest wordt elders verwerkt en geëxporteerd. Voor varkensmest worden de verwerkingsalternatieven ook steeds aantrekkelijker, maar is er nog geen sluitend verdienmodel. Rundermest is de minst nutriëntrijke meststroom, die met name als dierlijke mest wordt toegediend en afgezet.

\section{Snelle winst en lange adem}

Snelle winst is te behalen door aan te sluiten op bestaande regelingen. Bijvoorbeeld het sterk verhogen van bestaande heffingen en het gelijktijdig introduceren van reducties op deze heffingen bij bewezen goed gedrag c.q. het effectief implementeren van emissiereducerende maatregelen zijn waarschijnlijk maatregelen die sneller en makkelijker te implementeren zijn dan maatregelen waarbij wetgeving moet worden aangepast. Het opstarten van maatregelen die gepaard moeten gaan met aanvullende wet- en regelgeving zijn een zaak van lange adem. Bovendien is het dan cruciaal dat de samenhang van de verschillende maatregelen bewaakt wordt. Vaak zijn diverse departementen en beleidsdirecties op verschillende niveaus bij een samenspel van maatregelen betrokken, echter de maatregelen worden ieder voor zich in de politieke arena beoordeeld en geamendeerd. Naarmate de beleidsvrijheid en de mogelijkheden voor maatwerk groter worden, nemen de fiscaal-juridische risico's echter toe. Deze kunnen mogelijk ondervangen worden door de maatwerkoplossing niet te regelen in de zuiveringsheffing, maar in de vorm van een subsidie. De subsidie zou dan qua voorwaarden wel elementen kunnen bevatten van bijvoorbeeld de bonus-regeling voor goed verwerkbaar afvalwater. Dat versterkt ook de duurzaamheidsargumenten richting EU, op basis waarvan de subsidie mogelijk juist eerder onder een vrijstellingsregeling kan worden gebracht of goedkeuring is te verkrijgen.

\section{Koppelen van heffingen aan subsidies}

Het lijkt aantrekkelijk om subsidies en heffingen aan elkaar te koppelen, bijvoorbeeld door het financieren van subsidies met de opbrengsten van opgelegde heffingen. In de praktijk zijn er echter vaak verschillende ministeries bij betrokken en is deze koppeling niet zo makkelijk te creëren. Het blijkt lastig om heffingen te 'oormerken' als financieringsbron. Een mogelijkheid zou zijn om dergelijke initiatieven te laten uitvoeren door producentenorganisaties. Bijvoorbeeld een generieke heffing per aanwezig dier of areaal oppervlakte en het gebruikmaken van een deel van deze heffingen om de implementatie van alternatieve concepten te subsidiëren. Echter, de 'algemeen verbindend verklaring' die het voor deze organisaties mogelijk moet maken om bij alle ondernemers in een sector een heffing op te leggen ontbreekt nog steeds. Een andere manier om heffingen en subsidies te koppelen is bijvoorbeeld via waterschappen. 
Een voorbeeld van een instrument dat vanaf 2015 wordt ingezet in de glastuinbouw om de $\mathrm{CO}_{2}-$ emissie terug te dringen betreft het Energie Besparingssysteem Glastuinbouw (EBG). Dit is een afspraak tussen de glastuinbouwsector en de rijksoverheid met als doel de $\mathrm{CO}_{2}$-emissie op sectorniveau te vertalen naar individuele bedrijven. Het EBG volgt de ontwikkeling van het gasverbruik per bedrijf. Dit wordt jaarlijks vergeleken met het toegestaan gasverbruik (de norm) en daaruit volgt een verrekening per bedrijf. De opbrengsten uit het EBG worden gebruikt voor de financiering van het programma 'Kas als Energiebron'. Dit is een innovatie- en actieprogramma van het ministerie van EZ en LTO Glaskracht Nederland voor de gehele glastuinbouwsector in Nederland en streeft ernaar de doelen van de glastuinbouw voor energiebesparing en minder $\mathrm{CO}_{2}$-uitstoot binnen bereik te brengen.

En nu hoe verder?

Uit het voorgaande blijkt dat voor een effectief beleid niet een silver bullet van één maatregel zal resulteren in het gewenste effect. Er zal een slimme combinatie gemaakt moeten worden van financiële instrumenten en andere onderdelen van het RESET-model.

Belangrijk is een goede ex-ante evaluatie van een voorgenomen set van maatregelen. Niet alleen via klassieke instrumenten als Tafel van Elf en uitgebreide stakeholderconsultatie, maar ook door het slim koppelen van mathematische emissievoorspellende modellen als STONE (Samen Te Ontwikkelen Nutriënten Emissiemodel), het consensusmodel voor landelijke emissieberekeningen, MAMBO (Mest en Ammoniak Model voor Beleidsondersteunend Onderzoek) en economische modellen en technieken uit de gedragseconomie. Hierdoor kan inzicht worden gekregen in de mogelijke milieueffectiviteit, de financiële kosten en baten van verschillende scenario's. Perspectiefrijke opties kunnen voor implementatie uitgetest worden met behulp van 'lab in field'-experimenten. ${ }^{9}$ Eén van de zaken die uitgetest moeten worden is de prijselasticiteit van het gebruik van vervuilende stoffen bij prikkels van verschillende sterkte.

\subsection{Conclusies}

Conclusies met betrekking tot bestaande instrumenten:

- Er zijn in de diverse ketens al veel instrumenten ingezet om de uitstoot van nutriënten, gewasbeschermingsmiddelen en biociden, diergeneesmiddelen, en zware metalen te beperken.

- Slechts weinig van de bestaande instrumenten zijn economische instrumenten en er zijn weinig financiële instrumenten die bijdragen aan het 'vervuiler betaalt'-principe, zoals gehanteerd in dit onderzoek. Wel maken de land- en tuinbouw in het algemeen en specifieke sectoren in het bijzonder kosten om aan de wetgeving te voldoen en de emissie van schadelijke stoffen te beperken. In de plantaardige productie is bijvoorbeeld onder druk van regelgeving succesvol geïnvesteerd in emissiebeperkende maatregelen voor gewasbeschermingsmiddelen. Er zijn enkele subsidies en fiscale instrumenten ter bevordering van het gebruik van integraal duurzame productiesystemen.

- Regelgeving is zeer effectief gebleken voor het terugdringen van emissies, bijvoorbeeld voor regulering van grondontsmetting, of het Activiteitenbesluit milieubeheer. De regelgeving werd voorafgegaan door kennisontwikkeling en kennisverspreiding, waardoor de bedrijfsvoering kon worden aangepast zonder dat het leidde tot hoge kosten of technische problemen.

Conclusies met betrekking tot nieuwe instrumenten:

- Er zijn mogelijkheden om met nieuwe financiële instrumenten meer invulling te geven aan het 'vervuiler betaalt'-principe, zoals gehanteerd in dit onderzoek. Een slimme combinatie van subsidies, heffingen en boetes kan bijdragen aan het verminderen van de belasting van het watermilieu, de financierbaarheid van het maatregelenpakket als ook aan de kostenterugwinning van het waterbeheer.

\footnotetext{
9 Lab in field-experimenten zijn experimenten waarbij actoren in zo reëel mogelijke situaties worden geplaatst, waarbij dan hun gedrag in die omstandigheden geobserveerd wordt.
} 
- De meest voor de hand liggende financiële instrumenten voor nadere analyse, instrumenten die aangrijpen op Bedrijfsopzet of Afvoer van rest-/bijproducten en afval inclusief lozingen en emissies, zijn:
a. Belasting of heffing
b. Kortingen op heffingen
c. (Verhogen van) boetes bij overschrijden van grenzen.

- Voor de meeste maatregelen is een samenspel tussen verschillende instrumenten noodzakelijk voor maximale effectiviteit. Dit betreft dan niet alleen financiële instrumenten maar ook andere instrumenten voor gedragsbeïnvloeding, zoals educatie, sociale druk, tools en wet- en regelgeving. Ook kan worden gedacht aan het doorgronden en corrigeren van de financiële prikkels (bijvoorbeeld provisie op omzet) van adviseurs van de bedrijven die vervuilende stoffen leveren.

- Aansluiten bij bestaande heffingen en subsidies lijkt voor de korte termijn mogelijkheden te bieden om snel aanvullende maatregelen te implementeren. 


\section{Literatuur, websites en interviews}

Arcadis, 2010. Verkenning innovatieve economische instrumenten voor agrarische watermaatregelen; overzicht van praktijksituaties.

Bemelmans-Videc, M.L., R.C. Rist en E.O. Vedung (eds.), 2003. Carrots, sticks and sermons: Policy instruments and their evaluation. Transaction Publishers, Piscataway.

Beugelink, G., 2015. SPRAAKWATER Herziening belastingstelsel waterschappen broodnodig, Water Governance, nummer 04/2015.

Bokma-Bakker en Bergevoet, 2011. Versterking van het diergezondheidsmanagement in de varkenshouderij: belemmeringen en oplossingsrichtingen, rapport 487.

Bosch, van den en Partners, Definitiedocument Duurzame financiering van het waterbeheer, van den Bosch en Partners, nov. 2015.

CBS, PBL en Wageningen UR, Compendium voor de Leefomgeving, 2013 en eerdere Jaren.

Duijnhoven, N. van, J. Klein, J. Rozemeijer en S. Loos, 2015. Toestand- en trendanalyse voor nutriënten op KRW-meetlocaties. Deltares-rapport 1220098-015-BGS-0001.

Ehlert, P.A.I. et al., 2013. Appraising Fertilisers: Origins of current regulations and standards for contaminants in fertilisers, Wettelijke onderzoekstaken natuur en milieu, werkdocument 336.

Europees Milieu Agentschap, 2008 (http://www.eea.europa.eu/nl/publications/92-9167-000-6sum/page001.html).

Europese Parlement en de Raad, Verordening (EG) Nr. 2003/2003 van 13 oktober 2003 inzake meststoffen.

EZ, 2013, brief van de staatssecretaris van Economische Zaken aan de Voorzitter van de Tweede Kamer der Staten-Generaal, Den Haag, 2 september 2013, Nr. 214, Gewasbeschermingsbeleid.

EZ, 2015, Kamerbrief Productiebegrenzende maatregelen in de melkveehouderij (https://www.rijksoverheid.nl/ministeries/ministerie-van-economischezaken/documenten/kamerstukken/2015/07/02/kamerbrief-productiebegrenzende-maatregelen-inde-melkveehouderij).

Gourley, C. J. P. en D. M. Weaver, 2012. 'Nutrient surpluses in Australian grazing systems: management practices, policy approaches, and difficult choices to improve water quality.' Crop and Pasture Science 63(9): 805-818.

Ham, A. van den, C.H.G. Daatselaar, G.J. Doornewaard en D.W. de Hoop, 2007. Eerste ervaringen met het Gebruiksnormenstelsel; Studie in het kader van de Evaluatie Meststoffenwet 2007. Den Haag, LEI, rapport 3.07.04.

Hof, B., C. Koopmans, W. Rougoor en J. van der Voort, 2013. Effecten en vormgeving van een heffing op gewasbeschermingsmiddelen, SEO-rapport nr. 2013-39.

Jansen, J., R. Wessels and T. Lam, 2012. How to R.E.S.E.T. farmer mindset? Experiences from the Netherlands. Countdown Symposium, 2012 dairy Australia, Melbourne. Pp. 23-27. 
Kahneman, D. en A. Tversky, 1979. Prospect Theory: An Analysis of Decision under Risk. Econometrica, Vol. 47, No. 2. (Mar., 1979), pp. 263-292.

Klein, J., 2012. Emissie van nutriënten vanuit de glastuinbouw - Nieuwe berekeningswijze EmissieRegistratie ronde 2011. Deltares, proj.nr. 1206111-010.

Koeijer, T.J. de, J.S. Buurma, H.H. Luesink, M.N.A. Ruijs, 2015. Beleid waterkwaliteit: kosten voor de landbouw: een quick scan. Nota/LEI Wageningen UR LEI 2015-147 - 17 p.

Lauwere, C.C. de, A. van den Ham, J Reijs, A. Beldman, G. Doornewaard, A.C. Hoes en B. Philipsen, 2015. Adviseurs over verduurzaming in de zuivelketen. LEI-rapport 2015-002. Wageningen UR, Wageningen/ Den Haag.

LEI, Landbouw Economisch Bericht, 2013

Luesink, H.H., P.W. Blokland, J.N. Bosma en M.W. Hoogeveen (2007). Monitoring mestmarkt 2007; Achtergronddocumentatie. LEI-Rapport 2008. ISBN/EAN 9789086152728.

Michie, S., M.M. van Stralen and R. West, 2011. The behaviour change wheel: a new method for characterising and designing behaviour change interventions. Implementation science 6 (42). http://www.implementationscience.com/content/6/1/42

Nolan, J.M., P.W. Schulz, R.B. Cialdini, N.J. Goldstein en V. Griskevicius, 2008. 'Normative social influence is underdetected'. Personality and Social Psychology Bulletin 34, 913-923.

Planbureau voor de Leefomgeving, 2014. Beoordeling Programmatische Aanpak Stikstof; de verwachte effecten voor natuur en vergunningsverlening, Den Haag.

Rijkswaterstaat, Waterdienst, Kostenterugwinning van Waterdiensten in Nederland, rapport 2008.051.

Planbureau voor de Leefomgeving, 2012. Evaluatie Meststoffenwet 2012. Syntheserapport http://www.pbl.nl/publicaties/2012/evaluatie-meststoffenwet-2012.

RIVM, 2002. MINAS en MILIEU, Balans en Verkenning. RIVM-rapport 718201005. http://www.pbl.nl/sites/default/files/cms/publicaties/718201005.pdf

Sterk Consulting en Bureau Buiten, Kostenterugverdiening van waterdiensten, Eindrapport, 2013.

Tobey, J. A. and H. Smets (1996). 'The Polluter-Pays Principle in the Context of Agriculture and the Environment.' World Economy 19(1): 63-87.

Twijnstra-Gudde en Tauw, 2015, Toekomstbestendige en duurzame financiering van het Nederlandse waterbeheer.

https://www.rijksoverheid.nl/binaries/rijksoverheid/documenten/rapporten/2015/07/03/rapporttoekomstbestendige-en-duurzame-financiering-waterbeheer/2015120656-01.pdf

Willems, J., M. van Schijndel, H. van Grinsven, F. Kragt, H. van Zeijts, J. van Dam, G.J. van den Born en S. van der Sluis, 2012. Evaluatie Meststoffenwet 2012: syntheserapport, Den Haag: Planbureau voor de Leefomgeving.

Winsemius, P., 1986, Gast in eigen huis - Beschouwingen over milieumanagement, Samson HD Tjeenk Willink, Alphen a/d Rijn. 


\section{Websites}

www.agrimatie.nl

www. bestrijdingsmiddelenatlas. $\mathrm{nl}$

www.cbs.nl (/NR/rdonlyres/66F168B9-7628-4FDE-AD09-

20BA7CF31364/0/2012benuttingstikstoffosforlandbouwart.pdf

www.compendiumvoordeleefomgeving.nl

www.fidin.nl (/Beleid/Gebruik/Cijfers)

www.kcwj.nl (/sites/default/files/Factsheet_Subsidie.pdf)

www.milieufocus.nl (/factsheets/d/de-vervuiler-betaalt.html)

www.monitoringmestmarkt.nl

www.ou.nl

www.pluimveeweb.nl (/artikelen/2014/01/antibiotica-belgie/)

www.overheid.nl (o.a. Meststoffenwet)

www.rijksoverheid.nl (o.a. toezichtkader NVWA)

\section{Interviews}

- Harry Leusink, LEI

- Philip Ehlert, Alterra

- Martha van Eerdt en Aaldrik Tiktak, PBL 


\section{Bijlage 1 Beoordeling van mogelijke nieuwe financiële instrumenten}

Per categorie schadelijke stoffen is een beoordeling gemaakt van de toepasbaarheid van verschillenden nieuwe financiële instrumenten. Daarbij worden de volgende beoordelingscriteria gebruikt (zie hoofdstuk 2 voor een nadere toelichting op de beoordelingscriteria):

- Doeltreffendheid

- Impact op overheidskosten

- Controleerbaarheid/handhaafbaarheid

- Draagvlak bij ondernemers

- Toekomstbestendigheid

Score per beoordelingscriterium:

- (-) een maatregel pakt ongunstig uit op het te beoordelen kernmerk. Bijvoorbeeld subsidies zullen leiden tot hogere overheidskosten en worden daarom gescoord met een min op dit criterium.

- (+) een maatregel pakt gunstig uit op het te beoordelen kernmerk. Bijvoorbeeld subsidies zullen leiden tot hogere ondernemersinkomens en worden daarom gescoord met een plus op het onderdeel draagvlak ondernemers.

- (0) Het is niet de verwachting dat een maatregel effect heeft op dit beoordelingscriterium.

- (nvt) Indien een bepaald financieel instrument niet van toepassing is op deze ketenschakel wordt dat aangegeven met 'n.v.t.'. Bijvoorbeeld bij de aanvoer van gewasbeschermingsmiddelen zijn Braak/leegstand-programma's niet toepasbaar. Als opties theoretisch wel mogelijk zijn maar de implementatie onwaarschijnlijk lijkt zijn ze toch beschreven.

In de hierna volgende tabellen zijn mogelijke financiële instrumenten aan de hand van bovengenoemde criteria beoordeeld voor het reduceren van de emissies van nutriënten naar water (Tabel B1.1), gewasbeschermingsmiddelen (Tabel B1.2), diergeneesmiddelen (Tabel B1.3) en zware metalen (Tabel B1.4). In Tabel B1.5 en B1.6 worden enkele aanvullende instrumenten weergegeven voor respectievelijk gewasbeschermings- en diergeneesmiddelen. Tabel B1.7 geeft een indicatie hoe het RESET-model gebruikt kan worden voor nieuw beleid voor zware metalen. 
Tabel B1.1

Beoordeling van mogelijke nieuwe financiële instrumenten om emissies van nutriënten reduceren aan de hand van de vijf beoordelingscriteria

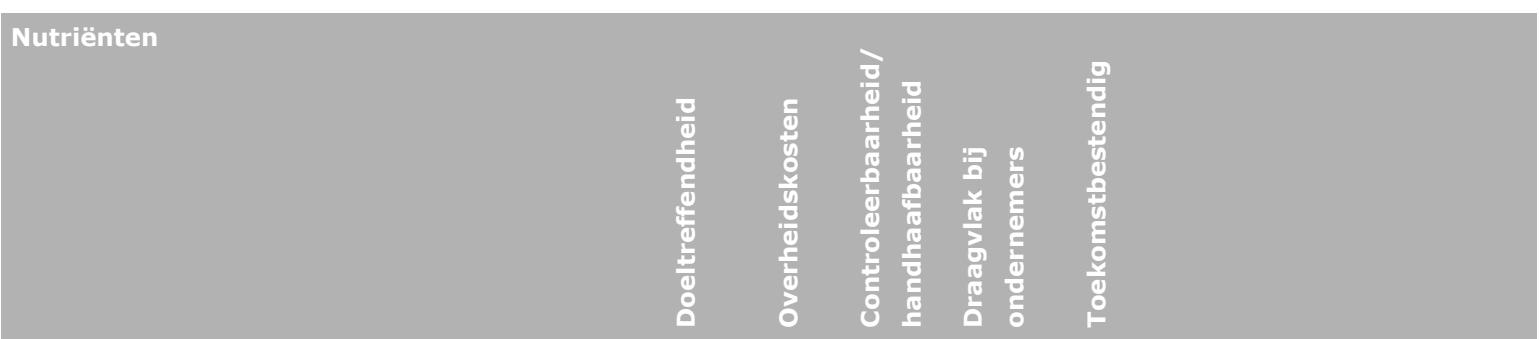

\begin{tabular}{|c|c|c|c|c|c|c|c|}
\hline Aanvoer & & & & & & & \\
\hline instrument & omschrijving & & & & & & Opmerkingen \\
\hline Prijspremie & $\begin{array}{l}\text { goedkoper maken van } \\
\text { alternatieven } \\
\text { bijvoorbeeld speciale } \\
\text { voeders (bijvoorbeeld } \\
\text { fytase) en kunstmest } \\
\text { met lage gehaltes }\end{array}$ & + & + & + & + & + & $\begin{array}{l}\text { wel hoge kosten voor } \\
\text { leveranciers (?) }\end{array}$ \\
\hline Subsidies & $\begin{array}{l}\text { subsidie op } \\
\text { alternatieven }\end{array}$ & + & - & + & + & + & $\begin{array}{l}\text { draagt het ook bij aan } \\
\text { principe 'vervuiler betaalt'? }\end{array}$ \\
\hline Belasting of heffing & $\begin{array}{l}\text { belasting bij } \\
\text { producent/importeur } \\
\text { op producten met } \\
\text { hoge gehaltes, } \\
\text { resulterend in hogere } \\
\text { aankoopprijs voor de } \\
\text { veehouder }\end{array}$ & 0 & + & + & - & 0 & $\begin{array}{l}\text { opbrengsten hiervan zouden } \\
\text { gebruikt kunnen worden voor } \\
\text { subsidies }\end{array}$ \\
\hline Kortingen op heffingen & $\begin{array}{l}\text { minder aanvoer } \\
\text { resulteert in minder } \\
\text { heffingen }\end{array}$ & + & - & + & + & + & $\begin{array}{l}\text { Goed controle apparaat } \\
\text { essentieel. Gevaar van fraude } \\
\text { en illegaal gebruik. }\end{array}$ \\
\hline $\begin{array}{l}\text { Verhogen/boetes bij } \\
\text { overschrijden van } \\
\text { grenzen }\end{array}$ & $\begin{array}{l}\text { te veel aanvoer } \\
\text { resulteert in hogere } \\
\text { heffing/boete }\end{array}$ & + & + & - & - & + & Zie vorige \\
\hline Belasting of heffing & heffing bij gebruik & + & + & - & - & + & $\begin{array}{l}\text { Heffing op aangevoerde } \\
\text { hoeveelheid } \mathrm{N} \text {-of } \mathrm{P}\end{array}$ \\
\hline Kortingen op heffingen & $\begin{array}{l}\text { minder heffing bij } \\
\text { toepassing } \\
\text { besparende } \\
\text { maatregelen }\end{array}$ & + & - & - & + & + & Zie omschrijving \\
\hline $\begin{array}{l}\text { Verhogen/boetes bij } \\
\text { overschrijden van } \\
\text { grenzen }\end{array}$ & $\begin{array}{l}\text { boete bij overschrijden } \\
\text { quota }\end{array}$ & + & + & - & $\begin{array}{c}0 \\
(+ \text { en } \\
-)\end{array}$ & + & $\begin{array}{l}\text { Veronderstelt } \\
\text { mineralenregistratie (zoals } \\
\text { MINAS); draagvlak } \\
\text { afhankelijk van efficiëntie }\end{array}$ \\
\hline $\begin{array}{l}\text { Braak/leegstand } \\
\text { programma's }\end{array}$ & $\begin{array}{l}\text { leegstand bij } \\
\text { naderende } \\
\text { overschrijding quota }\end{array}$ & + & + & - & - & - & $\begin{array}{l}\text { Dure maatregel voor de } \\
\text { bedrijven }\end{array}$ \\
\hline Verzekeringen & n.v.t. & & & & & & Niet toepasbaar \\
\hline
\end{tabular}


Veronderstelt

mineralenregistratie (zoals MINAS); draagvlak afhankelijk van efficiëntie; remt innovatie. Geen prikke tot efficiënte productie

Afvoer van hoofdproduct

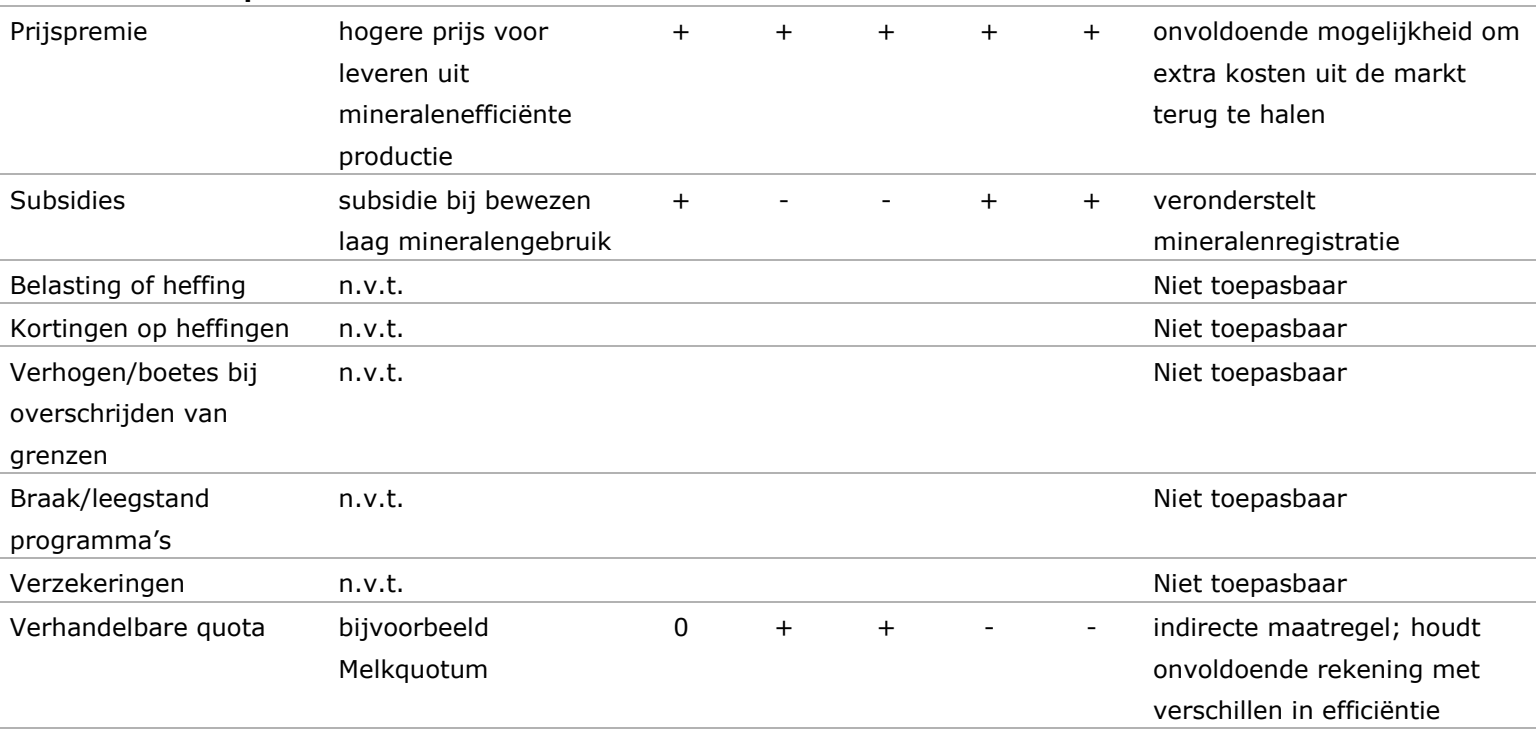

Afvoer van bijproduct/afval (gewassen gebruikt als organische mest en dierlijke mestafzet)

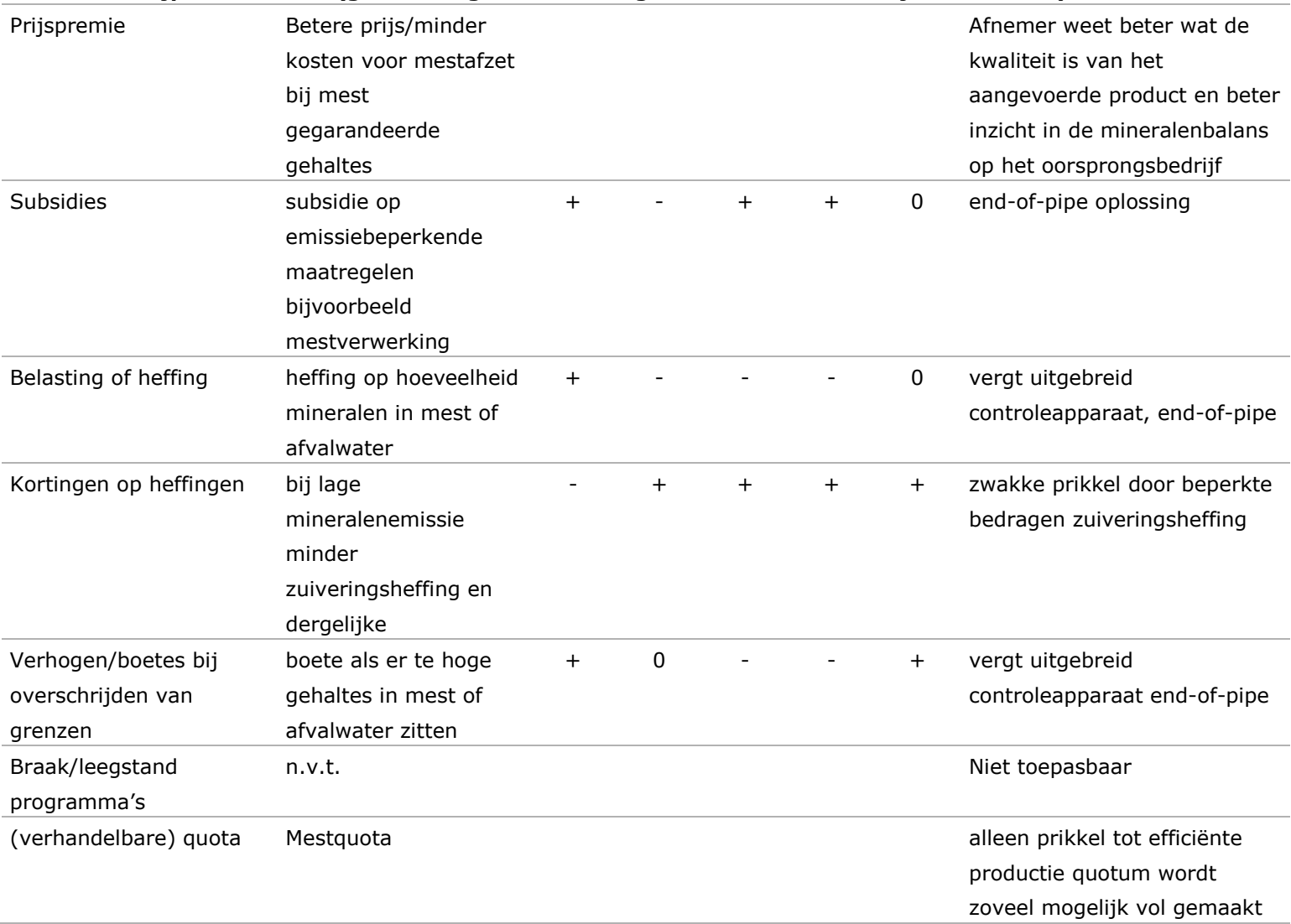


Tabel B1.2

Beoordeling van mogelijke nieuwe financiële instrumenten om emissies van gewasbeschermingsmiddelen te reduceren aan de hand van de vijf beoordelingscriteria

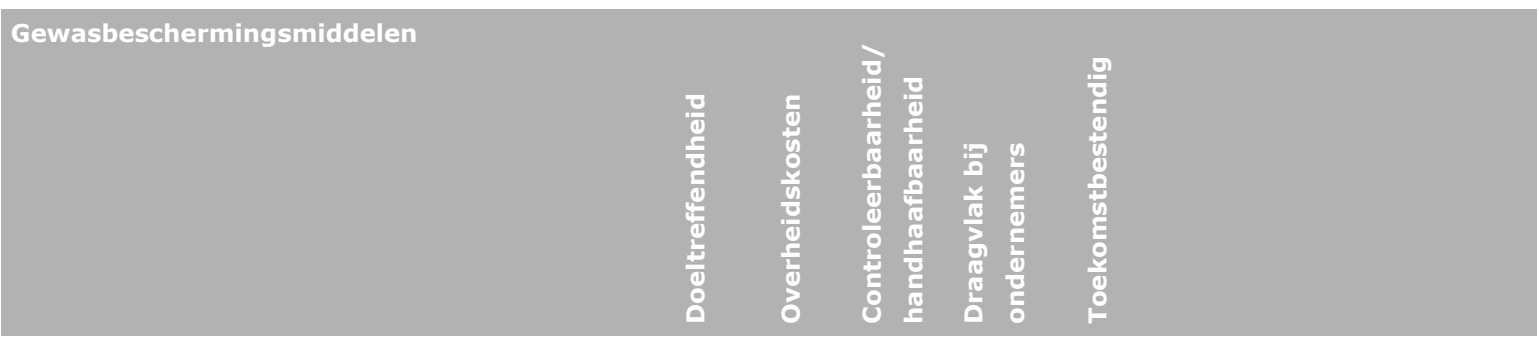

Aanvoer

Instrumen

\section{Omschrijving}

Opmerkingen

Prijspremie

goedkoper maken van

alternatieven bijv. natuurlijke

gewasbeschermingsmiddelen

Alleen doeltreffend als

alternatief minstens zo

effectief is. Alleen draagvlak

bij leveranciers als

overheid/collectief betaalt, bijvoorbeeld uit heffingen

Subsidies subsidie op laag-risico stoffen $+-_{-}++_{+}+$Draagt bij aan het principe

'vervuiler betaalt', als

gebruiker de subsidie

terugziet op zijn factuur

Belasting of

heffing belasting bij

producent/importeur op

hoog-risico stoffen,

resulterend in hogere

aankoopprijs voor de teler
$0 \quad$ Meer draagvlak bij

ondernemers als opbrengsten hiervan gebruikt kunnen worden voor subsidies. Draagt bij aan principe 'vervuiler betaalt', als gebruiker de heffing terugziet op zijn factuur.

\begin{tabular}{|c|c|c|c|c|c|c|c|}
\hline $\begin{array}{l}\text { Kortingen op } \\
\text { heffingen }\end{array}$ & $\begin{array}{l}\text { Lagere heffing bij } \\
\text { producent/importeur op laag- } \\
\text { risico stoffen, }\end{array}$ & + & - & + & + & + & $\begin{array}{l}\text { resulterend in lagere } \\
\text { aankoopprijs voor de teler }\end{array}$ \\
\hline $\begin{array}{l}\text { Verhogen/boetes } \\
\text { bij overschrijden } \\
\text { van grenzen }\end{array}$ & n.v.t. & & & & & & $\begin{array}{l}\text { bestaat al in de vorm van } \\
\text { intrekken van toelating, als } \\
\text { een middel structureel tot } \\
\text { normoverschrijdingen in } \\
\text { oppervlaktewater leidt }\end{array}$ \\
\hline $\begin{array}{l}\text { Braak/leegstand } \\
\text { programma's }\end{array}$ & n.v.t. & & & & & & $\begin{array}{l}\text { bestaat al in de vorm van } \\
\text { verplichting tot opstelling van } \\
\text { Emissie-Reductie-Plan, als } \\
\text { een middel structureel tot } \\
\text { normoverschrijdingen in } \\
\text { oppervlaktewater leidt }\end{array}$ \\
\hline $\begin{array}{l}\text { (verhandelbare) } \\
\text { quota }\end{array}$ & n.v.t. & & & & & & $\begin{array}{l}\text { Zit impliciet ingebakken in } \\
\text { Emissie-Reductie-Plannen. } \\
\text { Restricties op middel A geven } \\
\text { ruimte voor middel B }\end{array}$ \\
\hline \multicolumn{8}{|l|}{ Bedrijf } \\
\hline Prijspremie & nvt & & & & & & Niet toepasbaar \\
\hline Subsidies & $\begin{array}{l}\text { subsidie op maatregelen die } \\
\text { middelengebruik verminderen }\end{array}$ & + & - & + & + & + & bijvoorbeeld: Wings sprayer \\
\hline $\begin{array}{l}\text { Belasting of } \\
\text { heffing }\end{array}$ & $\begin{array}{l}\text { heffing bij aankoop } \\
\text { gewasbeschermingsmiddelen }\end{array}$ & 0 & + & + & - & - & $\begin{array}{l}\text { gebruiker kijkt bij aankoop } \\
\text { naar noodzaak van } \\
\text { bespuiting, de prijs van het } \\
\text { middel speelt dan geen grote } \\
\text { rol }\end{array}$ \\
\hline $\begin{array}{l}\text { Kortingen op } \\
\text { heffingen }\end{array}$ & $\begin{array}{l}\text { Lagere heffing op laag-risico } \\
\text { stoffen }\end{array}$ & + & - & + & + & + & Zit dicht bij subsidie \\
\hline
\end{tabular}




\begin{tabular}{|c|c|c|c|c|c|c|c|}
\hline $\begin{array}{l}\text { Verhogen/boetes } \\
\text { bij overschrijden } \\
\text { van grenzen }\end{array}$ & n.v.t. & + & + & - & - & - & $\begin{array}{l}\text { bestaat al in de vorm van } \\
\text { verdwijnen van toelating, als } \\
\text { een middel structureel tot } \\
\text { normoverschrijdingen in } \\
\text { oppervlaktewater leidt }\end{array}$ \\
\hline $\begin{array}{l}\text { Braak/leegstand } \\
\text { programma's }\end{array}$ & vergoeding FAB-stroken & 0 & - & - & 0 & - & \\
\hline Verzekeringen & $\begin{array}{l}\text { Verzekering van gewasschade } \\
\text { door ernstige ziekte/plaag- } \\
\text { uitbraken }\end{array}$ & + & - & + & - & - & vgl. brede weersverzekering \\
\hline $\begin{array}{l}\text { Verhandelbare } \\
\text { quota }\end{array}$ & $\begin{array}{l}\text { Bedrijven met hoge } \\
\text { milieubelasting moeten } \\
\text { heffing betalen aan collectief } \\
\text { fonds voor onderzoek/ } \\
\text { innovatie (vgl. } \mathrm{CO}_{2} \text {-sector- }\end{array}$ & + & + & - & - & - & $\begin{array}{l}\text { veronderstelt } \\
\text { middelenregistratie; is eerder } \\
\text { gestrand op administratieve } \\
\text { lastendruk; stimuleert } \\
\text { innovatie }\end{array}$ \\
\hline
\end{tabular}

\section{Afvoer van hoofdproduct}

\begin{tabular}{|c|c|c|c|c|c|c|c|}
\hline Prijspremie & $\begin{array}{l}\text { hogere prijs voor leveren uit } \\
\text { productie met gebruik van } \\
\text { natuurlijke } \\
\text { gewasbeschermingsmiddelen; } \\
\text { nieuwe productconcepten (vgl } \\
\text { Tasty Tom en dergelijke) }\end{array}$ & + & + & + & + & + & $\begin{array}{l}\text { mogelijkheid om extra kosten } \\
\text { uit de markt terug te halen, } \\
\text { werkt alleen bij voorsprong } \\
\text { op concurrentie; draagvlak } \\
\text { gunstig bij marktgerichte } \\
\text { ondernemers }\end{array}$ \\
\hline Subsidies & $\begin{array}{l}\text { subsidie bij bewezen laag } \\
\text { middelengebruik }\end{array}$ & + & - & - & + & - & $\begin{array}{l}\text { veronderstelt } \\
\text { middelenregistratie, is eerder } \\
\text { gestrand op administratieve } \\
\text { lastendruk }\end{array}$ \\
\hline $\begin{array}{l}\text { Belasting of } \\
\text { heffing }\end{array}$ & n.v.t. & & & & & & $\begin{array}{l}\text { Ondermijnt gelijk speelveld in } \\
\text { Europa }\end{array}$ \\
\hline $\begin{array}{l}\text { Kortingen op } \\
\text { heffingen }\end{array}$ & n.v.t. & & & & & & $\begin{array}{l}\text { Doet denken aan } \\
\text { rondpompen van geld }\end{array}$ \\
\hline $\begin{array}{l}\text { Verhogen/boetes } \\
\text { bij overschrijden } \\
\text { van grenzen }\end{array}$ & n.v.t. & & & & & & $\begin{array}{l}\text { bestaat al in de vorm van } \\
\text { afkeuren van geleverd } \\
\text { product door afnemers bij } \\
\text { overschrijding van MRL- } \\
\text { normen }\end{array}$ \\
\hline $\begin{array}{l}\text { Braak/leegstand } \\
\text { programma's }\end{array}$ & n.v.t. & & & & & & Geldt alleen voor productie \\
\hline $\begin{array}{l}\text { (Verhandelbare) } \\
\text { quota }\end{array}$ & n.v.t. & & & & & & $\begin{array}{l}\text { Werkt in dit stadium erg } \\
\text { indirect en is ingewikkeld } \\
\text { vanwege grote diversiteit in } \\
\text { plantaardige producten }\end{array}$ \\
\hline $\begin{array}{l}\text { Verhandelbare } \\
\text { quota }\end{array}$ & $\begin{array}{l}\text { Productiequotum bij } \\
\text { suikerbieten }\end{array}$ & 0 & 0 & + & - & - & $\begin{array}{l}\text { indirecte maatregel; leidt tot } \\
\text { substitutie in gewassenpakket }\end{array}$ \\
\hline
\end{tabular}

\section{Afvoer van bijproduct/afval}

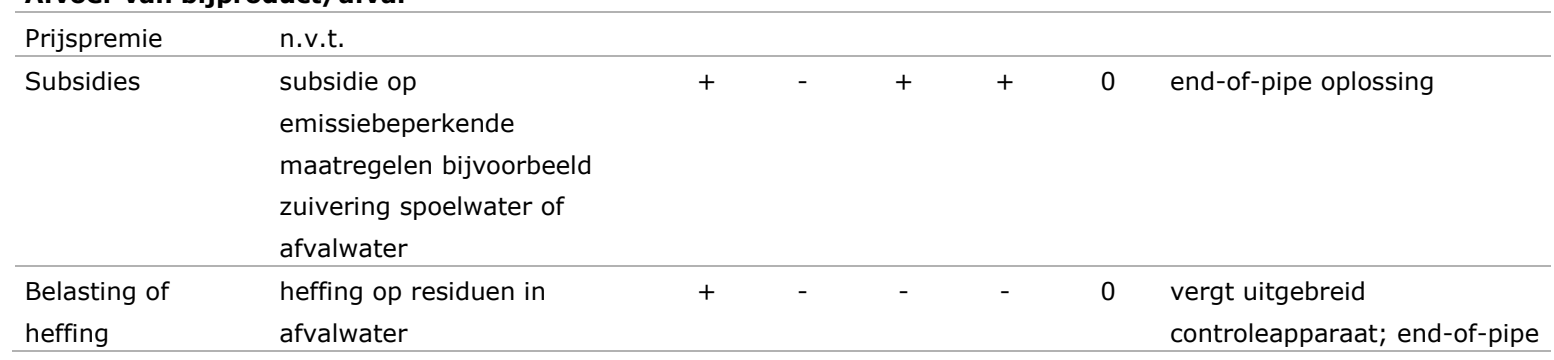




\begin{tabular}{|c|c|c|c|c|c|c|c|}
\hline Gewasbescherm & Igsmiddelen & 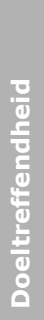 & $\begin{array}{l}\frac{5}{0} \\
\frac{1}{6} \\
0 \\
\frac{0}{0} \\
\frac{0}{0} \\
\frac{0}{10} \\
\frac{2}{2} \\
0 \\
0\end{array}$ & 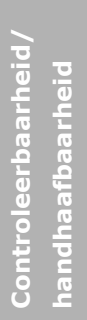 & 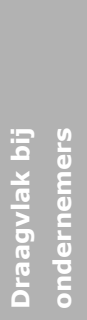 & 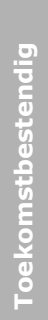 & \\
\hline $\begin{array}{l}\text { Kortingen op } \\
\text { heffingen }\end{array}$ & $\begin{array}{l}\text { bij lage emissie via afvalwater } \\
\text { minder zuiveringsheffing en } \\
\text { dergelijke }\end{array}$ & - & + & + & + & + & $\begin{array}{l}\text { zwakke prikkel door beperkte } \\
\text { bedragen zuiveringsheffing }\end{array}$ \\
\hline $\begin{array}{l}\text { Verhogen/boetes } \\
\text { bij overschrijden } \\
\text { van grenzen }\end{array}$ & $\begin{array}{l}\text { boete als er te veel residuen } \\
\text { in afvalwater zitten }\end{array}$ & + & 0 & - & - & + & $\begin{array}{l}\text { vergt uitgebreid } \\
\text { controleapparaat; end-of-pipe }\end{array}$ \\
\hline Verzekeringen & n.v.t. & & & & & & $\begin{array}{l}\text { Dan ga je milieurisico's } \\
\text { verzekeren die samenleving } \\
\text { helemaal niet wil lopen }\end{array}$ \\
\hline
\end{tabular}


Tabel B1.3

Beoordeling van mogelijke nieuwe financiële instrumenten om emissies van diergeneesmiddelen te reduceren aan de hand van de vijf beoordelingscriteria

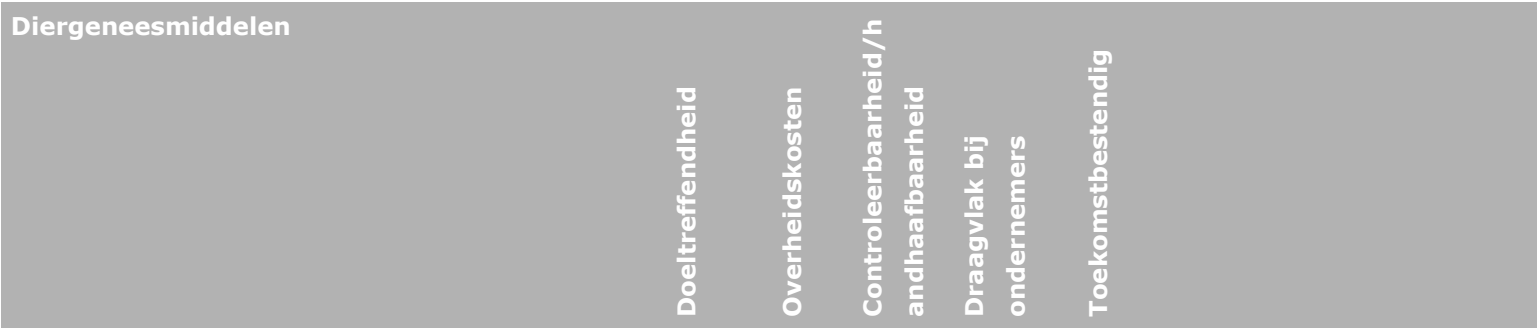

\begin{tabular}{|c|c|c|c|c|c|c|c|}
\hline instrument & Omschrijving & & & & & & Opm. \\
\hline Prijspremie & $\begin{array}{l}\text { goedkoper maken van } \\
\text { alternatieven bijv. probiotica } \\
\text { of speciale voeders }\end{array}$ & - & + & + & + & + & Hoge kosten voor sector \\
\hline Subsidies & $\begin{array}{l}\text { subsidie op het ontwikkelen } \\
\text { van alternatieven voor } \\
\text { antibiotica }\end{array}$ & + & - & + & + & + & $\begin{array}{l}\text { draagt het ook bij aan } \\
\text { principe 'vervuiler betaalt'? }\end{array}$ \\
\hline $\begin{array}{l}\text { Belasting of } \\
\text { heffing }\end{array}$ & $\begin{array}{l}\text { belasting bij } \\
\text { producent/importeur op } \\
\text { antibiotica, }\end{array}$ & 0 & + & + & - & 0 & $\begin{array}{l}\text { resulterend in hogere } \\
\text { aankoopprijs voor de } \\
\text { veehouder }\end{array}$ \\
\hline $\begin{array}{l}\text { Kortingen op } \\
\text { heffingen }\end{array}$ & n.v.t. & & & & & & Zie vorige \\
\hline $\begin{array}{l}\text { Braak/leegstand } \\
\text { programma's }\end{array}$ & n.v.t. & & & & & & Niet toepasbaar \\
\hline $\begin{array}{l}\text { (verhandelbare) } \\
\text { Quota }\end{array}$ & n.v.t. & & & & & & Niet toepasbaar \\
\hline Bedrijf & & & & & & & \\
\hline Prijspremie & n.v.t. & & & & & & Niet toepasbaar \\
\hline Subsidies & $\begin{array}{l}\text { subsidie op maatregelen die } \\
\text { gebruik verminderen }\end{array}$ & + & - & + & + & + & $\begin{array}{l}\text { Wordt bijvoorbeeld toegepast } \\
\text { bij VAMIL regeling }\end{array}$ \\
\hline $\begin{array}{l}\text { Verhogen/boetes } \\
\text { bij overschrijden } \\
\text { van grenzen }\end{array}$ & $\begin{array}{l}\text { boete bij overschrijden } \\
\text { streefwaarde } \\
\text { antibioticagebruik }\end{array}$ & + & + & 0 & - & + & $\begin{array}{l}\text { centrale registratie is er al; } \\
\text { illegale import is lastig te } \\
\text { controleren }\end{array}$ \\
\hline $\begin{array}{l}\text { Braak/leegstand } \\
\text { programma's }\end{array}$ & $\begin{array}{l}\text { leegstand bij naderende } \\
\text { overschrijding streefwaarde } \\
\text { antibiotica }\end{array}$ & + & + & - & - & - & $\begin{array}{l}\text { dure maatregel voor de } \\
\text { bedrijven }\end{array}$ \\
\hline $\begin{array}{l}\text { Verhandelbare } \\
\text { quota }\end{array}$ & $\begin{array}{l}\text { Bijvoorbeeld antibiotica- } \\
\text { gebruiksrechten }\end{array}$ & + & + & - & - & - & $\begin{array}{l}\text { centrale registratie is er al; } \\
\text { draagvlak afhankelijk van } \\
\text { efficiëntie; remt innovatie }\end{array}$ \\
\hline \multicolumn{8}{|c|}{ Afvoer van hoofdproduct } \\
\hline Prijspremie & $\begin{array}{l}\text { hogere prijs voor leveren uit } \\
\text { antibioticavrije productie }\end{array}$ & + & + & + & + & + & $\begin{array}{l}\text { onvoldoende mogelijkheid om } \\
\text { extra kosten uit de markt } \\
\text { terug te halen }\end{array}$ \\
\hline Subsidies & $\begin{array}{l}\text { subsidie bij bewezen laag } \\
\text { antibioticagebruik }\end{array}$ & + & - & + & + & + & \\
\hline $\begin{array}{l}\text { Belasting of } \\
\text { heffing }\end{array}$ & n.v.t. & & & & & & Niet toepasbaar \\
\hline
\end{tabular}




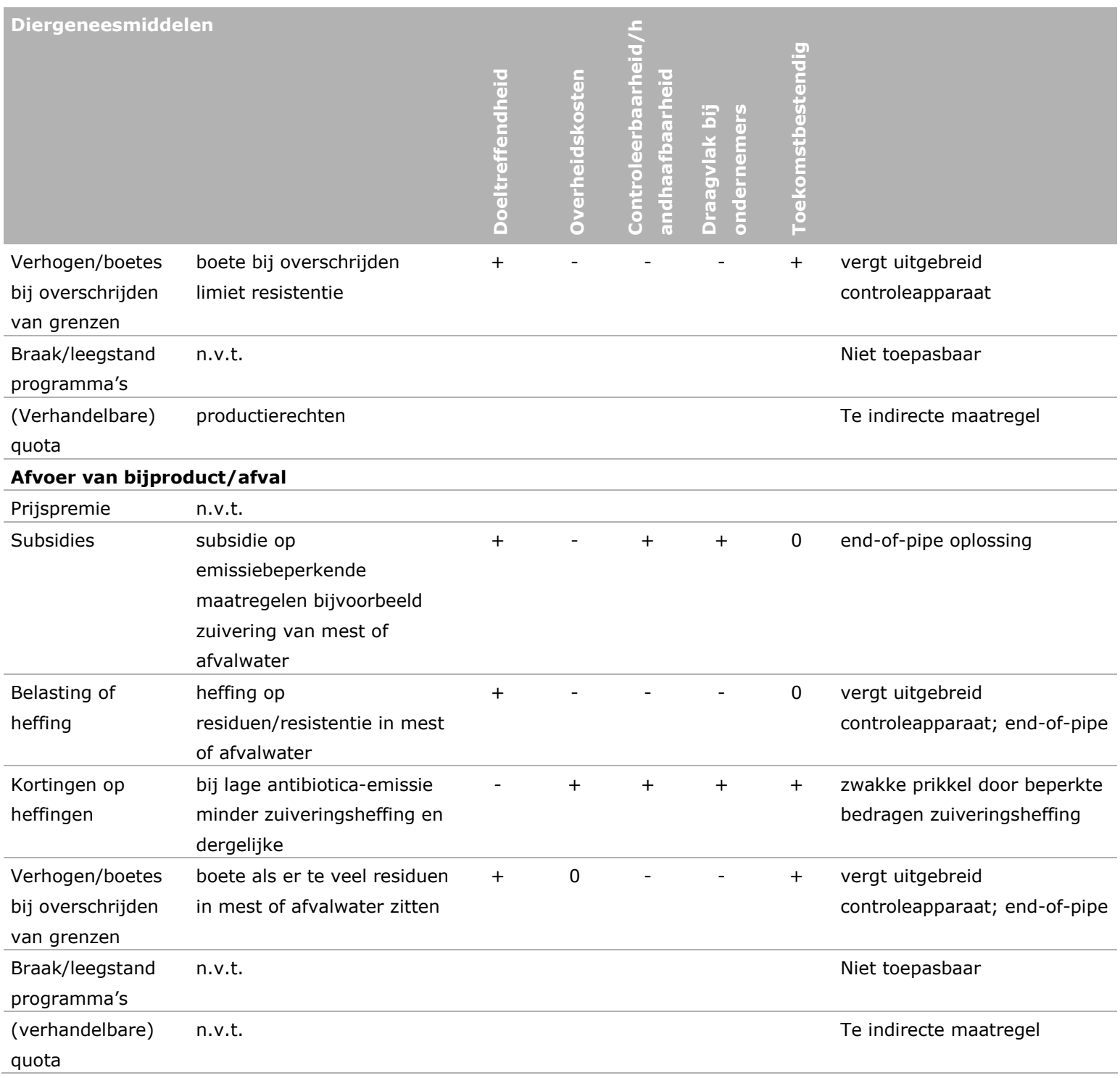


Tabel B1.4

Beoordeling van mogelijke nieuwe financiële instrumenten om emissies van zware metalen te reduceren aan de hand van de vijf beoordelingscriteria

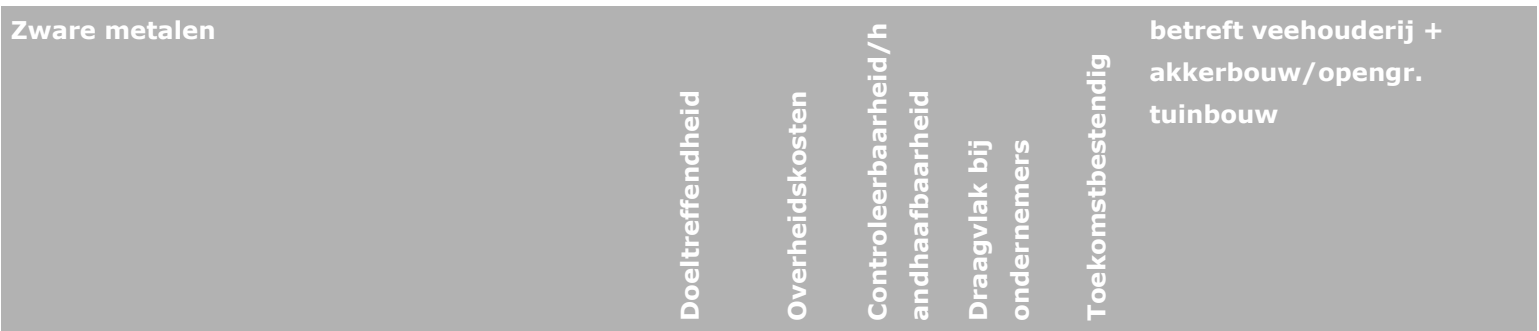

Aanvoer

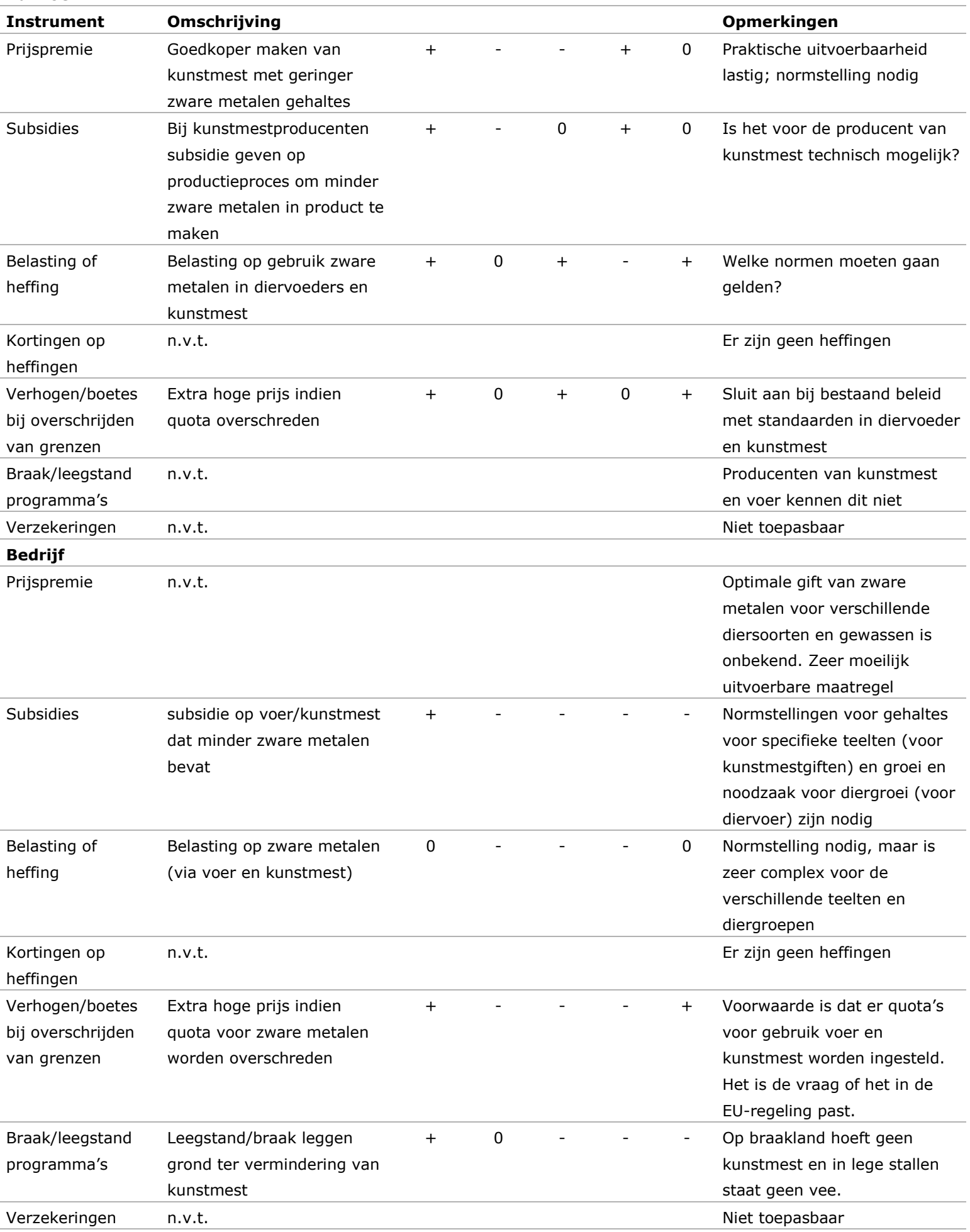


Afvoer van hoofdproduct

\begin{tabular}{|c|c|c|c|c|c|c|c|}
\hline Prijspremie & $\begin{array}{l}\text { Dieren of gewassen met } \\
\text { minder zware metalen } \\
\text { worden tegen een betere } \\
\text { prijs in de markt gezet. }\end{array}$ & + & 0 & - & - & - & $\begin{array}{l}\text { Minder zware metalen leidt } \\
\text { soms tot slechtere kwaliteit } \\
\text { van gewassen en dieren. } \\
\text { Tegengesteld effect voor de } \\
\text { prijs waarschijnlijk }\end{array}$ \\
\hline Subsidies & $\begin{array}{l}\text { Subsidie op producten } \\
\text { (gewasopbrengsten of } \\
\text { dieren) die met een goede } \\
\text { balans van zware metalen } \\
\text { zijn geproduceerd. }\end{array}$ & 0 & - & - & + & - & $\begin{array}{l}\text { Vereist een uitgebreide } \\
\text { administratie en controle }\end{array}$ \\
\hline $\begin{array}{l}\text { Belasting of } \\
\text { heffing }\end{array}$ & $\begin{array}{l}\text { Belastingen of heffingen op } \\
\text { product }\end{array}$ & 0 & + & - & - & - & $\begin{array}{l}\text { Meer zware metalen leidt } \\
\text { soms tot een beter product en } \\
\text { is dus niet per definitie slecht. }\end{array}$ \\
\hline $\begin{array}{l}\text { Verhogen/boetes } \\
\text { bij overschrijden } \\
\text { van grenzen }\end{array}$ & $\begin{array}{l}\text { Boete als er te veel of te } \\
\text { weinig zware metalen in het } \\
\text { voedsel zitten. }\end{array}$ & + & - & 0 & 0 & + & $\begin{array}{l}\text { Ter garantie van de kwaliteit } \\
\text { van voedselproducten is het } \\
\text { de voorwaarde dat er een } \\
\text { range voor zware metalen in } \\
\text { het product moet worden } \\
\text { ingesteld. }\end{array}$ \\
\hline $\begin{array}{l}\text { Braak/leegstanc } \\
\text { programma's }\end{array}$ & n.v.t. & + & 0 & - & 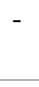 & - & Speelt alleen op bedrijfsniveau \\
\hline Belasting of heffing & $\begin{array}{l}\text { Heffing op zware metalen in } \\
\text { mest }\end{array}$ & + & 0 & - & - & - & $\begin{array}{l}\text { Meten van zware metalen in } \\
\text { mest. Meeliften met } \\
\text { nutriënten. Normstelling } \\
\text { nodig. }\end{array}$ \\
\hline $\begin{array}{l}\text { Kortingen op } \\
\text { heffingen }\end{array}$ & n.v.t. & & & & & & Er zijn nu geen heffingen. \\
\hline $\begin{array}{l}\text { Verhogen/boetes } \\
\text { bij overschrijden } \\
\text { van grenzen }\end{array}$ & $\begin{array}{l}\text { Boete als er te veel zware } \\
\text { metalen in de mest zit. }\end{array}$ & + & - & - & - & 0 & $\begin{array}{l}\text { Het is een voorwaarde dat er } \\
\text { een norm voor zware metalen } \\
\text { in de mest moet worden } \\
\text { ingesteld. }\end{array}$ \\
\hline
\end{tabular}




\section{Gewasbeschermingsmiddelen}

Het verkoopgedrag van de middelenhandel zou kunnen worden bijgestuurd door hen (net als hypotheekadviseurs) te verplichten om advieskosten apart af te rekenen en provisies op omzet te verbieden. De kwaliteit van de advisering kan verder worden verbeterd door adviseurs te certificeren.

\section{Tabel B1.5}

Aanvullende instrumenten gewasbeschermingsmiddelen

\begin{tabular}{|c|c|c|c|c|c|c|}
\hline Schakel/Instrument & Doel & \multicolumn{5}{|c|}{ Criteriumbeoordeling } \\
\hline \multicolumn{7}{|l|}{ Middelenhandel } \\
\hline Afschaffen provisie op omzet & Stop perverse prikkels & 0 & - & + & 0 & + \\
\hline Certificatie van adviseurs & Toegang tot adviesmarkt & 0 & - & + & + & 0 \\
\hline
\end{tabular}

Toelichting: DT=Doeltreffendheid; OK=Overheidskosten; $C O=$ Controleerbaarheid; $D R=$ Draagvlak ondernemers; TB=Toekomstbestendigheid

\section{Diergeneesmiddelen}

De kwaliteit van het (dagelijks) management is de sleutel tot een betere diergezondheid en lager medicijngebruik. Voor een verdere vermindering van diergeneesmiddelengebruik is vooral meer aandacht voor preventieve diergezondheidszorg nodig. Bokma-Bakker en Bergevoet (2011) noemen drie redenen waarom nog niet alle bedrijven erin geslaagd zijn om het diergezondheidsmanagement sterk te verbeteren:

a. te weinig druk om te veranderen

b. kennisoverdracht in het veld is onvoldoende

c. huidige kengetallen hebben te weinig relatie met diergezondheidsproblemen en de mogelijkheden tot aanpak daarvan.

\section{Tabel B1.6}

Aanvullende instrumenten diergeneesmiddelen

\begin{tabular}{|c|c|c|c|c|c|c|}
\hline Instrument & Doel & DT & OK & CO & DR & TB \\
\hline $\begin{array}{l}\text { Private certificering waarin meer kritieke } \\
\text { middelen uitgebannen worden }\end{array}$ & Beperken toelating van kritieke middelen & + & + & + & 0 & + \\
\hline
\end{tabular}

Toelichting: DT=Doeltreffendheid; $\mathrm{OK}=$ Overheidskosten; $\mathrm{CO}=$ Controleerbaarheid; $\mathrm{DR}=$ Draagvlak ondernemers; $\mathrm{TB}=$ Toekomstbestendigheid

Het gebruik van bedrijfsgezondheidsplannen zou versterkt kunnen worden door te zorgen voor heldere doelstellingen, niet alleen voor antibioticagebruik (die zijn er al), maar ook voor diergezondheid. Per doelstelling zouden een of enkele bruikbare kengetallen gedefinieerd kunnen worden, die de veehouder ondersteunen in het bedrijfsmanagement. Deze doelstellingen zouden in eerste instantie op sectorniveau gedefinieerd kunnen worden en vervolgens vertaald naar individuele bedrijfsdoelstellingen. Dit kan worden bevorderd door hieraan nadrukkelijker aandacht te besteden in private kwaliteitssystemen, bijvoorbeeld bij de certificering van de geborgde dierenarts.

\footnotetext{
${ }^{10}$ Waarschijnlijk vereist dit instrument een behoorlijke inspanning van de belanghebbenden, zowel de veehouder als de adviseurs. Als dit onderdeel wordt van kwaliteitsprogramma's (bijvoorbeeld geborgde dierenarts) dan leidt het mogelijk tot hogere certificeringskosten, met name voor de ondernemers die niet aan de eisen voldoen.

${ }^{11}$ De indruk bestaat dat de bedrijfsgezondheidsplannen momenteel nog niet erg intensief gebruikt worden. Waarschijnlijk heeft dit te maken met de daarbij behorende extra kosten voor de dierenarts en mogelijk met praktische uitvoerbaarheid (veehouders houden niet van papieren plannen).
} 
Tabel B1.7

Hoe het RESET-model gebruikt kan worden voor nieuw beleid voor zware metalen

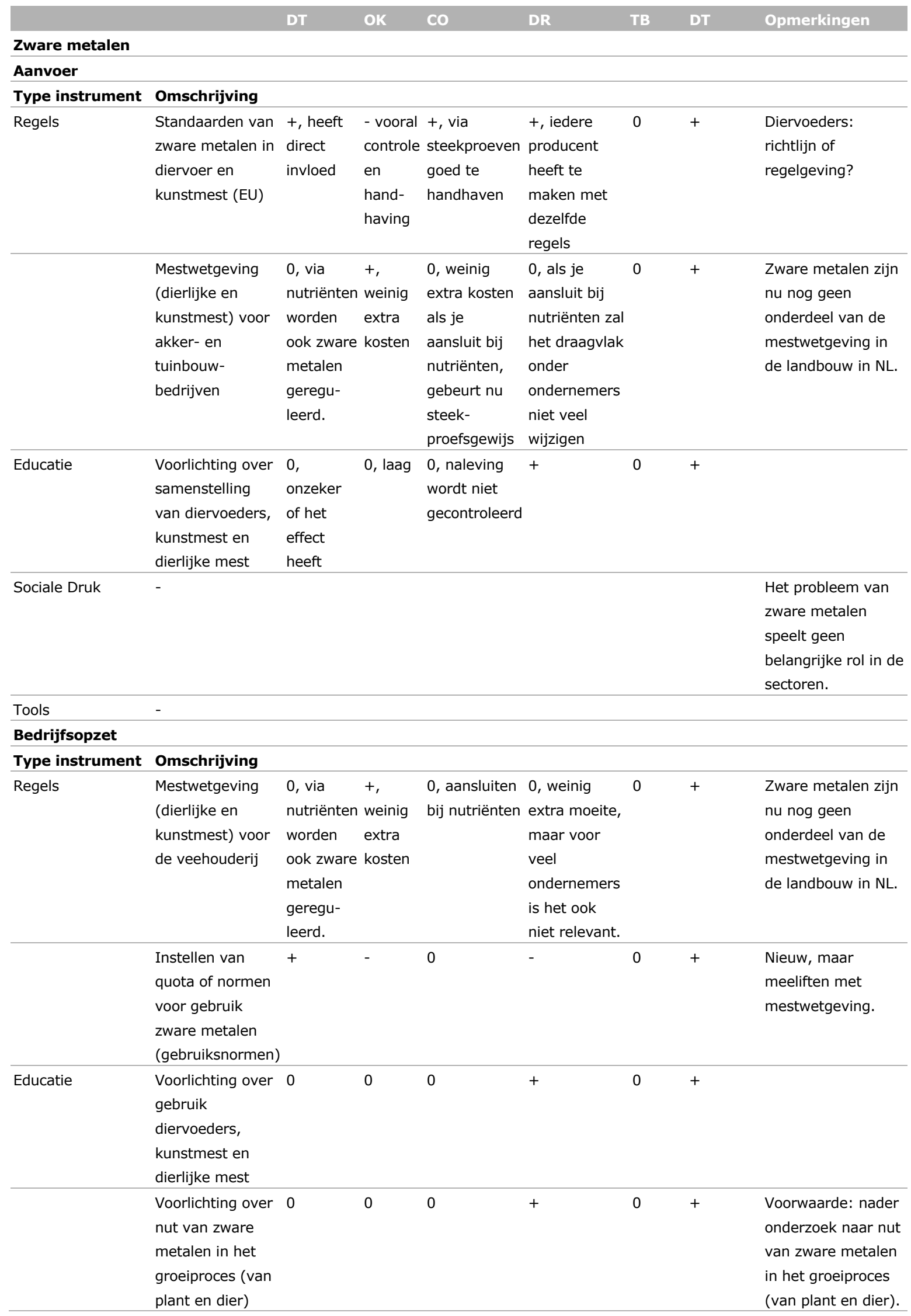




\begin{tabular}{|c|c|c|c|c|c|c|c|c|}
\hline & & DT & OK & $\mathrm{CO}$ & DR & TB & DT & Opmerkingen \\
\hline Sociale Druk & $\begin{array}{l}\text { Praktijknetwerk } \\
\text { bij schadelijke } \\
\text { effecten van } \\
\text { zware metalen }\end{array}$ & $\begin{array}{l}0, \text { geen } \\
\text { direct } \\
\text { effect en } \\
\text { effect is } \\
\text { onzeker }\end{array}$ & & & & & & $\begin{array}{l}\text { Kan regionaal } \\
\text { worden ingezet (op } \\
\text { locaties waar zware } \\
\text { metalen uit de } \\
\text { landbouw een } \\
\text { probleem zijn). }\end{array}$ \\
\hline Tools & - & & & & & & & \\
\hline \multicolumn{9}{|c|}{ Afvoer hoofdproduct } \\
\hline Type instrument & Omschrijving & & & & & & & \\
\hline Regels & $\begin{array}{l}\text { Instellen van } \\
\text { quota of normen } \\
\text { voor gebruik } \\
\text { zware metalen } \\
\text { (gebruiks- } \\
\text { normen) }\end{array}$ & + & - & 0 & - & 0 & + & Nieuw \\
\hline \multirow[t]{2}{*}{ Educatie } & $\begin{array}{l}\text { Voorlichting over } \\
\text { te veel (of te } \\
\text { weinig) zware } \\
\text { metalen in } \\
\text { voedsel }\end{array}$ & 0 & 0 & 0 & + & 0 & + & $\begin{array}{l}\text { Optimale } \\
\text { hoeveelheid in } \\
\text { voeding is niet } \\
\text { duidelijk. }\end{array}$ \\
\hline & $\begin{array}{l}\text { Voorlichting over } \\
\text { nut van zware } \\
\text { metalen in het } \\
\text { groeiproces (van } \\
\text { plant en dier) }\end{array}$ & 0 & 0 & 0 & + & 0 & + & $\begin{array}{l}\text { Voorwaarde: nader } \\
\text { onderzoek naar nut } \\
\text { van zware metalen } \\
\text { in het groeiproces } \\
\text { (van plant en dier). }\end{array}$ \\
\hline Sociale Druk & $\begin{array}{l}\text { Praktijknetwerk } \\
\text { bij schadelijke } \\
\text { effecten van } \\
\text { zware metalen }\end{array}$ & $\begin{array}{l}0, \text { geen } \\
\text { direct } \\
\text { effect en } \\
\text { effect is } \\
\text { onzeker }\end{array}$ & & & & & & $\begin{array}{l}\text { Kan regionaal } \\
\text { worden ingezet (op } \\
\text { locaties waar zware } \\
\text { metalen uit de } \\
\text { landbouw een } \\
\text { probleem zijn). }\end{array}$ \\
\hline Tools & - & & & & & & & \\
\hline \multicolumn{9}{|l|}{ Afvoer bijproduct } \\
\hline Type instrument & Omschrijving & & & & & & & \\
\hline \multirow[t]{2}{*}{ Regels } & $\begin{array}{l}\text { Standaarden van } \\
\text { zware metalen in } \\
\text { diervoer en } \\
\text { kunstmest (EU) }\end{array}$ & + & - & + & + & 0 & + & $\begin{array}{l}\text { Diervoeders: } \\
\text { richtlijn of } \\
\text { regelgeving? }\end{array}$ \\
\hline & $\begin{array}{l}\text { Mestwetgeving } \\
\text { (dierlijke en } \\
\text { kunstmest) voor } \\
\text { akker- en } \\
\text { tuinbouw- } \\
\text { bedrijven }\end{array}$ & $\begin{array}{l}0, \text { via } \\
\text { nutriënten } \\
\text { worden } \\
\text { ook zware } \\
\text { metalen } \\
\text { geregu- } \\
\text { leerd. }\end{array}$ & $\begin{array}{l}+, \\
\text { weinig } \\
\text { extra } \\
\text { kosten }\end{array}$ & 0 & 0 & 0 & + & $\begin{array}{l}\text { Zware metalen zijn } \\
\text { nu nog geen } \\
\text { onderdeel van de } \\
\text { mestwetgeving in } \\
\text { de landbouw in NL. }\end{array}$ \\
\hline \multirow[t]{2}{*}{ Educatie } & $\begin{array}{l}\text { Voorlichting over } \\
\text { te veel (of te } \\
\text { weinig?) zware } \\
\text { metalen in } \\
\text { voedsel }\end{array}$ & 0 & 0 & 0 & + & 0 & + & \\
\hline & $\begin{array}{l}\text { Voorlichting over } \\
\text { nut van zware } \\
\text { metalen in het } \\
\text { groeiproces (van } \\
\text { plant en dier) }\end{array}$ & 0 & 0 & 0 & + & 0 & + & $\begin{array}{l}\text { Voorwaarde: nader } \\
\text { onderzoek naar nut } \\
\text { van zware metalen } \\
\text { in het groeiproces } \\
\text { (van plant en dier). }\end{array}$ \\
\hline
\end{tabular}




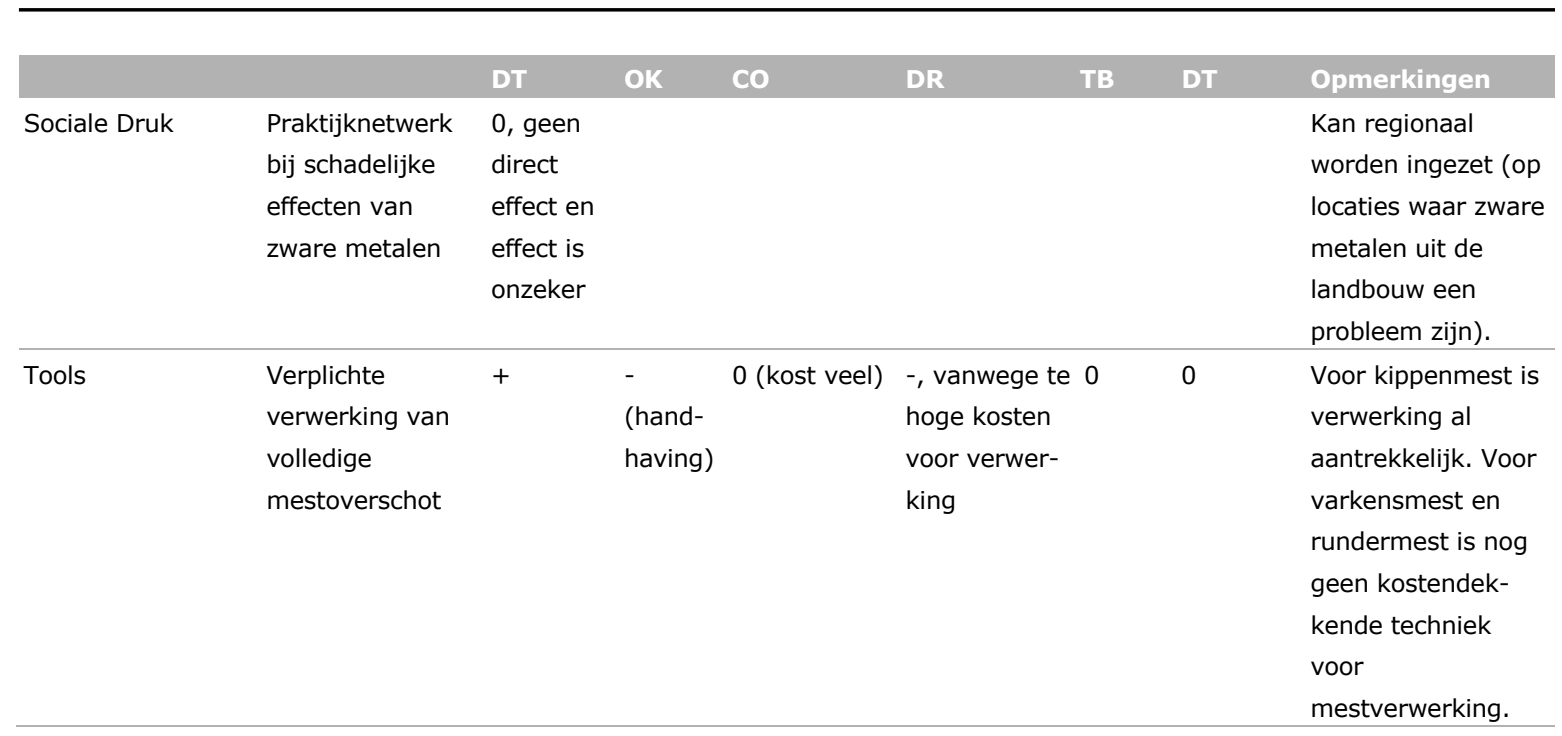




\section{Bijlage 2 Jaarlijkse ophoping van zware metalen in de bodem}

De hoeveelheid organische stof en zware metalen in de bodem van landbouwgrond en bos is tussen 1993 en 2003 niet aantoonbaar veranderd. Waargenomen verschillen vallen binnen de variatie van de meetresultaten. Dit blijkt uit een vergelijking van twee cycli van metingen van het Landelijk Meetnet Bodemkwaliteit (Tabel B2.1).

Tabel B2.1

Jaarlijkse ophoping van zware metalen in de bodem

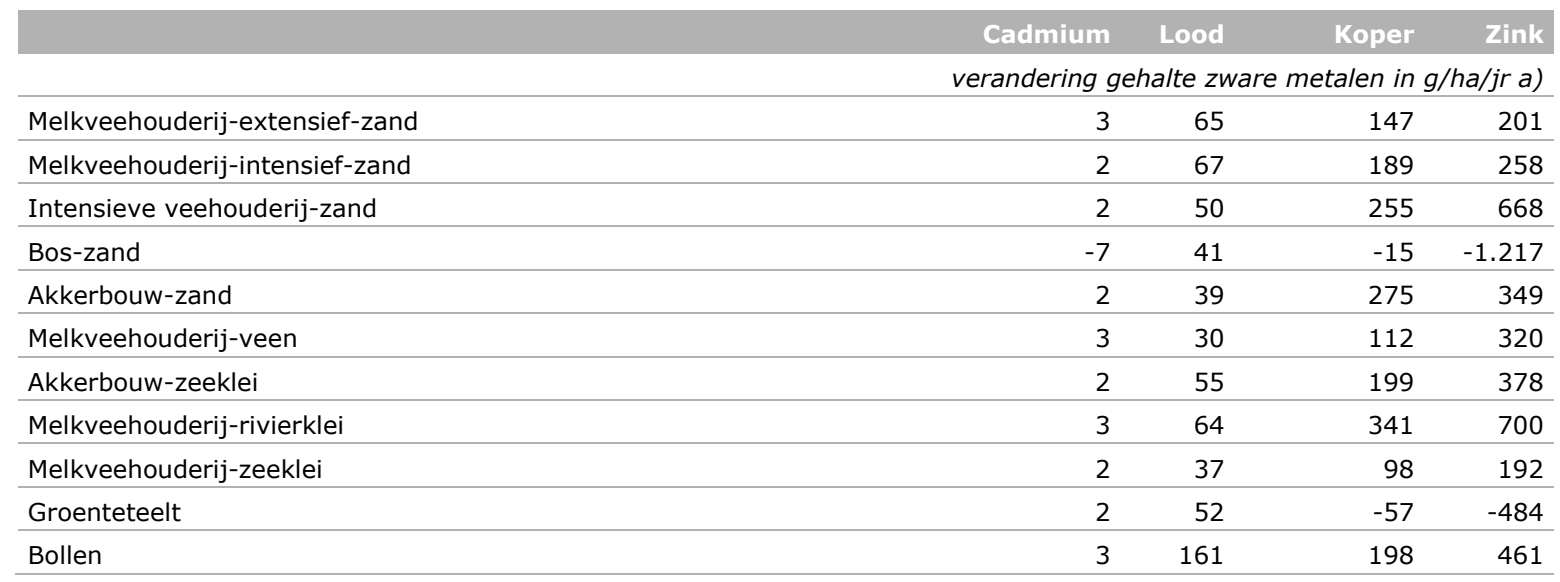

a) De verandering in gehalte is berekend op basis van balansberekeningen. Hierbij is de toevoer van zware metalen via kunstmest, dierlijke

mest, depositie en overige bronnen verminderd met de afvoer via de geoogste gewassen en uitspoeling. De gegevens hebben betrekking op de periode 1993-1997

Bron: Bronswijk et al. (2003) en de daarin beschreven jaarlijkse rapporten (www.clo.nl/026505 PBL/dec13)

De volgende zware metalen zijn nader bekeken: zink, koper, cadmium, lood, chroom, ijzer, nikkel en arseen. In een bepaalde mate zijn zware metalen noodzakelijke sporenelementen die noodzakelijk zijn voor de groei van gewassen en dieren, met name koper en zink. Te weinig zink in het veevoer kan ziekten veroorzaken bij rundvee. Te weinig koper in het voer kan de oorzaak zijn van geringe groei van dieren. Een teveel van deze metalen kan echter leiden tot ophoping en vergiftiging.

Zware metalen in de bodem

Zware metalen komen van nature in de bodem voor. Daarnaast komen zware metalen in landbouwgronden terecht via kunstmest en dierlijke mest en via de lucht. De atmosferische depositie via de lucht is de afgelopen decennia afgenomen door onder andere de invoering van loodvrije benzine en de sanering van de zinkindustrie in Zuid-Nederland. De zware metaalgehalten in veevoer en kunstmest zijn de afgelopen jaren afgenomen (bron: Compendium voor de Leefomgeving). Nationale balansberekeningen laten een daling zien van de nettotoevoer van zware metalen naar landbouwgrond. Het laatste decennium ligt de nettotoevoer op een stabiel niveau. Voor cadmium bedraagt dit circa 1 gram per hectare per jaar, voor koper 200 gram en voor zink 450 gram (hierbij is nog geen rekening gehouden met uitspoeling naar het grondwater). Er zijn het laatste decennium per saldo te weinig zware metalen aan de bodem toegevoegd om dat terug te zien in de bodemanalyses. Landbouwbedrijven op zand en zeeklei hebben in het algemeen lagere gehalten aan zware metalen dan bedrijven op veen, rivierklei en löss. Bij bemonsteringen en toetsing aan de achtergrondwaarden vinden overschrijdingen plaats bij chroom (45\% van de bemonsteringen), cadmium (13\%) en lood (12\%). De interventiewaarden, zoals beschreven in de Circulaire Bodemsanering 2009 (VROM, 2009), worden nergens bereikt. 


\section{Bijlage 3 Regionale verdeling per sector}

De kaarten van de regionale verdeling zijn weergegeven in $\mathrm{k} €$ Standaardopbrengst (SO) per $\mathrm{km}^{2}$ grondoppervlakte, exclusief binnenwater en bebouwde kom. De bedrijfsomvang van een bedrijf wordt gemeten in Standaardopbrengst (SO). Voor elke gewas- en diersoort uit de Landbouwtelling is een SOnorm berekend, die de opbrengsten per eenheid weergeeft die onder normale omstandigheden op jaarbasis behaald worden. De bedrijfsomvang wordt berekend als een sommatie van alle eenheden van de producten maal hun SO-norm. De opbrengsten van toeslagen, subsidies en verbredingsactiviteiten zijn niet meegenomen in de normen en dus ook niet in de totale SO van het bedrijf. De concentratie van agrarische activiteit is weergegeven door per grid (100 x 100 meter: 1 ha) de so te berekenen die binnen een straal van $5 \mathrm{~km}$ van die grid valt. Deze SO wordt uitgedrukt in de grondoppervlakte (ha) van die cirkel.

\section{Akkerbouw}

Ruimtelijke verdeling akkerbouw, 2013

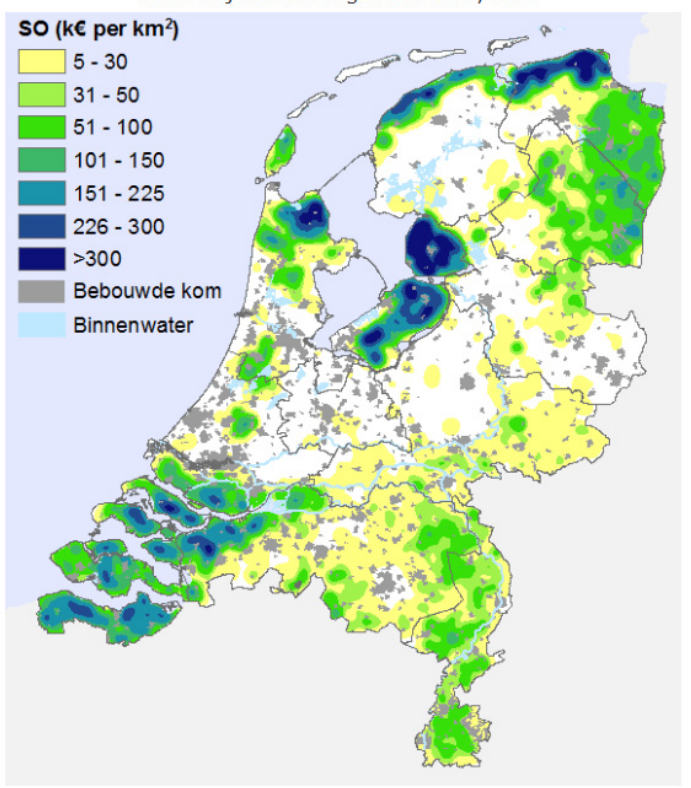

Opengrondgroenteteelt

Ruimtelijke verdeling opengrondsgroenteteelt, 2013

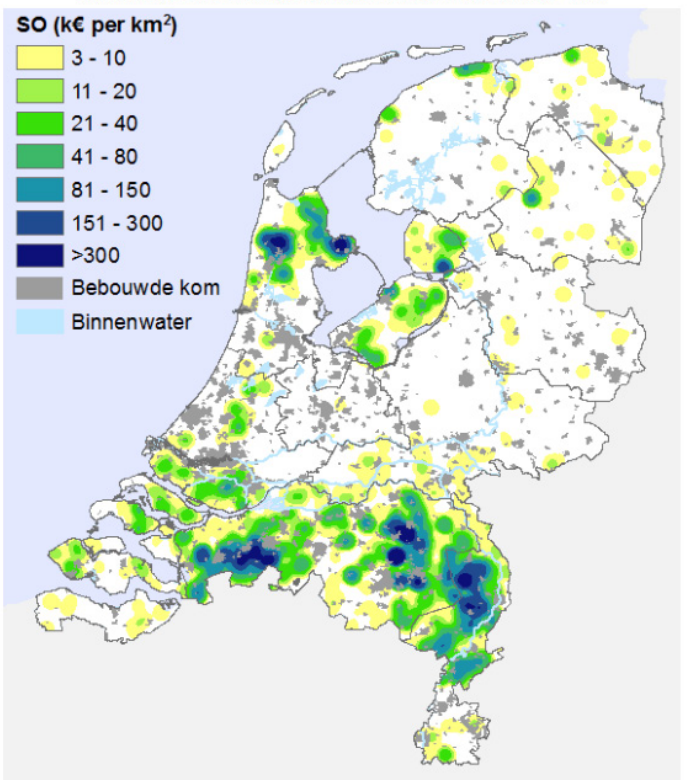

Glastuinbouw

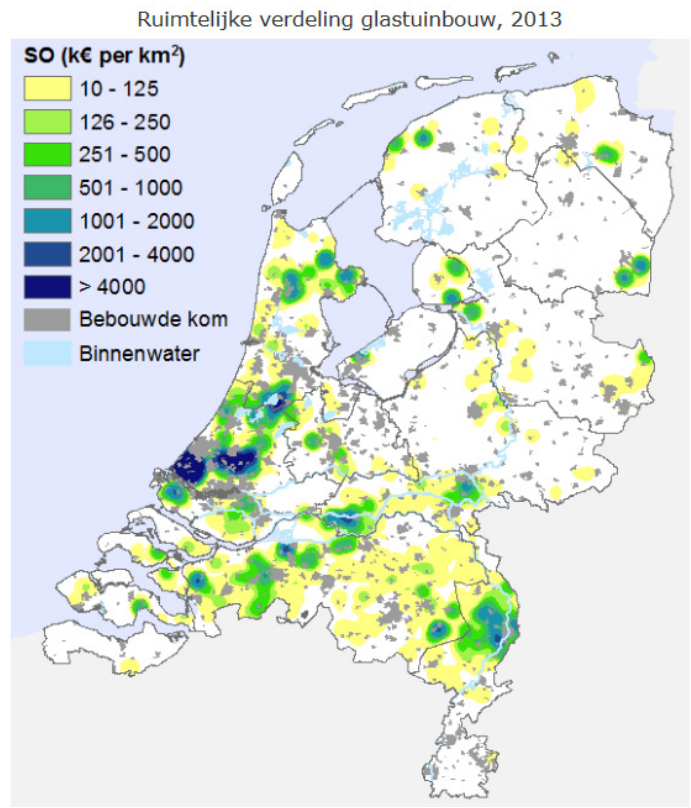

Fruitteelt

Ruimtelijke verdeling fruitteelt, 2013

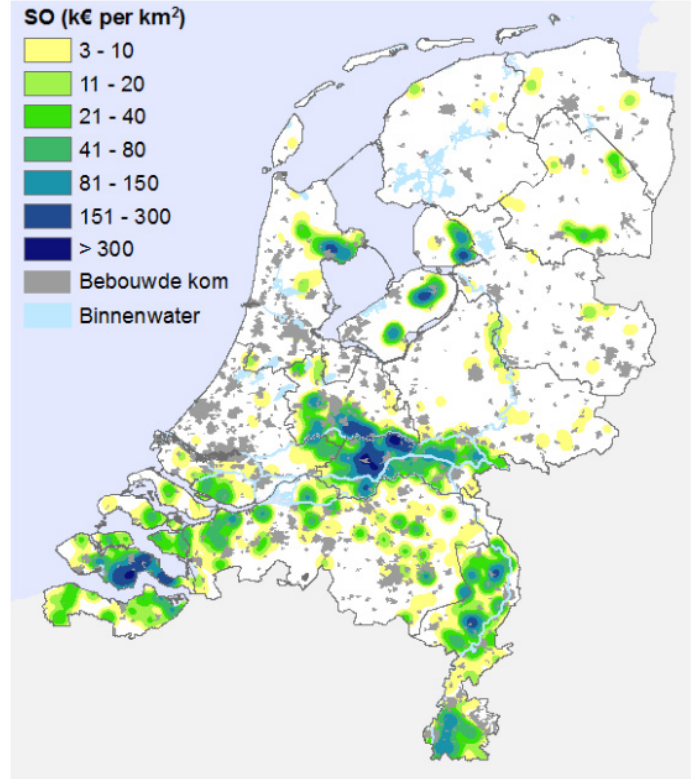




\section{Melkveehouderij}

Ruimtelijke verdeling melkveehouderij, 2013

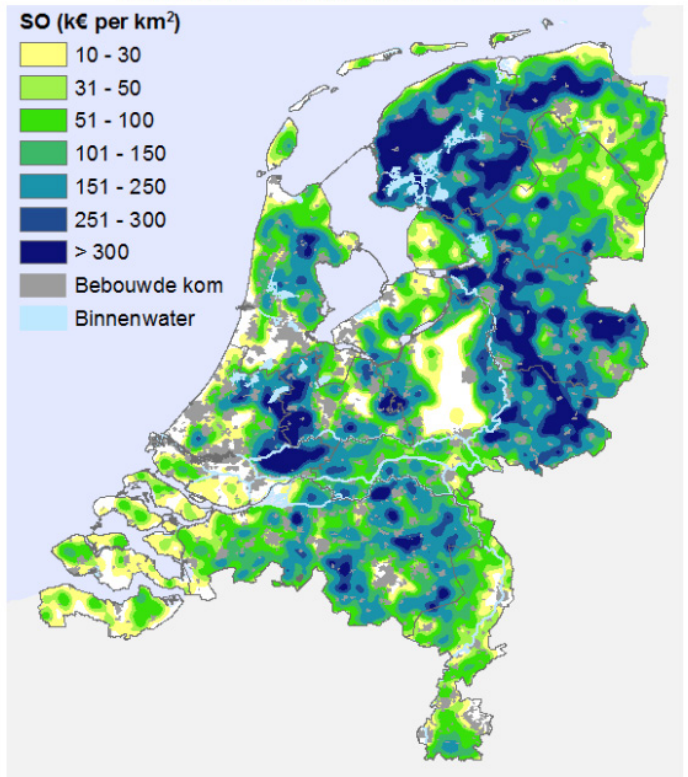

\section{Vleeskalverhouderij}

Ruimtelijke verdeling vleeskalverhouderij, 2013

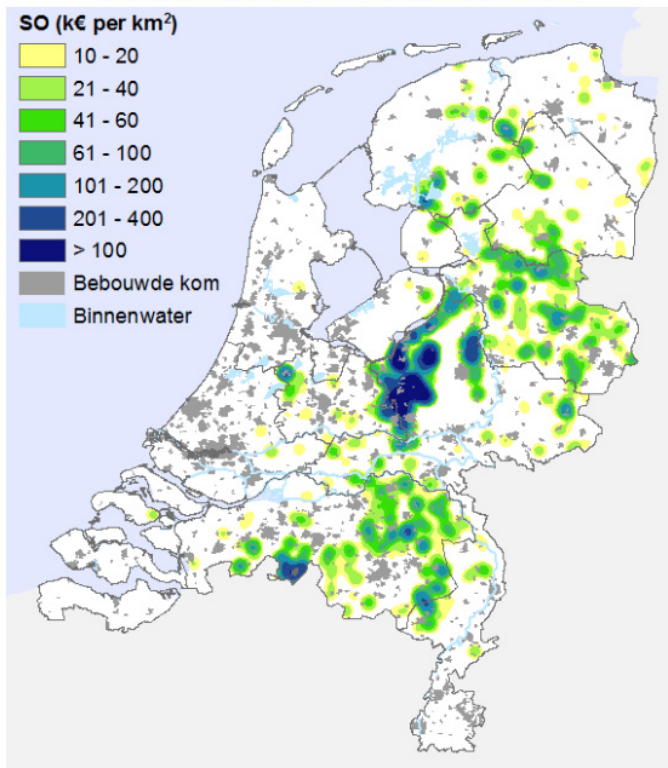

Bron: CBS Landbouwtelling, bewerking LEI Wageningen UR

\section{Varkenshouderij}

Ruimtelijke verdeling varkenshouderij, 2013

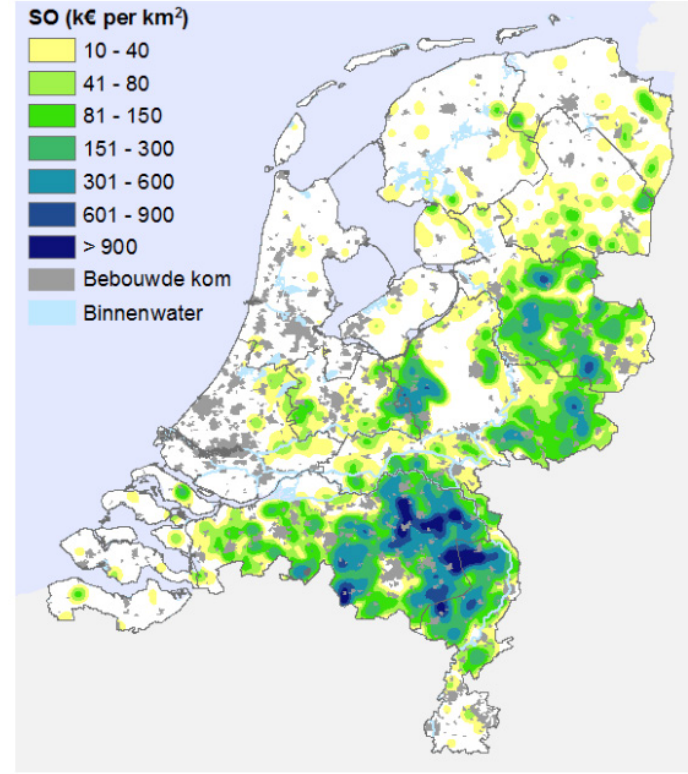

\section{Pluimveehouderij}

Ruimtelijke verdeling pluimveehouderij, 2013

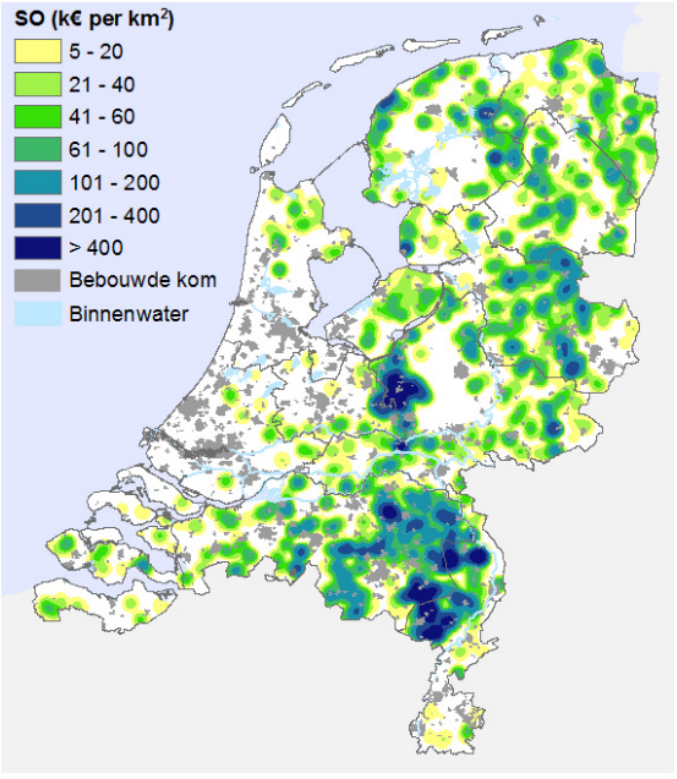




\section{Bijlage 4 Deltaplan agrarisch waterbeheer}

Een concrete uitwerking van mogelijke instrumenten voor toekomstig waterbeheer is te vinden in het Deltaplan Agrarisch Waterbeheer (DAW). ${ }^{12}$ Het DAW is een initiatief van LTO Nederland en zal samen met de waterschappen en met betrokkenheid van de ministeries van Infrastructuur en Milieu en Economische Zaken, de provincies en drinkwatersector tot uitvoering worden gebracht. De samenwerking wordt aangestuurd door het Bestuurlijk Overleg Open Teelten en Veehouderij (BOOT), in opdracht van de Stuurgroep Water.

Het DAW geeft invulling aan de behoefte aan structuur, integraliteit en het leggen van verbindingen. Overheden, waterbeheerders en het agrarisch bedrijfsleven gaan een nauwe samenwerking aan. De ambitie is:

1. In 2021 is $80 \%$ van de resterende waterkwaliteitsproblemen op een motiverende en stimulerende wijze opgelost en in $2027100 \%$

2. In 2021 is de agrarische watervoorziening duurzaam door spaarzaam om te gaan met water op bedrijfsniveau, waterconservering op gebiedsniveau en een slimmere verdeling en buffering op rijksniveau, die aansluit bij de deltabeslissing die in 2014 wordt genomen

3. Door middel van gebiedsprocessen, nieuwe ruimtelijke instrumenten en innovatieve technieken wordt het agrarisch productiepotentieel op regionaal niveau met $2 \%$ per jaar vergroot.

Partners gaan voor een samenhangende aanpak, die een oplossing biedt voor de wateropgaven en een economisch sterkere land- en tuinbouw oplevert.

Voordelen voor de land- en tuinbouw zijn:

- LTO wil het KRW stroomgebiedbeheerplan 2016-2021 faciliteren door samen met overheden een effectieve aanpak te ontwikkelen die aansluit bij een duurzame landbouw.

- LTO wil de deltabeslissing zoetwater 2014 faciliteren door actief aan de slag te gaan met waterbesparing en conservering, ondersteund door onderzoek. Maatschappelijk verantwoord ondernemen op een wijze die de ontwikkeling van de sector ondersteunt.

- LTO wil ruimtelijke instrumenten ontwikkelen die de uitwerking van maatschappelijke opgaven koppelen aan landbouwontwikkeling.

Voordelen voor het waterbeheer zijn:

- Land- en tuinbouw, die $70 \%$ van het landelijke gebied beheren, denken en werken actief mee aan de wateropgaven via een gebiedsgerichte aanpak.

- Er wordt structuur aangebracht in versnipperde activiteiten, wat de efficiëntie ten goede komt en de realisatiekans vergroot.

- Er ontstaat een sterke en duurzame land- en tuinbouw, wat mede in het belang is van de overheid (economie, welvaart, voedselzekerheid).

Het BOOT heeft aangedrongen op concrete uitvoeringsmaatregelen om daarmee te voorkomen dat de partijen in de landbouwwaterwereld zich te veel beperken tot het voortschrijdende onderzoek en de implementatie van kansrijke maatregelen vertraging oploopt. Voorbeelden van maatregelen zijn:

\footnotetext{
${ }^{12}$ http://agrarischwaterbeheer.nl/system/files/documenten/pagina/brochure_daw_januari_2013.pdf
} 


\section{B4.1 Maatregelen Goede Landbouwpraktijk}

LTO heeft de ambitie om in 2020 de primaire productie duurzaam en maatschappelijk geaccepteerd te laten zijn. De LTO vakgroepen Akkerbouw en Melkveehouderij zijn bereid een waterparagraaf op te nemen in hun duurzaamheidscertificaat. Het certificaat moet het mogelijk maken om het peloton bij de kopgroep te laten aansluiten. De DAW themawerkgroepen worden gevraagd daartoe maatregelen aan te dragen en de regio's worden gevraagd deze in de relevante gebiedsprocessen te introduceren.

\section{B4.2 Beleidsonderzoek}

De programmering van het landbouwwateronderzoek loopt langs het kanaal van het Beleidsonderzoek van de ministeries I\&M en EZ, STOWA en het Landbouwpraktijkonderzoek van de sector. Enige afstemming is wenselijk. De DAW themawerkgroepen inventariseren de resultaten van de relevante onderzoeksrapporten en plaatsen de maatregelen op de groslijst met kansrijke implementeerbare landbouwmaatregelen. Daarnaast agenderen en adresseren de themawerkgroepen eventuele kennisvragen bij de onderzoeksprogrammering van het meest geëigende kanaal.

\section{B4.3 Blue Deals}

In navolging van de Green Deals sluiten partijen met de sectoren in de regio's convenanten waarin samenwerkingsafspraken SMART worden gemaakt. Inmiddels zijn goede voorbeelden bekend van landbouw en wateropgaven. Het BOOT heeft zelf op die manier met de LTO vakgroep Melkveehouderij afgesproken met voorrang de lozing van het perssap uit de kuilopslag te saneren. De ZLTO heeft met de regionale overheden afgesproken dat ze de goede ervaringen met gewasbeschermingsmiddelenmaatregelen in West Brabant met het project Schoon Water, uitrollen over de rest van haar werkgebied. LTO Noord is met RBO Rijn West een samenwerking aangegaan voor de aanpak van de nutriëntenbelasting in de Bollenstreek, het Veenweidegebied en de Droogmakerijen. De Stuurgroep Deltaprogramma Zoetwater Oost Nederland heeft met LTO Noord de droogtebestrijding in het Oostelijk zandgebied ter hand genomen en HDSR heeft met de NFO een convenant over het terugdringen van de emissies uit de fruitteelt gesloten. Deze voorbeelden verdienen navolging. Het regionale driehoeksoverleg wordt gevraagd om op deze manier de goede intenties en de gemaakte afspraken zo veel mogelijk vorm te geven in een Blue Deal.

\section{B4.4 Beleidsadviezen Deltaplan Zoetwater en Waterplannen 2015 - 2021}

De publieke participatie in de KRW en het Deltaprogramma houdt in dat de sector wordt uitgedaagd om oplossingsrichtingen te verkennen. Het DAW verkend in 2013 de mogelijkheden van de sector om daar in bij te dragen. Volgens het Nationaal Waterplan moeten polders bij droogte meer zelfvoorzienend zijn, moet de buffercapaciteit van de bodem beter worden benut en volgens het Meetnet Nutriënten Landbouwspecifieke Oppervlaktewateren en de gegevens uit de Bestrijdingsmiddelenatlas moet er in veel oppervlaktewateren een doelgat worden gedicht. In de DAW gebiedsprocessen worden de kansrijke opties en de oplossingsrichtingen verkent en wordt de aanpak opgenomen in de volgende generatie waterplannen die uiteindelijk door de Stuurgroep Water worden vastgesteld. 
LEI Wageningen UR Postbus 29703

2502 LS Den Haag

T 0703358330

E publicatie.lei@wur.nl

www.wageningenUR.nl/lei

Rapport

LEI 2016-033

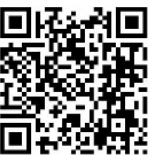

LEI Wageningen UR is een onafhankelijk, internationaal toonaangevend, sociaaleconomisch onderzoeksinstituut. De unieke data, modellen en kennis van het LEI bieden opdrachtgevers op vernieuwende wijze inzichten en integrale adviezen bij beleid en besluitvorming, en dragen uiteindelijk bij aan een duurzamere wereld. Het LEI maakt deel uit van Wageningen UR (University \& Research centre). Daarbinnen vormt het samen met het Departement Maatschappijwetenschappen van Wageningen University en het Wageningen UR Centre for Development Innovation de Social Sciences Group.

De missie van Wageningen UR (University \& Research centre) is 'To explore the potential of nature to improve the quality of life'. Binnen Wageningen UR bundelen 9 gespecialiseerde onderzoeksinstituten van stichting DLO en Wageningen University hun krachten om bij te dragen aan de oplossing van belangrijke vragen in het domein van gezonde voeding en leefomgeving. Met ongeveer 30 vestigingen, 6.500 medewerkers en 10.000 studenten behoort Wageningen UR wereldwijd tot de aansprekende kennisinstellingen binnen haar domein. De integrale benadering van de vraagstukken en de samenwerking tussen verschillende disciplines vormen het hart van de unieke Wageningen aanpak. 

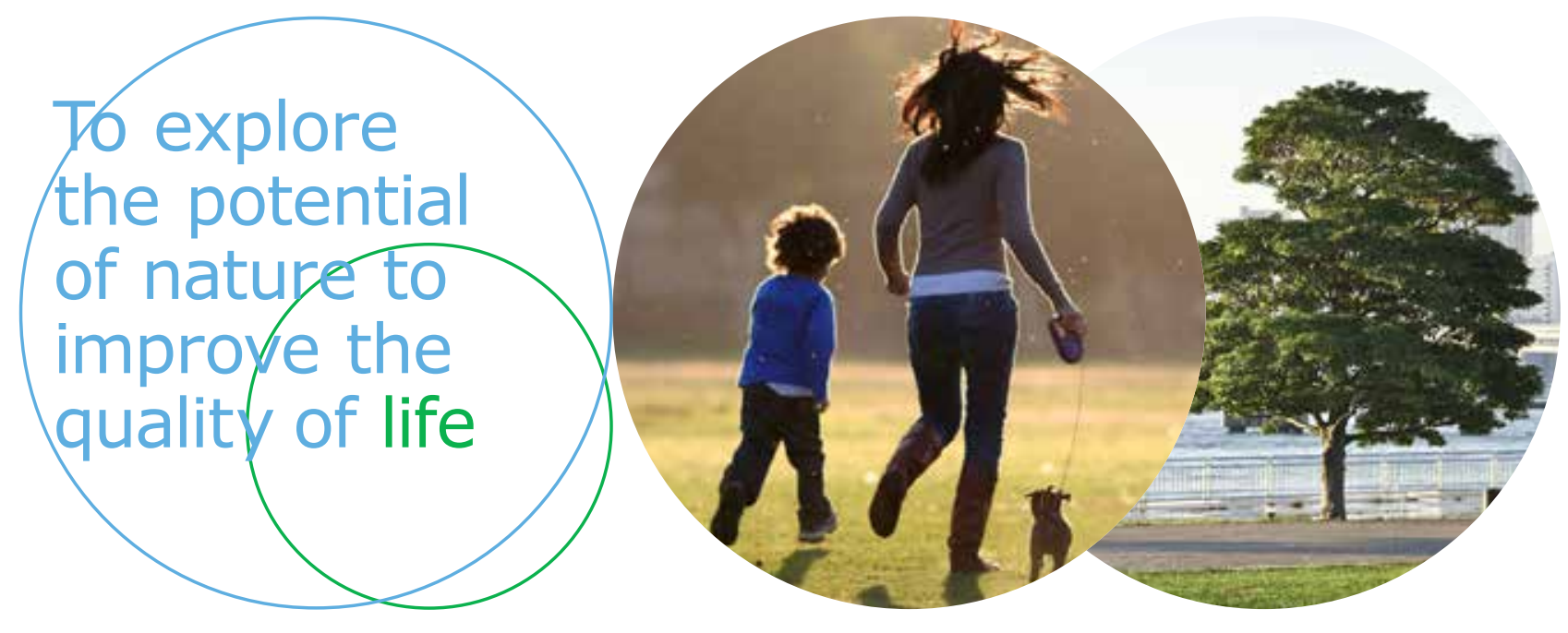

LEI Wageningen UR

Postbus 29703

2502 LS Den Haag

E publicatie.lei@wur.nl

www.wageningenUR.nl/lei

RAPPORT

LEI 2016-033

ISBN 978-94-6257-779-4
LEI Wageningen UR is een onafhankelijk, internationaal toonaangevend, sociaaleconomisch onderzoeksinstituut. De unieke data, modellen en kennis van het LEI bieden opdrachtgevers op vernieuwende wijze inzichten en integrale adviezen bij beleid en besluitvorming, en dragen uiteindelijk bij aan een duurzamere wereld. Het LEI maakt deel uit van Wageningen UR (University \& Research centre). Daarbinnen vormt het samen met het Departement Maatschappijwetenschappen van Wageningen University en het Wageningen UR Centre for Development Innovation van de Social Sciences Group.

De missie van Wageningen UR (University \& Research centre) is 'To explore the potential of nature to improve the quality of life'. Binnen Wageningen UR bundelen 9 gespecialiseerde onderzoeksinstituten van stichting DLO en Wageningen University hun krachten om bij te dragen aan de oplossing van belangrijke vragen in het domein van gezonde voeding en leefomgeving. Met ongeveer 30 vestigingen, 6.500 medewerkers en 10.000 studenten behoort Wageningen UR wereldwijd tot de aansprekende kennisinstellingen binnen haar domein. De integrale benadering van de vraagstukken en de samenwerking tussen verschillende disciplines vormen het hart van de unieke Wageningen aanpak. 